Prepared in cooperation with the Florida Department of Agricultural and Consumer Services

\title{
Water Withdrawals, Uses, and Trends in Florida, 2015
}

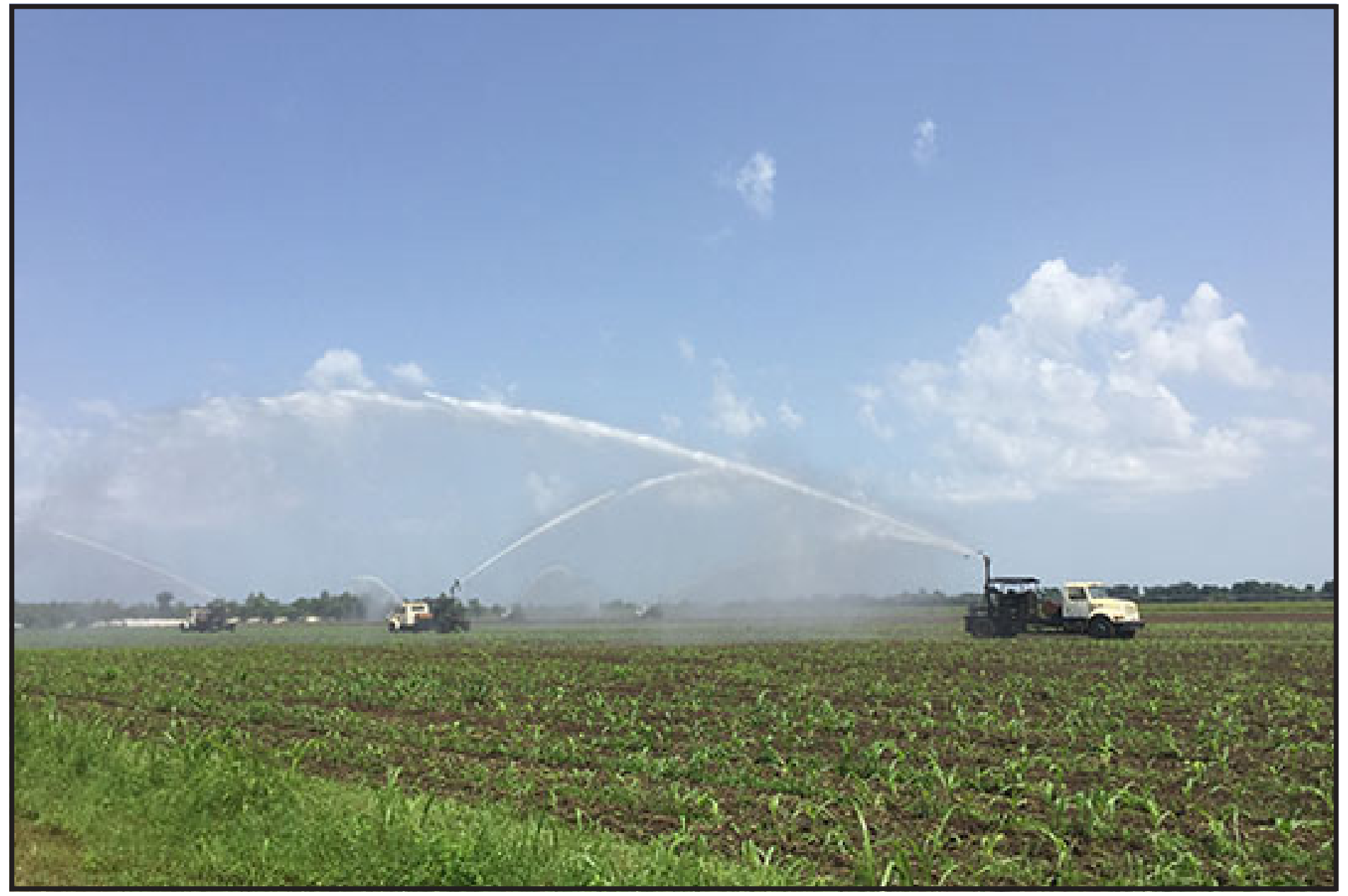

Scientific Investigations Report 2019-5147 
Cover. Photograph of portable high-volume guns used for irrigation, Miami-Dade County, Florida. Photograph by Richard L. Marella, U.S. Geological Survey. 


\section{Water Withdrawals, Uses, and Trends in Florida, 2015}

By Richard L. Marella

Prepared in cooperation with the Florida Department of Agricultural and Consumer Services

Scientific Investigations Report 2019-5147 


\title{
U.S. Department of the Interior DAVID BERNHARDT, Secretary
}

\author{
U.S. Geological Survey \\ James F. Reilly II, Director
}

\section{U.S. Geological Survey, Reston, Virginia: 2020}

For more information on the USGS - the Federal source for science about the Earth, its natural and living resources, natural hazards, and the environment-visit https://www.usgs.gov or call 1-888-ASK-USGS.

For an overview of USGS information products, including maps, imagery, and publications, visit https://store.usgs.gov.

Any use of trade, firm, or product names is for descriptive purposes only and does not imply endorsement by the U.S. Government.

Although this information product, for the most part, is in the public domain, it also may contain copyrighted materials as noted in the text. Permission to reproduce copyrighted items must be secured from the copyright owner.

Suggested citation:

Marella, R.L., 2020, Water withdrawals, uses, and trends in Florida, 2015: U.S. Geological Survey Scientific Investigations Report 2019-5147, 52 p., https://doi.org/10.3133/sir20195147.

Associated data for this publication:

Marella, R.L. and Dixon, J.F., 2018, Data tables summarizing the source-specific estimated water withdrawals in Florida by water source, category, county, and water management district, 2015: U.S. Geological Survey data release, https://doi.org/10.5066/F7N29W5M.

ISSN 2328-0328 (online) 


\section{Acknowledgments}

The author gratefully acknowledges the Florida Department of Agricultural and Consumer Services for its cooperation in the U.S. Geological Survey statewide Water-Use Program and extends a special thanks to S. Ray Scott and Yesenia Escabano from the Office of Agricultural Water Policy, who provided program support for this project. In addition, appreciation is extended to each of the five water management districts in Florida for providing the necessary data compiled in this report. Specific appreciation is extended to Beth Holister and Kenneth Friedman at the Northwest Florida Water Management District, Tammy Bader at the St. Johns River Water Management District, James Harmon and Nathan Kennedy at the South Florida Water Management District, John Ferguson at the Southwest Florida Water Management District, and Amy Brown and Eliza Breder at the Suwannee River Water Management District.

Appreciation is also extended to the many utility operators, plant managers, and individuals who provided data and technical guidance vital to the completion of this report. These contributors include staff from the following companies and government agencies: Florida Power and Light Company, Duke Energy, Gainesville Regional Utilities, Gulf Power Company la subsidiary of Southern Company), Jacksonville Electric Authority, Lakeland Electric and Water, Miami-Dade County Water and Sewer Department, Orlando Utilities Commission, Seminole Electric Cooperative, Tampa Bay Water, Tampa Electric Company, and the City of Tallahassee. 



\section{Contents}

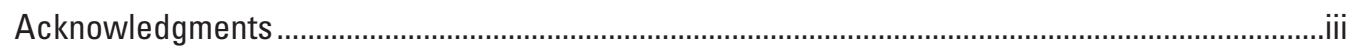

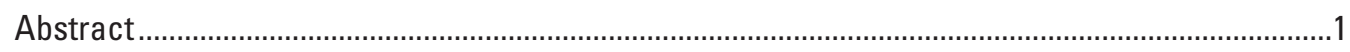

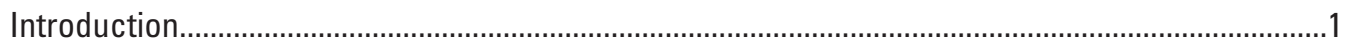

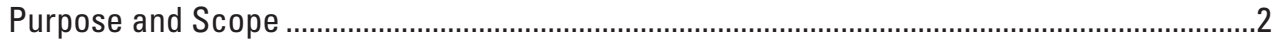

Previous Investigations...........................................................................................................

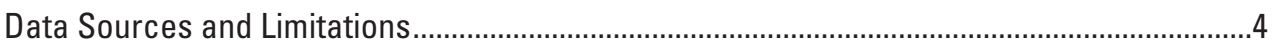

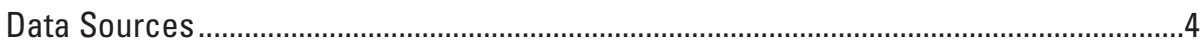

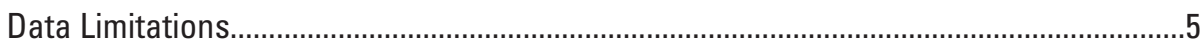

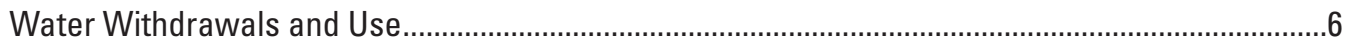

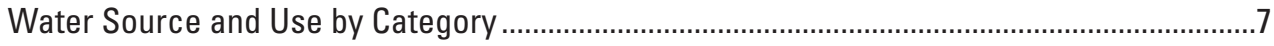

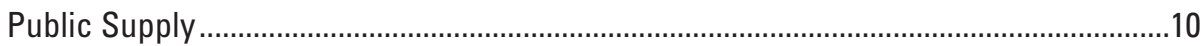

Domestic Self-Supplied .......................................................................................17

Commercial-Industrial-Mining Self-Supplied ................................................................19

Agricultural Self-Supplied (Irrigation and Nonirrigation) ..............................................21

Recreational-Landscape Irrigation ..............................................................................24

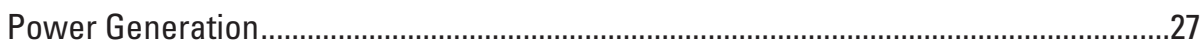

Water Source, Use, and Trends by Water Management District..........................................29

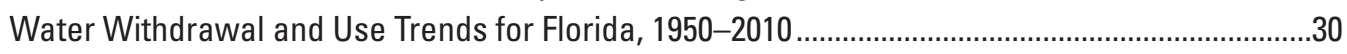

Summary

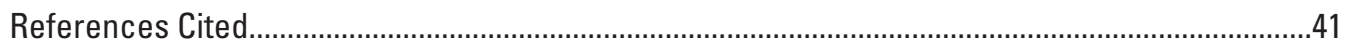

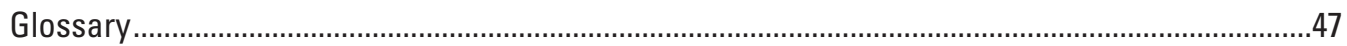

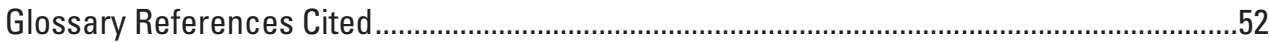

\section{Figures}

1. Graph showing historical and projected population of Florida, 1950-2030 .....................2

2. Map showing counties and water management districts in Florida .................................3

3. Pie chart showing total water withdrawals in Florida by source, 2015............................7

4. Pie chart showing freshwater withdrawals in Florida by category and water

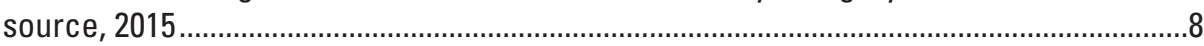

5. Map showing approximate areal extent throughout which principal aquifers in Florida are the primary source of groundwater, and quantity of groundwater

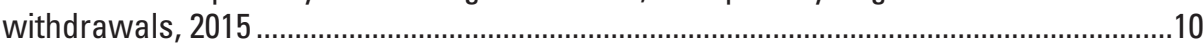

6. Map showing general location of hydrologic units in Florida and fresh groundwater and surface-water withdrawals within these units, 2015.........................12

7. Pie chart showing public-supply water-use deliveries in Florida, 2015 .........................14

8. Graph showing historical public-supply gross and domestic per capita water use in Florida, 1950-2015.

9. Graph showing historical public-supply freshwater withdrawals in Florida by source, 1950-2015.

10. Graph showing historical domestic self-supplied groundwater withdrawals in Florida, 1950-2015.

11. Pie chart showing commercial-industrial-mining self-supplied freshwater use in Florida by major industrial type, 2015

12. Graph showing historical commercial-industrial-mining self-supplied freshwater withdrawals in Florida by source, 1950-2015. 
13. Graph showing historical agricultural self-supplied freshwater withdrawals in Florida by source, 1950-2015.

14. Graph showing historical agricultural acreage in Florida for selected crops, 1970-2016.

15. Graph showing historical recreational-landscape irrigation freshwater withdrawals in Florida by source, 1985-2015...

16. Graph showing historical power-generation water withdrawals in Florida by source, 1950-2015.

17. Graph showing total population and population served by public supply in Florida by water management district, 2015

18. Pie chart showing freshwater withdrawals in Florida by water management district, 2015 .

19. Graph showing freshwater and saline-water withdrawals in Florida by water management district, 2015

20. Graph showing historical freshwater withdrawals (excluding power generation) in Florida by water management district, 1975-2015.

21. Graph showing historical freshwater withdrawals by water-use category in Florida by water management district, 1975-2015

22. Graph showing historical public-supply gross per capita water use in Florida by water management district, 1975-2015

23. Graph showing the number of permits issued by the county health departments for private lawn irrigation wells, 1995-2015.

24. Graph showing freshwater withdrawals for agricultural self-supplied and public-supply use with statewide average annual rainfall in Florida, 1980-2015

25. Graph showing historical public-supply withdrawals in Florida, 1975-2015

26. Graph showing historical total population, freshwater, and saline-water withdrawals in Florida, 1950-2015

27. Graph showing historical freshwater withdrawals in Florida by source, 1950-2015.

28. Graph showing historical freshwater withdrawals in Florida by selected water-use category, 1975-2015

\section{Tables}

1. Total water withdrawals by in Florida by category, 2015 .6

2. Total water withdrawals by in Florida by county, 2015.

3. Total groundwater withdrawals by principal aquifer in Florida by county, 2015..............11

4. Public-supply population, water use, withdrawals, transfers, and treated water in Florida by county, 2015.

5. Estimated public-supply water use (deliveries), and per capita use in Florida by county, 2015

6. Domestic self-supplied population and water withdrawals in Florida by county, 2015

7. Commercial-industrial-mining self-supplied water withdrawals in Florida by county, 2015

8. Agricultural self-supplied water withdrawals by in Florida by county, 2015.................23

9. Recreational-landscape irrigation water withdrawals in Florida by county, 2015 ..........25

10. Power generation water withdrawals in Florida by county, 2015 ..................................28

11. Water withdrawals by category in Florida by water management district, 2015 ............31 
12. Historical population and water withdrawals in Florida by water source in Florida, 1950-2015. .37

13. Historical freshwater withdrawals in Florida by category, 1970-2015

\section{Conversion Factors}

U.S. customary units to International System of Units

\begin{tabular}{|c|c|c|}
\hline Multiply & By & To obtain \\
\hline \multicolumn{3}{|c|}{ Length } \\
\hline inch (in.) & 2.54 & centimeter $(\mathrm{cm})$ \\
\hline inch (in.) & 25.4 & millimeter (mm) \\
\hline mile (mi) & 1.609 & kilometer (km) \\
\hline \multicolumn{3}{|c|}{ Area } \\
\hline acre & 4,047 & square meter $\left(\mathrm{m}^{2}\right)$ \\
\hline acre & 0.4047 & hectare (ha) \\
\hline acre & 0.4047 & square hectometer $\left(\mathrm{hm}^{2}\right)$ \\
\hline acre & 0.004047 & square kilometer $\left(\mathrm{km}^{2}\right)$ \\
\hline square mile $\left(\mathrm{mi}^{2}\right)$ & 259.0 & hectare (ha) \\
\hline square mile $\left(\mathrm{mi}^{2}\right)$ & 2.590 & square kilometer $\left(\mathrm{km}^{2}\right)$ \\
\hline \multicolumn{3}{|c|}{ Flow rate } \\
\hline gallon per day (gal/d) & 0.003785 & cubic meter per day $\left(\mathrm{m}^{3} / \mathrm{d}\right)$ \\
\hline million gallons per day (Mgal/d) & 0.04381 & cubic meter per second $\left(\mathrm{m}^{3} / \mathrm{s}\right)$ \\
\hline \multicolumn{3}{|c|}{ Energy } \\
\hline gigawatthour (GWh) & $2.778 \times 10^{-13}$ & joule (J) \\
\hline
\end{tabular}

\section{Supplemental Information}

Concentrations of chemical constituents in water are given in milligrams per liter (mg/L)

\section{Abbreviations}

FDACS

FDEP

FSAID

NWFWMD

SFWMD

SJRWMD

SRWMD

SWFWMD

USDA

USGS

WAUSP

WMD
Florida Department of Agriculture and Consumer Services

Florida Department of Environmental Protection

Florida Statewide Agricultural Irrigation Demand

Northwest Florida Water Management District

South Florida Water Management District

St. Johns River Water Management District

Suwannee River Water Management District

Southwest Florida Water Management District

U.S. Department of Agriculture

U.S. Geological Survey

Water Availability and Use Science Program

water management district 



\title{
Water Withdrawals, Uses, and Trends in Florida, 2015
}

\author{
By Richard L. Marella
}

\section{Abstract}

In 2015, the total amount of water withdrawn in Florida was estimated to be 15,319 million gallons per day (Mgal/d). Saline water accounted for $9,598 \mathrm{Mgal} / \mathrm{d}$ (63 percent) and freshwater accounted for 5,721 Mgal/d (37 percent) of the total. Groundwater accounted for 3,604 Mgal/d (63 percent) of freshwater withdrawals and surface water accounted for the remaining 2,117 Mgal/d (37 percent). Surface-water sources accounted for $9,401 \mathrm{Mgal} / \mathrm{d}$ (98 percent) of the saline-water withdrawals, and groundwater sources accounted for the remaining $198 \mathrm{Mgal} / \mathrm{d}$ (2 percent). The majority of groundwater withdrawals (almost 62 percent) in 2015 were from the Floridan aquifer system, which is used throughout most of the State while the majority of fresh surface-water withdrawals (52 percent) occurred in the Southern Florida Subregion, a hydrologic unit that includes Lake Okeechobee and canals in the Everglades Agricultural Area. Groundwater provided drinking water (public supplied and self-supplied) for 18.324 million people (92 percent of Florida's population), and fresh surface water provided drinking water for 1.491 million people ( 8 percent).

Overall, public supply accounted for 39 percent of the total freshwater withdrawals (ground and surface) and 53 percent of groundwater withdrawals, followed by agricultural self-supplied uses, which accounted for 37 percent of the total freshwater withdrawals and 28 percent of groundwater withdrawals. Other self-supplied groundwater withdrawals include commercial-industrial-mining self-supplied ( 8 percent), recreational-landscape irrigation and domestic self-supplied (5 percent each), and power generation (less than 1 percent). Agricultural self-supplied withdrawals accounted for 51 percent of fresh surface-water withdrawals, followed by power generation (19 percent), public supply (15 percent), recreational-landscape irrigation (10 percent), and commercial-industrial-mining self-supplied (5 percent).

In 1975, agricultural water withdrawals accounted for 43 percent of the total freshwater withdrawals, followed by power generation ( 24 percent) and public supply (17 percent). By 2000, agricultural withdrawals increased to 48 percent of the total freshwater withdrawals, followed by public supply (30 percent). For 2015, agricultural self-supplied decreased to 37 percent of total freshwater withdrawals, and was surpassed by public supply at 39 percent. Over the 40-year period between 1975 and 2015, increases in freshwater withdrawals caused by large gains in population and the expansion of irrigated acreage were offset by decreases in water used for power generation and commercial-industrial-mining withdrawals. Since 2000, however, irrigated acreage has decreased statewide because of crop disease, storm damage, and urbanization. This decline, coupled with large gains in water conservation measures in the farming industry, has led to agricultural withdrawals in Florida being less than public-supply withdrawals for the first time since water-use data were first reported in 1965.

\section{Introduction}

Water is among Florida's most valued resources. The State has more than 1,700 streams and rivers, 7,800 freshwater lakes, 700 springs, 11 million acres of wetlands, and underlying aquifers yielding substantial quantities of freshwater necessary for human and environmental needs (Fernald and Purdum, 1998). Although renewable, these water resources are limited, and continued growth in population, tourism, and agriculture will place increased demands on them.

The population of Florida totaled 19.815 million in 2015 (University of Florida, 2015a), ranking the State third in the Nation, behind California and Texas (U.S. Census Bureau, 2016, table 1). This population represents an increase of about 615 percent (17.045 million) from the 1950 population of 2.77 million (Dietrich, 1978), and a 5-percent increase from the 2010 population of 18.801 million (fig. 1; University of Florida, 2015a). Florida's population is projected to reach nearly 21.5 million by 2020 and exceed 24.0 million by 2030 (fig. 1; Rayer and Wang, 2018). In addition to the State's resident population, slightly more than 106.6 million people visited Florida in 2015 (Visit Florida, 2018). Freshwater will remain a vital resource for Florida's residents and visitors as population and tourism continue to increase statewide.

The agricultural sector in Florida depends heavily on the State's water resources. In 2015, Florida produced nearly two-thirds ( 60 percent) of the total citrus production in the United States and ranked 11th in the Nation in total agricultural cash receipts (Florida Department of Agriculture and Consumer Services, 2017). Agriculture is expected to remain important, because the State's subtropical climate fosters the cultivation and growth of a wide variety of crops, and demands for locally produced food from the growing population have remained constant (Mulkey and 


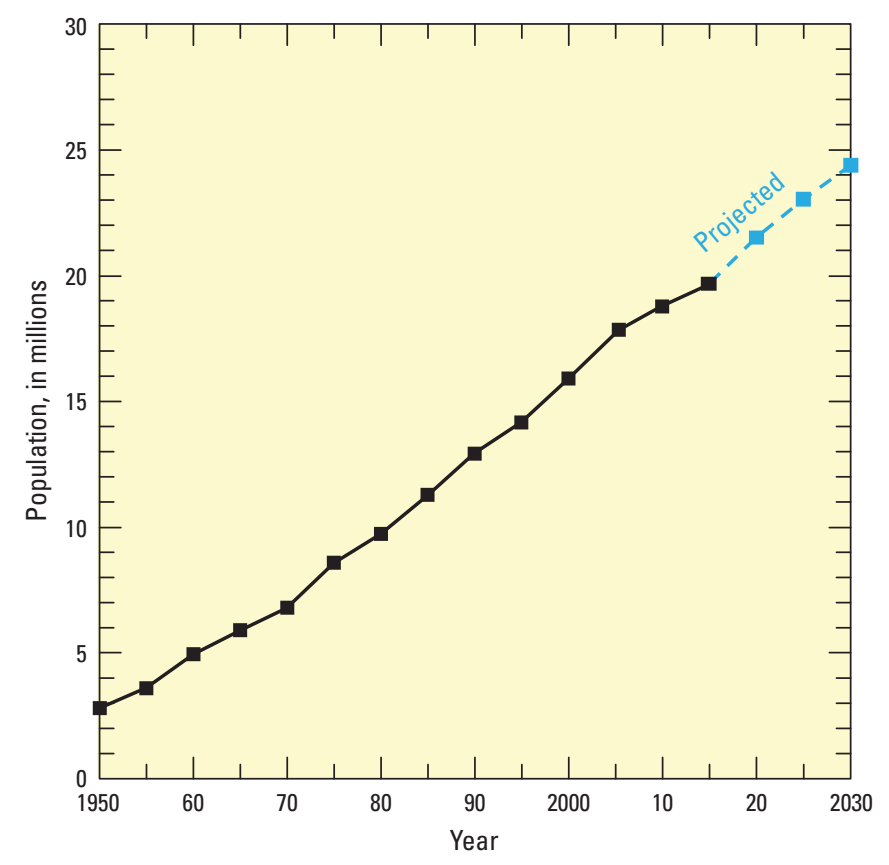

Figure 1. Historical and projected population of Florida, 1950-2030. From Dietrich (1978), University of Florida (2015a), and Rayer and Wang (2018).

Clouser, 1990). Accurate and reliable information concerning the amount of water required to support future agriculture is essential to the development of the State economy and vital to the well-being of its residents and visitors.

Estimates of current water use and historical trends in Florida have been compiled by the U.S. Geological Survey (USGS), in cooperation with the Florida Department of Agricultural and Consumer Services (FDACS), and in collaboration with the Northwest Florida Water Management District (NWFWMD), St. Johns River Water Management District (SJRWMD), South Florida Water Management District (SFWMD), Southwest Florida Water Management District (SWFWMD), Suwannee River Water Management District (SRWMD), and the Florida Department of Environmental Protection (FDEP). This coordinated effort provides the data and information needed to estimate future water needs and plan future resource management in Florida.

\section{Purpose and Scope}

The purpose of this report is to provide detailed information about the quantities of water withdrawn in 2015 in the State of Florida and increase understanding about water-use trends between 1950 and 2015. Overall, the report provides a basis for summarizing water withdrawals, understanding water use, and estimating future water needs. Water-use estimates for Florida are presented in this report by category, county, water source (surface water and groundwater, including principal aquifers), and water management district (WMD).

Data presented on water withdrawals in Florida were classified as public supply (including deliveries) and self-supplied. Self-supplied withdrawals were further subdivided into the following water-use categories: domestic (private household use), commercial-industrial-mining, agricultural (including irrigation and nonirrigation uses), recreational-landscape irrigation (including golf course irrigation), and power generation. Data are not presented for instream uses (nonwithdrawal), such as hydroelectric power generation, navigation, water-based recreation, propagation of fish and wildlife, and dilution and conveyance of liquid or solid waste. This report does not include specific data on the amount of water discharged from wastewater-treatment facilities, septic tanks, or retention ponds.

Within each withdrawal category, data are presented by source (groundwater or surface water and freshwater or saline water), and trends in historical water use are described. Data also are presented by county and WMD (fig. 2) for each water-use category. Additional information about water use can be obtained by contacting the USGS Caribbean-Florida Water Science Center (CFWSC) offices in Lutz, Orlando, or Davie, or by visiting the CFWSC Water Use website at https://www.usgs.gov/centers/car-fl-water/science/water-use.

\section{Previous Investigations}

This report is the 13th in a series of reports documenting the results of water-use investigations in Florida. Statewide water-use data for Florida were published for 1965 and 1970 (Pride, 1973, 1975); for 1975, 1977, and 1980 (Leach, 1978, 1983; Leach and Healy, 1980); and for 1985, 1990, 1995, 2000, 2005, 2010, and 2012 (Marella, 1988, 1992, 1999, 2004, 2009, 2014, 2015). These 12 reports include assessments of all water uses in Florida, by county, and withdrawal categories (such as public and self-supplied withdrawals). Historical water-use data for the State and each county for all freshwater withdrawals by category between 1965 and 2015 are available from the CFWSC, Historical Water-Use in Florida website at https://www.usgs.gov/centers/car-fl-water/ science/historical-water-use-florida?qt-science_center objects $=0 \#$ qt-science_center_objects.

Prior to 1965, State water-use data were published only at the national level. Nationwide summaries of water-use data were published for 1950, 1955, and 1960 (MacKichan, 1951, 1957; MacKichan and Kammerer, 1961). These reports include detailed water-use data at the State level but do not include water-use data for counties. Nationwide summaries, including data for Florida, also were published by the USGS for 1965, 1970, and 1975 (Murray, 1968; Murray and Reeves, 1972, 1977); for 1980, 1985, 1990, and 1995 (Solley and others, 1983, 1988, 1993, 1998); for 2000 (Hutson and others, 2004); for 2005 (Kenny and others, 2009); for 2010 (Maupin and others, 2014); and for 2015 (Dieter and others, 2018a). National and State data for 2015 and prior years are available from the USGS Water Use in the United States website at https://www.usgs.gov/mission-areas/waterresources/science/water-use-united-states?qt-science_center_ objects $=0 \#$ qt-science_center_objects. 


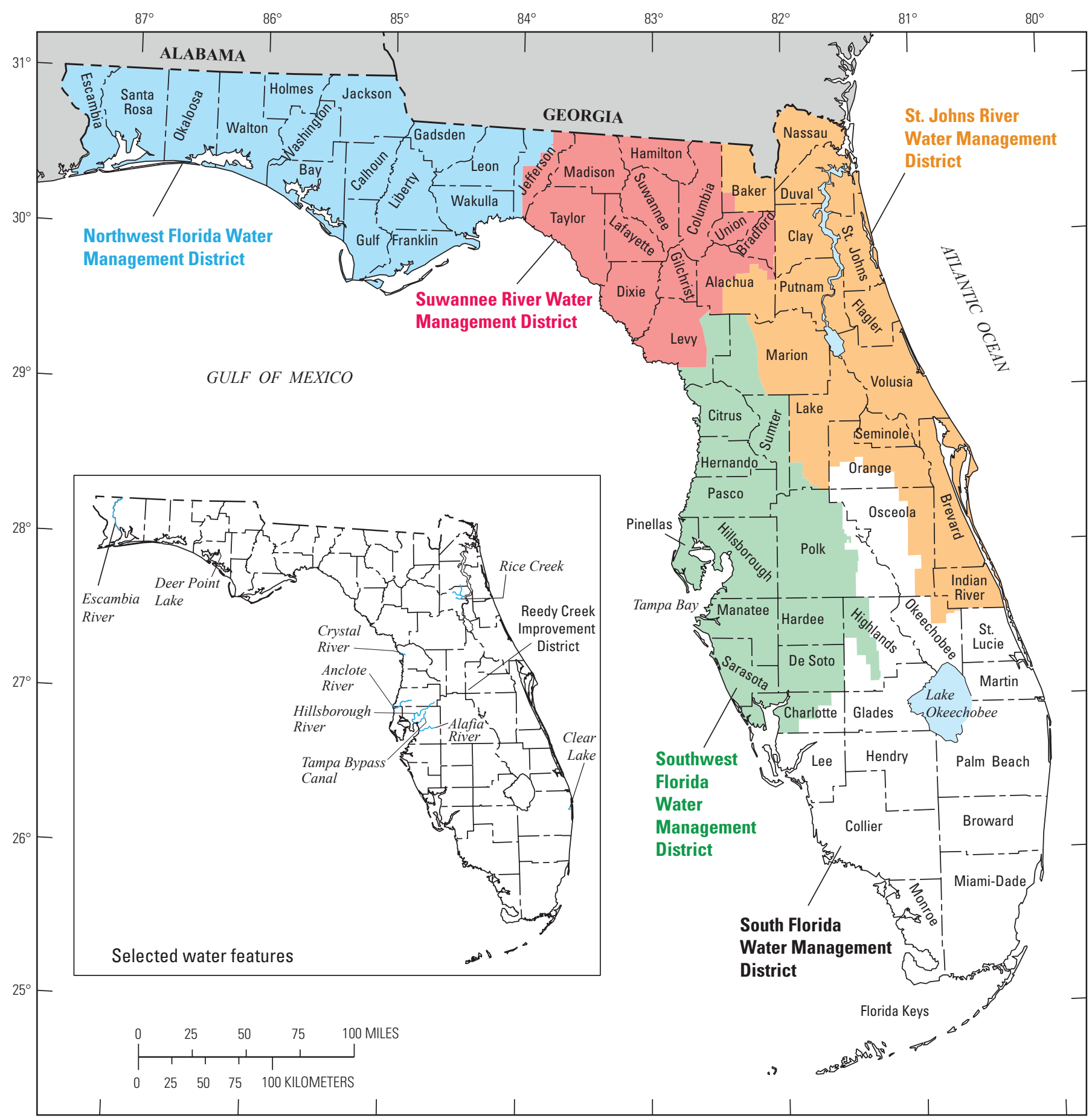

Base modified from U.S. Geological Survey Florida State base map, 1:500,000, 1974

Figure 2. Counties and water management districts in Florida. From Fernald and Purdum (1998).

Additional water-use reports for Florida were published by selected WMDs between 1975 and 2015. The SJRWMD and SWFWMD have published annual water-use reports since 1979; the SFWMD published an annual water-use report in 2014, its first annual report since 1980; and the NWFWMD and SRWMD intermittently published reports between 1976 and 1985. Detailed water-use data for 2015 were published by the SFWMD (Harmon and others, 2017) and the SWFWMD
(Ferguson, 2016), and a fact sheet summarizing water use for 2015 was published by the SJRWMD (St. Johns River Water Management District, 2016). Historical freshwater-withdrawal data for each WMD between 1975 and 2015 are available from the USGS CFWSC Historical Water-Use in Florida website at https://www.usgs.gov/centers/ car-fl-water/science/historical-water-use-florida?qt-science center_objects $=0 \# q \mathrm{qt}-\mathrm{science}$ _center_objects. 
Water Withdrawals, Uses, and Trends in Florida, 2015

\section{Data Sources and Limitations}

As part of the USGS Water Availability and Use Science Program (WAUSP), water-use data are compiled for each State every 5 years. Compilations are based on data collected by the five Florida WMDs, and sources are discussed in detail in the Data Sources section herein. Data for 2015 were compiled under nationwide guidelines specified by the USGS (Bradley, 2017). Data for each State are reported by major water-use category and county; some States also report by hydrologic unit (basin) and aquifer. Water-use data for Florida were compiled through a cooperative agreement with the FDACS, Office of Agricultural Water Policy, as part of the 2015 USGS National Water Cooperative Program. The data sources and limitations are listed below.

\section{Data Sources}

Public-supply, domestic self-supplied, and commercialindustrial-mining self-supplied-Water withdrawal totals for public-supply, domestic self-supplied and commercialindustrial-mining self-supplied uses were obtained from publications or spreadsheets provided by each WMD. For the SJRWMD, SFWMD, and SWFWMD, withdrawals for each category for the counties within each district were obtained from the following reports: "2015 Survey of Estimated Annual Water Use for the St. Johns River Water Management District" (St Johns River Water Management District, 2016), "South Florida Water Management District 2015 Estimated Water Use Report" (Harmon and others, 2017), and "Southwest Florida Water Management District 2015 Estimated Water Use Report" (Ferguson, 2016). For the NWFWMD and SRWMD, withdrawal totals for these categories were obtained from spreadsheets compiled by the districts as part of their water-supply planning efforts (Beth Hollister, Northwest Florida Water Management District, written commun., March 12, 2017, and Amy Brown, Suwannee River Water Management District, written commun., March 12, 2017, respectively). Public-supply population-served estimates for the counties within each WMD were also obtained from these sources. However, published population-served values for the SWFWMD were modified to remove seasonal population estimates from the county totals to be consistent with the population served estimates for the counties in the other four WMDs. Seasonal population estimates were also adjusted for the self-supplied population totals in the SWFWMD.

Agricultural self-supplied -Water withdrawal totals for agricultural self-supplied uses were obtained from publications or spreadsheets provided by each WMD. For the SJRWMD, SFWMD, and SWFWMD, withdrawals for each category for the counties within each district were obtained from the published WMD reports (Ferguson, 2016; St Johns River Water Management District, 2016; Harmon and others, 2017). Water withdrawal totals for agricultural self-supplied uses for the counties within the NWFWMD and the SRWMD were estimated by the USGS and the WMD using irrigated acreage multiplied by an application rate (usually in inches per acre) for selected crop types. Irrigated acreage totals by crop type were obtained for the counties within these WMDs from recently completed irrigated land-use inventories for the counties in the SRWMD (Marella and others, 2016), Jackson, Calhoun, and Gadsden Counties (Marella and Dixon, 2015), and Escambia, Santa Rosa, and Okaloosa Counties (Marella and others, 2017). Irrigated acreage totals for the remaining unmapped counties within the NWFWMD (Bay, Holmes, Leon, Liberty, Walton, Wakulla, and Washington) were obtained from the Balmoral Group (Balmoral Group, 2016; Daniel Dourte, Balmoral Group, written commun., April 30, 2017). The acreage for these selected crops within these WMDs was multiplied by an application rate provided by the Balmoral Group (Daniel Dourte, Balmoral Group, written commun., April 30, 2017).

The agricultural self-supplied category also includes withdrawals for livestock and aquaculture (fish farming). Livestock and fish farming withdrawal estimates for the SWFWMD and SFWMD were obtained from the published WMD reports (Ferguson, 2016; Harmon and others, 2017). For the counties within the NWFWMD and SRWMD, estimates for fish-farming water withdrawals were obtained from the WMDs' consumptive water-use permits or obtained from information provided by the USGS (Lovelace, 2009a; Angela Collier, U.S. Geological Survey written commun., March 24, 2017) and withdrawal values for livestock were obtained from the USGS (Lovelace, 2009b). No 2015 withdrawal estimates for livestock were made or published in this report for the counties within the SJRWMD.

Recreation-landscape irrigation self-supplied -Water withdrawal totals for self-supplied recreation-landscape irrigation were obtained from publications or spreadsheets provided by each WMD. For the SJRWMD, SFWMD, and SWFWMD, withdrawals for each category for the counties within each district were obtained from the following WMD reports: Ferguson (2016), St Johns River Water Management District (2016), and Harmon and others (2017). Water withdrawal totals for recreation-landscape irrigation for the counties within the NWFWMD were obtained from a spreadsheet provided by the district (Beth Hollister, Northwest Florida Water Management District, written commun., March 12, 2017), and totals for those counties within the SRWMD were compiled by the USGS and the WMD using irrigated acreage by county for this category from 2010 multiplied by an application rate for grass/hay provided by the Balmoral Group (Daniel Dourte, Balmoral Group, written commun., April 30, 2017).

Power generation self-suppled-Self-supplied water withdrawals for power generation (including power-generation totals) were obtained directly from email correspondence with many of the power companies or producers across the State. This included Covanta, Duke Energy, Florida Municipal Power Company, Florida Power and Light, Gainesville Regional Utilities, Gulf Power Company, Hardee Power Partners, Jacksonville Electric Authority, City of Kissimmee, Lakeland Electric and Water, Orlando Utilities Commission, Seminole Electric, the City of Tallahassee, Vandolah Power 
Company, Wheelabrator Technologies, and a few other small power facilities. In addition, some withdrawal totals were also obtained from spreadsheets obtained from the five WMDs, and some power generated totals were obtained from the Energy Information Administration database of the U.S. Department of Energy (Melissa Harris, U.S. Geological Survey written commun., February 8, 2017).

\section{Aquifer withdrawals -Estimates of groundwater}

withdrawals by aquifer were made for each use category. For public supply, commercial-industrial-mining self-supplied, and power generation, information about the primary aquifer used for each well field or facility was obtained from permits in the WMD consumptive water-use permit files or from previous years' data. Estimates were made for domestic self-supplied, agricultural, and recreational-landscape irrigation withdrawals by using information obtained from selected groundwater studies conducted by the USGS or the WMDs throughout the State over the past 25 years that yielded detailed estimates of withdrawals for selected aquifers in specific counties. Other sources include information obtained from local agencies (county health departments) that regulate well construction or consumptive use. For some counties having little or no information, estimates were made by assuming that 90 percent of water withdrawals were from the primary aquifer used for public supply, and the remaining 10 percent were from the local water table or shallow aquifer.

\section{Data Limitations}

Reported values-Water-use values presented in this report are estimates of the amount of water withdrawn and do not represent actual quantities of water permitted or allocated. Water withdrawals and water-use data presented in this report represent the average daily quantities used, calculated from monthly totals or derived from annual totals, and are expressed in million gallons per day. Water-use values presented in the tables are reported to two decimal places (with a few exceptions) or to the nearest 10,000 gallons per day (gal/d). Water-use values in the report text are rounded to the nearest million gallons per day, and percentages are rounded. Population values presented in the text are rounded to the thousands (three decimal places) but presented as whole numbers within the tables. Water-use amounts and percentages are rounded up or down such that individual values are consistent with totals. For example, the values 9,400.54 and 197.66 sum to 9,598.20; however, when rounded, 9,401 and 198 do not sum to 9,598. In this case, the smallest of the two values totaled $(9,400.54)$ is rounded down $(9,400)$ such that the total is consistent with the sum of rounded-off and rounded-down values. In another example, the sum of rounded-off percentages sum to 99 percent, rather than 100 percent. In this case, the individual value that was not rounded up but had the largest remainder (such as 14.45 , which has a remainder of 0.45 ) is chosen to be rounded up so that all rounded-off values total to 100 percent.

Accuracy-The accuracy of water-use values varies by category; public-supply, commercial-industrial-mining self-supplied, and power generation values tend to be more accurate than values for other categories because public suppliers and nearly all commercial, industrial, mining, and power generation users meter or record their usage and submit the data to an appropriate agency (FDEP or WMD). Even though a large number of irrigation users (agriculture, recreation, and landscape) across Florida meter, record, and submit their usage, this practice is not comprehensive. Therefore, withdrawal totals for these categories are most often estimated by using irrigated acreage totals multiplied by a calculated application rate per crop type. However, the reported metered withdrawal volumes are often used to determine or help verify the application rate used to calculate the irrigation water withdrawal totals. Water withdrawals for self-supplied domestic use are also not metered; therefore, this category is estimated. In addition, because little or no information is available on the thousands of private lawn irrigation wells across the State, the water withdrawn by these users is unaccounted for in this report.

Changes in accuracy - Overall, water withdrawal totals for 2015 should be more accurate than those computed for previous years. Since water-use data were published in 1975, additional data sources have become available, consumptive water-use permitting by all WMDs went into effect in the early 1980s, and several irrigation models were developed specifically for Florida's climate to calculate a better crop application rate or coefficient (Smajstrla, 1990; Southwest Florida Water Management District, 1992), which provided the ability to estimate irrigation application rates on a field level. Over the past 10-15 years, however, additional changes have occurred in water-use knowledge and data collection that are believed to increase the accuracy of reported totals. Some of these changes include

- The development of water-supply planning at each WMD that includes a need for water-supply data and a full-time staff devoted to developing water demand projections. In previous years, the USGS, with assistance from WMD staff, collected and compiled much of the withdrawal totals for several WMDs; however, for the 2015 report, the USGS collected very little raw data and instead was provided with county and category totals by the WMDs. To further emphasize this point, the SFWMD published a 2014 water-use report (Harmon, 2016), their first annual water use report since 1980. Both the NWFWMD and SRWMD plan to publish annual reports or summaries in the near future (Beth Hollister, Northwest Florida Water Management District, written commun., March 12, 2017, and Amy Brown, Suwannee River Water Management District, written commun., March 12, 2017, respectively).

- The WMDs' effort to collect withdrawal data (compliance) through their consumptive water-use permits and make such data available to the public through their ePermitting websites. This web portal provides access to withdrawal records, by users, that were in paper form in previous years or were simply not accessible. 
- The development of the Florida Statewide Agricultural Irrigation Demand (FSAID) model, which was created by the FDACS Office of Agricultural Water Policy to provide consistent statewide estimates of agricultural water demands in Florida. Through this FSAID model, more accurate irrigated acreage totals were developed through an ongoing county field verification project with the USGS. The FSAID project also provides a better application rate per crop type by using existing metered irrigation pumpage records from the WMDs to verify the estimated application rates (Balmoral Group, 2011). Estimates of agricultural irrigation water withdrawals for this report are based on a crop application rate multiplied by the irrigated acreage for selected crop types.

- Additional resource-planning staff, available data sources, and technology improvements in all agencies over the past $10-15$ years, which collectively have increased the accuracy of water-use data statewide.

Published differences - Water-use data published in this report may not be identical to the water-use data published by the SJRWMD, SFWMD, and the SWFWMD because of differences in data-collection procedures, category definitions, and methodologies. For example, saline surface-water withdrawals for once-through cooling at several powerplants are not presented in the WMDs' reports but are provided in this report. In addition, some values in this report may differ from those presented by county in the USGS data release of estimated use of water in the United States county-level data for 2015 (Dieter and others, 2018b) and those published in the national report of the estimated use of water in the United States in 2015 (Dieter and others, 2018a). Differences result from (1) information updates obtained between publication dates, (2) the use of different data sources (such as the USGS use of the U.S. Census data for the national report and the WMDs use of the Bureau of Economics and Business Research population data), or (3) differences in water-use categories presented in this report and those published at the national level.
Terminology differences-A change in water-source classification within the USGS WAUSP (formerly the USGS National Water Use Program) occurred between 2005 and 2010 when nonpotable groundwater was reclassified from freshwater to saline water. For 2010, nonpotable groundwater was classified as saline within the WAUSP and report (Maupin and others, 2014), whereas for Florida it was identified as brackish water but remained classified as freshwater in the 2010 State report (Marella, 2014). In the current report, however, nonpotable groundwater is identified and accounted for as saline water in 2015. Nonpotable groundwater withdrawn for public supply in Florida is treated through a desalination process or diluted with freshwater to meet drinking-water standards set by the FDEP (Florida Department of Environmental Regulation, 1990). In 2015, a small amount of surface water was withdrawn for public supply from a saline source and is reported herein as treated saline water.

\section{Water Withdrawals and Use}

In 2015, the total water withdrawn in Florida was estimated to be 15,319 million gallons per day (Mgal/d) (table 1). Saline water accounted for $9,598 \mathrm{Mgal} / \mathrm{d}$ (63 percent) and freshwater accounted for $5,721 \mathrm{Mgal} / \mathrm{d}$ (37 percent) of total water withdrawals in 2015 (fig. 3). Groundwater accounted for 3,604 Mgal/d (63 percent) of freshwater withdrawals, and surface water accounted for the remaining 2,117 Mgal/d (37 percent). Surface water accounted for 9,401 Mgal/d (98 percent) of the saline-water withdrawals, and groundwater accounted for the remaining $198 \mathrm{Mgal} / \mathrm{d}$ (2 percent) (table 1). In addition to the total water withdrawn statewide, $738 \mathrm{Mgal} / \mathrm{d}$ of reclaimed wastewater was also used throughout Florida during 2015. More than three-quarters (83 percent) of the reclaimed wastewater-discharge flow in 2015 was used to reduce potable-quality water withdrawals for urban irrigation (public-access areas, including golf courses and residential lawns), agricultural irrigation, and

Table 1. Total water withdrawals by in Florida by category, 2015.

[Data compiled during this study are available as a U.S. Geological Survey data release (Marella and Dixon, 2018). All values in million gallons per day]

\begin{tabular}{l|rrr|rrr|r}
\hline \multirow{2}{*}{\multicolumn{1}{c|}{ Category }} & \multicolumn{3}{c|}{ Freshwater } & \multicolumn{3}{c|}{ Saline water } & All water \\
\cline { 2 - 7 } & Ground & Surface & Total & Ground & Surface & Total & Total \\
\hline Public supply & $1,908.67$ & 305.91 & $2,214.58$ & $169.14^{\mathrm{a}}$ & $1.13^{\mathrm{a}}$ & $170.27^{\mathrm{a}}$ & $2,384.85$ \\
Domestic self-supplied & 176.92 & 0.00 & 176.92 & 0.00 & 0.00 & 0.00 & 176.92 \\
$\begin{array}{l}\text { Commercial-industrial-mining } \\
\quad \text { self-supplied }\end{array}$ & 297.90 & 111.09 & 408.99 & 0.00 & 3.10 & 3.10 & 412.09 \\
Agricultural self-supplied & & & & & & \\
Recreational-landscape irrigation & $1,010.67$ & $1,078.13$ & $2,088.80$ & 0.00 & 0.00 & 0.00 & $2,088.80$ \\
Power generation & 27.93 & 215.58 & 397.51 & 0.00 & 0.00 & 0.00 & 397.51 \\
\hline Totals & $3,603.92$ & $2,116.90$ & $5,720.82$ & 197.66 & $9,400.54$ & $9,598.20$ & $15,319.02$ \\
\hline
\end{tabular}

${ }^{a}$ Includes water withdrawn that is either treated through a desalination process or diluted with freshwater to meet drinking water standards (Florida Department of Environmental Regulation, 1990). Prior to 2015, this water was classified as freshwater, but for this publication it is designated as saline. 


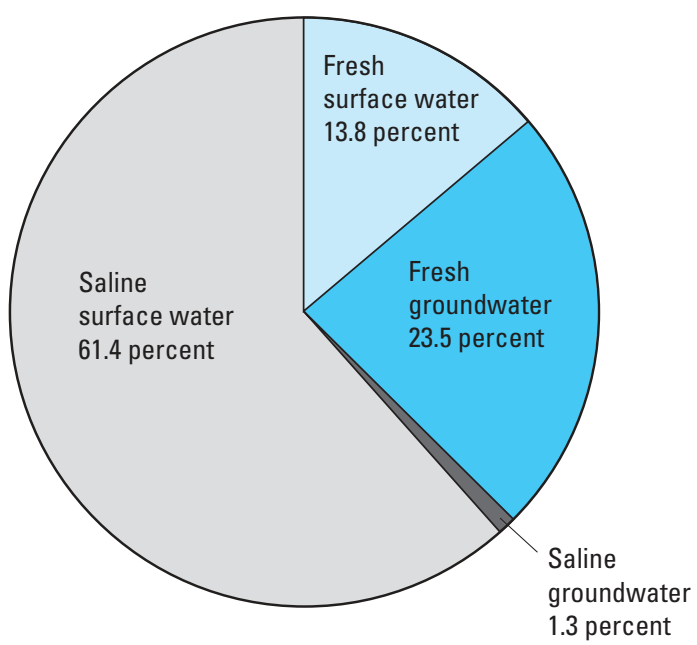

Figure 3. Total water withdrawals in Florida by source, 2015.

industrial use, and the remaining 17 percent of the reclaimed wastewater was returned to the hydrologic system as aquifer recharge (13 percent) and wetland augmentation (4 percent)

(Florida Department of Environmental Protection, 2016).

The freshwater withdrawn in 2015 is equivalent in volume to an estimated 3.5-inch (in.) thick layer of water covering the entire 54,252 square miles of Florida's land area (Fernald and Purdum, 1992) or about 7 percent of the rainfall for 2015, which averaged 53 in. statewide (Florida State University, 2017). The relative importance of freshwater withdrawals within a local or regional water budget can vary temporally and spatially.

Overall, public supply was the largest use of freshwater in 2015, accounting for 39 percent of total freshwater withdrawals, followed by agricultural self-supplied at 37 percent (table 1). For fresh groundwater withdrawals, public supply (53 percent) and agricultural (28 percent) were the largest uses in 2015 , followed by commercial-industrial-mining self-supplied ( 8 percent), domestic self-supplied and recreational-landscape irrigation (5 percent each), and power generation (less than 1 percent) (fig. 4 and table 1). For fresh surface-water withdrawals, agricultural (51 percent) was the largest use in 2015, followed by power generation (19 percent), public supply (15 percent), recreational-landscape irrigation (10 percent), and commercial-industrial-mining self-supplied (5 percent) (fig. 4 and table 1). Public supply accounted for 86 percent of the saline groundwater withdrawn, followed by power generation (14 percent). Power generation accounted for nearly all (greater than 99.9 percent) of the saline surface-water withdrawals in 2015.

Freshwater withdrawals were greatest in Palm Beach County $(820 \mathrm{Mgal} / \mathrm{d})$ in southeast Florida, and saline-water withdrawals were greatest in Pasco County $(1,776 \mathrm{Mgal} / \mathrm{d})$ (table 2) in west-central Florida (fig. 2). Fresh groundwater withdrawals exceeded $200 \mathrm{Mgal} / \mathrm{d}$ in Miami-Dade, Orange, Broward, Palm Beach, and Polk Counties. Fresh surface-water withdrawals exceeded $200 \mathrm{Mgal} / \mathrm{d}$ in Palm Beach and Hendry Counties.

\section{Water Source and Use by Category}

Florida consistently has been one of the largest users of groundwater in the Nation over the past few decades (Hutson and others, 2004; Kenny and others, 2009; Maupin and others, 2014; Dieter and others, 2018a). Fresh groundwater is available throughout the State and generally needs little or no treatment prior to use (Vecchioli and Foose, 1985). Overall, groundwater sources provided drinking water to more than 92 percent of Florida's population (18.324 million people) from public-water supply systems (16.252 million people) and private domestic household wells (2.073 million people) in 2015.

Groundwater withdrawals in Florida for 2015 totaled 3,802 Mgal/d, of which 3,604 Mgal/d was freshwater and $198 \mathrm{Mgal} / \mathrm{d}$ was saline water (table 1). Of the saline groundwater withdrawn, $169 \mathrm{Mgal} / \mathrm{d}$ (85 percent) was nonpotable and was either blended or treated to meet potable (drinking-water) standards. The nonpotable groundwater is herein considered saline water. About 2,360 Mgal/d (62 percent) of the groundwater withdrawn in 2015 was from the Floridan aquifer system (fig. 5 and table 3), which includes nearly all of the $169 \mathrm{Mgal} / \mathrm{d}$ of saline groundwater withdrawn. Orange and Polk Counties were the largest users of water from the Floridan aquifer system (table 3 ). This aquifer system, which underlies all of Florida and parts of Alabama, Georgia, and South Carolina, is not the only source of groundwater used in the State. In many areas of Florida, other local aquifers can provide good quality groundwater (fig. 5), especially in areas where the Floridan aquifer system is nonpotable. In 2015, the Biscayne aquifer supplied $682 \mathrm{Mgal} / \mathrm{d}$ (18 percent) of the groundwater withdrawn, and the remaining 20 percent was supplied by the surficial aquifer system (450 Mgal/d), the intermediate aquifer system $(225 \mathrm{Mgal} / \mathrm{d})$, and the sand and gravel aquifer system ( $85 \mathrm{Mgal} / \mathrm{d}$ ) (fig. 5 and table 3). The sand and gravel aquifer system is part of the Coastal Lowlands aquifer system, which underlies Alabama, western Florida, Louisiana, Mississippi, and Texas (Miller, 1990; Renken, 1998). The surficial aquifer system is primarily tapped by private domestic household wells or by public-supply wells in areas where the Floridan aquifer system is nonpotable or is too deep to be tapped economically.

Saline surface water is abundant within the numerous coastal rivers and bays of Florida along its nearly 1,200-mile coastline (Fernald and Purdum, 1992), whereas fresh surface water is available throughout most of the State from rivers, lakes, or managed and maintained canal systems; however, a large percentage of all fresh surface water in Florida is considered nonpotable, and it usually needs treatment of some sort for uses other than irrigation or cooling. Fresh surface water only provided drinking water to 8 percent of Florida's population (1.491 million people) from public-water supply systems in 2015. In many cases, these public suppliers that use surface water often augment their supply with groundwater.

Surface-water withdrawals in Florida totaled $11,517 \mathrm{Mgal} / \mathrm{d}$ in 2015. Saline surface water accounted for $9,401 \mathrm{Mgal} / \mathrm{d}$ (82 percent) and freshwater accounted 


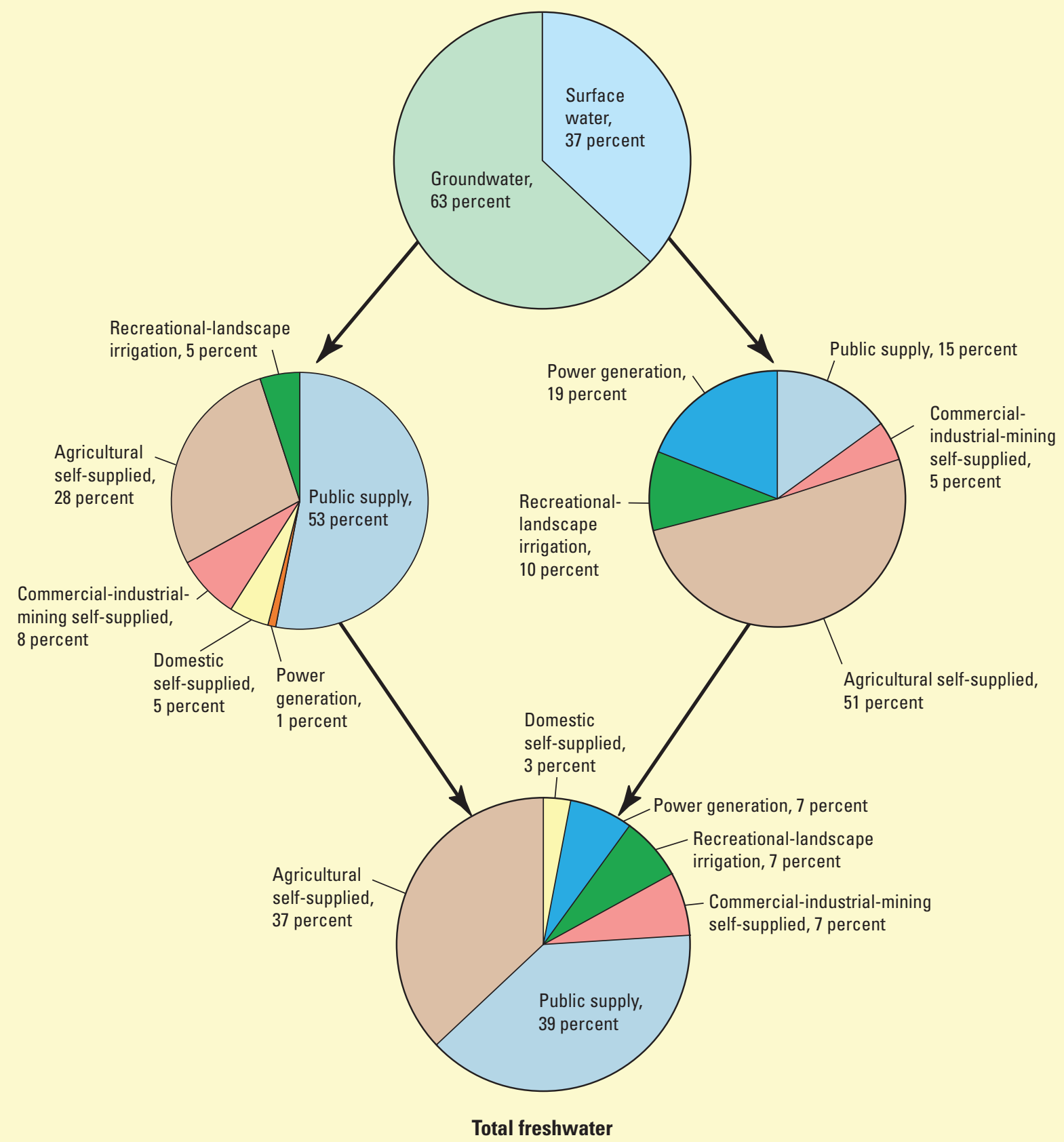

Figure 4. Freshwater withdrawals in Florida by category and water source, 2015.

for 2,117 Mgal/d (18 percent) of the total surface-water withdrawals. Nearly all saline withdrawals (99.9 percent) were used for once-through cooling water, with nearly all of this water being returned to the source upon use. Fresh surface water in Florida is primarily used for irrigation and power generation, which together composed more than two-thirds (70 percent) of the fresh surface water withdrawn in 2015 (fig. 4 and table 1). Much of the fresh surface-water withdrawals (52 percent) occurred in Palm Beach, Hendry, Martin, and Glades Counties (table 2). These counties are associated with the canals in the Everglades Agricultural Area as well as the Caloosahatchee River and its tributaries associated with Lake Okeechobee (fig. 6). Surface water from these sources is most often diverted through canals or ditches and then pumped or gravity-fed onto fields or citrus groves by means of various flood irrigation systems. Throughout Florida, a large percentage of the surface water used for flood or seepage irrigation in fields or groves is not consumed, because excess water is most often pumped back into the canals or ditches for further use. In addition, many of the canals, ditches, or ponds that are used for flood irrigation throughout Florida often are augmented with groundwater from pumped or free-flowing wells to help maintain water levels in the canals. 
Table 2. Total water withdrawals by in Florida by county, 2015.

[Data compiled during this study are available as a U.S. Geological Survey data release (Marella and Dixon, 2018). All values in million gallons per day]

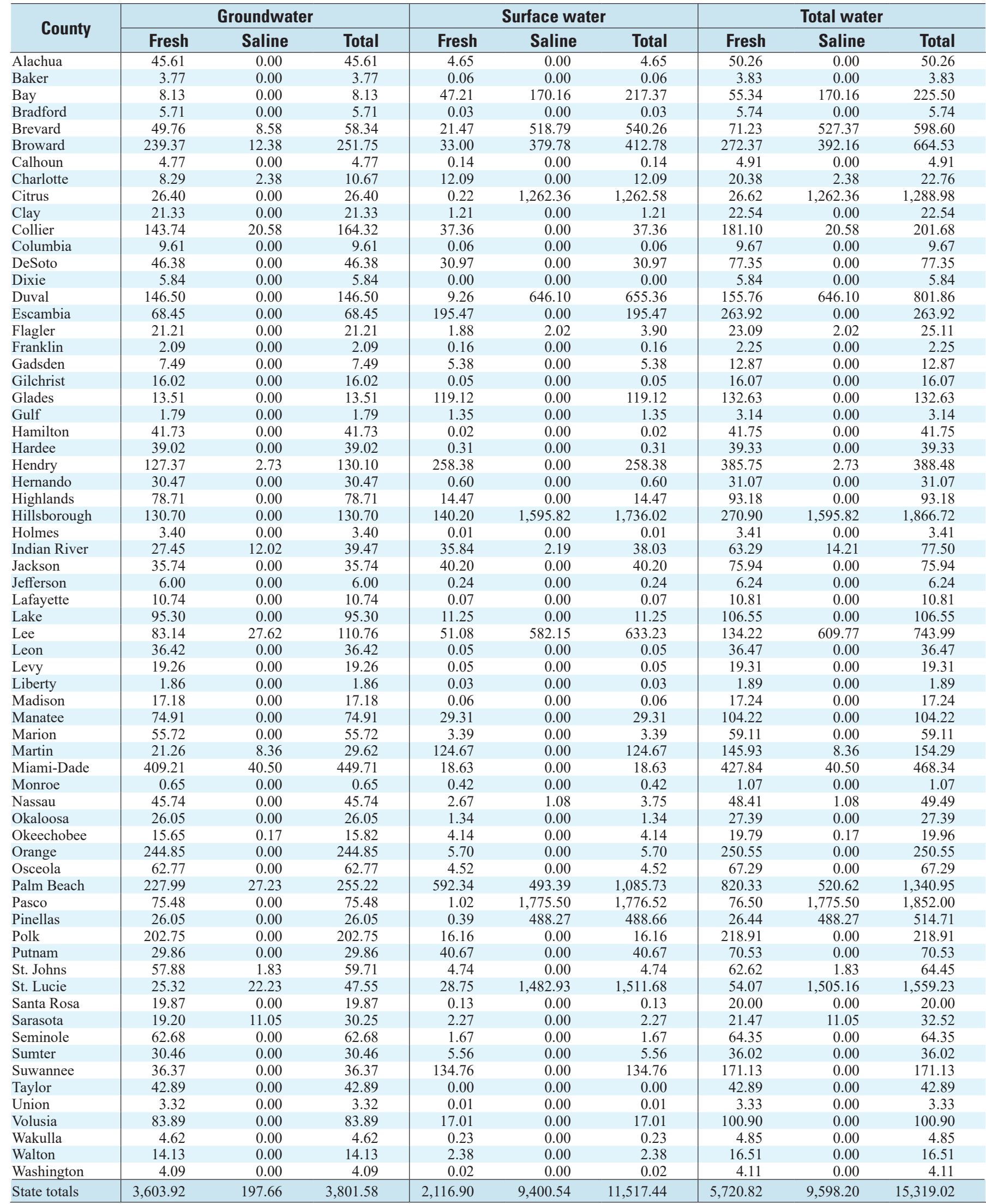




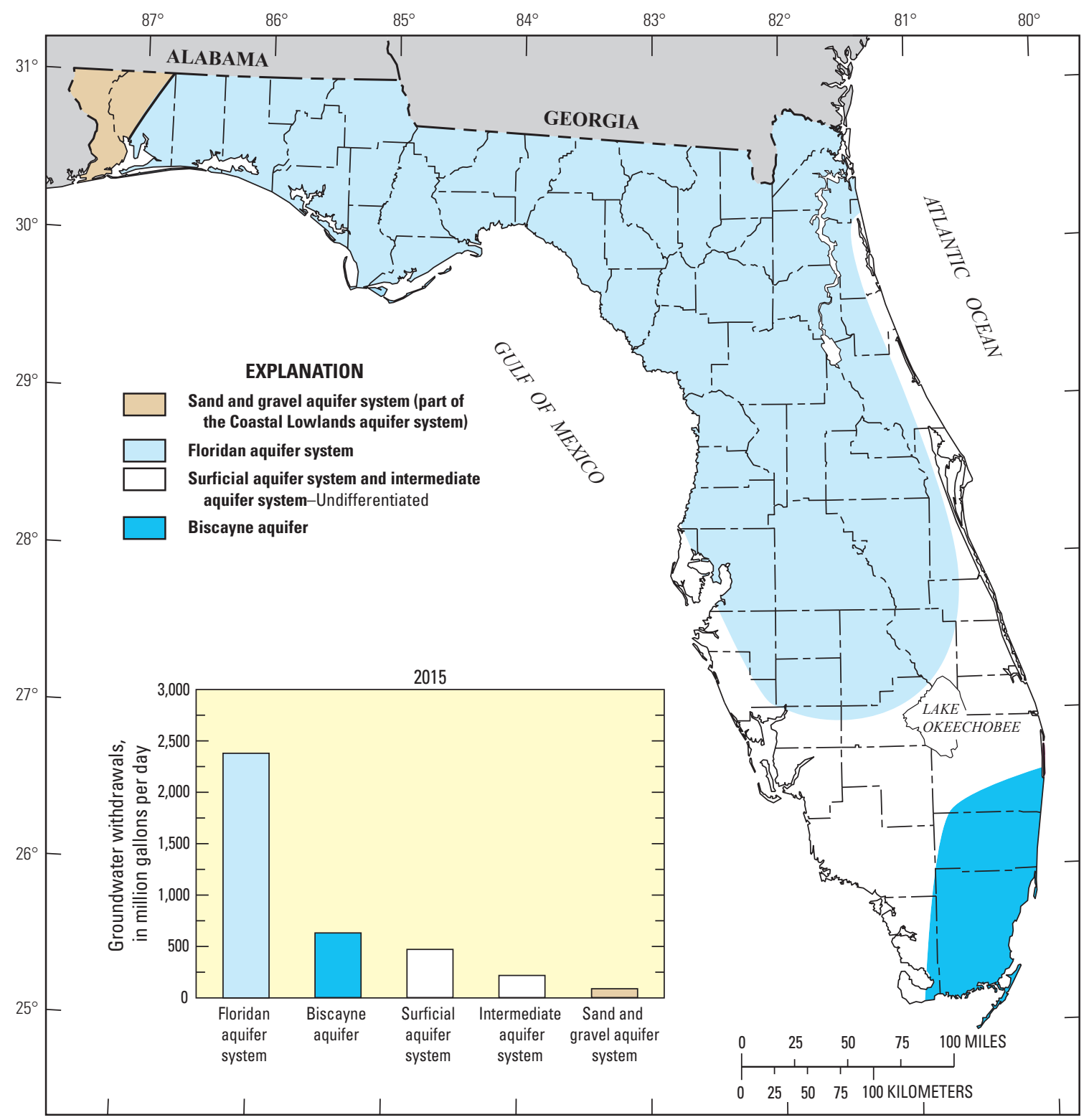

Base modified from U.S. Geological Survey Florida State base map, 1:500,000, 1974

Figure 5. Approximate areal extent throughout which principal aquifers in Florida are the primary source of groundwater, and quantity of groundwater withdrawals, 2015. From Vecchioli and Foose (1985), Miller (1990), and Renken (1998).

\section{Public Supply}

The public-supply category refers to water distributed by a publicly or privately owned water system. Florida had 1,646 community, 788 nontransient noncommunity, and 2,841 transient noncommunity active water systems in 2015 (Kenna Study, Florida Department of Environmental Protection, written commun., July 17, 2018). For this report, water-use data were compiled for community water systems that either served at least 400 people or withdrew at least $10,000 \mathrm{gal} / \mathrm{d}(0.01 \mathrm{Mgal} / \mathrm{d})$ and are referred to as inventoried systems. Water withdrawals from the inventoried systems totaled 2,385 Mgal/d and supplied water to nearly 90 percent
(17.743 million) of the State's 19.815 million residents in 2015 (table 4). The inventoried systems represent more than 99.7 percent of total public-supply withdrawals in 2015; the estimated maximum withdrawals by the uninventoried systems would be about $7 \mathrm{Mgal} / \mathrm{d}$ (793 community systems served less than 400 people, then multiplied by $0.009 \mathrm{Mgal} / \mathrm{d}$ ), and this water use would be accounted for under the domestic self-supplied category. The public-supply category does not include public water systems that serve nonpermanent populations, such as those at correctional institutions, schools, and military facilities, and nontransient noncommunity and transient noncommunity water systems such as churches, restaurants, theme parks, and others that provide drinking 
Table 3. Total groundwater withdrawals by principal aquifer in Florida by county, 2015.

[Source: U.S. Geological Survey, Caribbean-Florida Water Science Center - Orlando. All values in million gallons per day]

\begin{tabular}{|c|c|c|c|c|c|c|}
\hline County & $\begin{array}{c}\text { Floridan } \\
\text { aquifer system }\end{array}$ & $\begin{array}{c}\text { Biscayne } \\
\text { aquifer }\end{array}$ & $\begin{array}{c}\text { Surficial } \\
\text { aquifer system }\end{array}$ & $\begin{array}{l}\text { Intermediate } \\
\text { aquifer system }\end{array}$ & $\begin{array}{c}\text { Sand-gravel } \\
\text { aquifer system }\end{array}$ & Total \\
\hline Alachua & 45.61 & 0.00 & 0.00 & 0.00 & 0.00 & 45.61 \\
\hline Baker & 3.77 & 0.00 & 0.00 & 0.00 & 0.00 & 3.77 \\
\hline Bradford & 5.71 & 0.00 & 0.00 & 0.00 & 0.00 & 5.71 \\
\hline Brevard & 47.35 & 0.00 & 10.99 & 0.00 & 0.00 & 58.34 \\
\hline Broward & 12.38 & 239.37 & 0.00 & 0.00 & 0.00 & 251.75 \\
\hline Calhoun & 4.77 & 0.00 & 0.00 & 0.00 & 0.00 & 4.77 \\
\hline Clay & 21.33 & 0.00 & 0.00 & 0.00 & 0.00 & 21.33 \\
\hline Collier & 20.58 & 0.00 & 70.49 & 73.25 & 0.00 & 164.32 \\
\hline Columbia & 9.61 & 0.00 & 0.00 & 0.00 & 0.00 & 9.61 \\
\hline DeSoto & 40.59 & 0.00 & 0.00 & 5.79 & 0.00 & 46.38 \\
\hline Dixie & 5.84 & 0.00 & 0.00 & 0.00 & 0.00 & 5.84 \\
\hline Duval & 136.31 & 0.00 & 9.55 & 0.64 & 0.00 & 146.50 \\
\hline Escambia & 0.00 & 0.00 & 0.00 & 0.00 & 68.45 & 68.45 \\
\hline Gulf & 1.67 & 0.00 & 0.00 & 0.12 & 0.00 & 1.79 \\
\hline Hamilton & 41.73 & 0.00 & 0.00 & 0.00 & 0.00 & 41.73 \\
\hline Hardee & 35.28 & 0.00 & 0.00 & 3.74 & 0.00 & 39.02 \\
\hline Hendry & 15.03 & 0.00 & 51.28 & 63.79 & 0.00 & 130.10 \\
\hline Hernando & 30.47 & 0.00 & 0.00 & 0.00 & 0.00 & 30.47 \\
\hline Highlands & 70.64 & 0.00 & 0.00 & 8.07 & 0.00 & 78.71 \\
\hline Hillsborough & 124.32 & 0.00 & 0.36 & 6.02 & 0.00 & 130.70 \\
\hline Holmes & 3.40 & 0.00 & 0.00 & 0.00 & 0.00 & 3.40 \\
\hline Indian River & 32.17 & 0.00 & 7.30 & 0.00 & 0.00 & 39.47 \\
\hline Jackson & 35.74 & 0.00 & 0.00 & 0.00 & 0.00 & 35.74 \\
\hline Jefferson & 6.00 & 0.00 & 0.00 & 0.00 & 0.00 & 6.00 \\
\hline Lafayette & 10.74 & 0.00 & 0.00 & 0.00 & 0.00 & 10.74 \\
\hline Lake & 95.30 & 0.00 & 0.00 & 0.00 & 0.00 & 95.30 \\
\hline Lee & 27.62 & 0.00 & 47.45 & 35.69 & 0.00 & 110.76 \\
\hline Nassau & 42.65 & 0.00 & 2.90 & 0.19 & 0.00 & 45.74 \\
\hline Okaloosa & 25.92 & 0.00 & 0.00 & 0.00 & 0.13 & 26.05 \\
\hline Okeechobee & 12.37 & 0.00 & 3.45 & 0.00 & 0.00 & 15.82 \\
\hline Orange & 244.85 & 0.00 & 0.00 & 0.00 & 0.00 & 244.85 \\
\hline Osceola & 62.77 & 0.00 & 0.00 & 0.00 & 0.00 & 62.77 \\
\hline Palm Beach & 27.23 & 33.32 & 194.67 & 0.00 & 0.00 & 255.22 \\
\hline Pasco & 75.48 & 0.00 & 0.00 & 0.00 & 0.00 & 75.48 \\
\hline Pinellas & 26.05 & 0.00 & 0.00 & 0.00 & 0.00 & 26.05 \\
\hline Polk & 193.45 & 0.00 & 0.00 & 9.30 & 0.00 & 202.75 \\
\hline Putnam & 29.61 & 0.00 & 0.25 & 0.00 & 0.00 & 29.86 \\
\hline St. Johns & 53.86 & 0.00 & 5.85 & 0.00 & 0.00 & 59.71 \\
\hline St. Lucie & 35.03 & 0.00 & 12.52 & 0.00 & 0.00 & 47.55 \\
\hline Santa Rosa & 3.96 & 0.00 & 0.00 & 0.00 & 15.91 & 19.87 \\
\hline Sarasota & 19.80 & 0.00 & 8.56 & 1.89 & 0.00 & 30.25 \\
\hline Seminole & 62.68 & 0.00 & 0.00 & 0.00 & 0.00 & 62.68 \\
\hline Sumter & 30.46 & 0.00 & 0.00 & 0.00 & 0.00 & 30.46 \\
\hline Suwannee & 36.37 & 0.00 & 0.00 & 0.00 & 0.00 & 36.37 \\
\hline Taylor & 42.89 & 0.00 & 0.00 & 0.00 & 0.00 & 42.89 \\
\hline Union & 3.32 & 0.00 & 0.00 & 0.00 & 0.00 & 3.32 \\
\hline Volusia & 83.89 & 0.00 & 0.00 & 0.00 & 0.00 & 83.89 \\
\hline Wakulla & 4.62 & 0.00 & 0.00 & 0.00 & 0.00 & 4.62 \\
\hline Walton & 14.08 & 0.00 & 0.00 & 0.00 & 0.05 & 14.13 \\
\hline Washington & 4.09 & 0.00 & 0.00 & 0.00 & 0.00 & 4.09 \\
\hline State totals & $2,359.97$ & 681.90 & 449.93 & 225.24 & 84.54 & $3,801.58$ \\
\hline
\end{tabular}




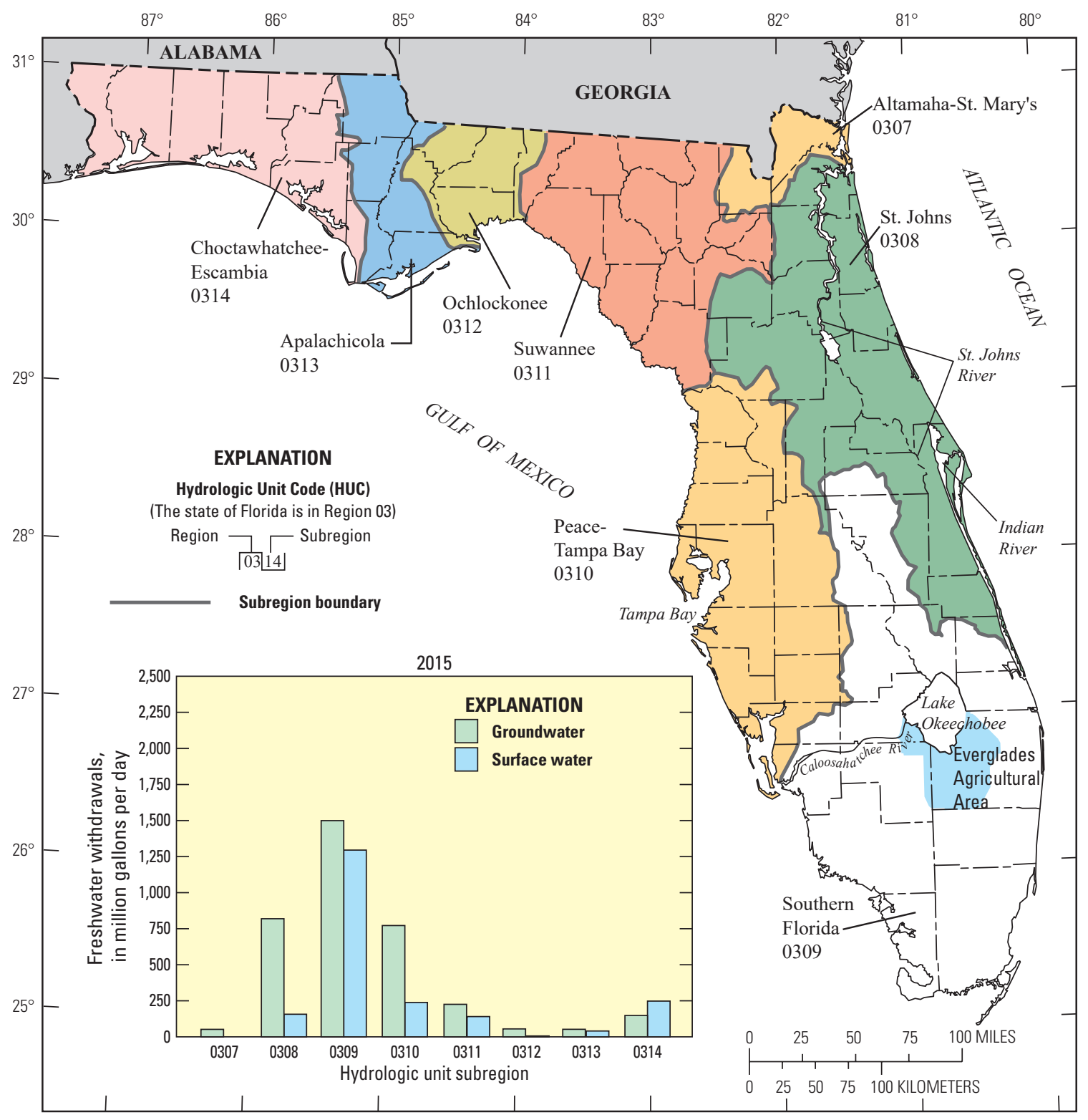

Base modified from U.S. Geological Survey

Florida State base map, 1:500,000, 1974

Figure 6. General location of hydrologic units in Florida and fresh groundwater and surface-water withdrawals within these units, 2015. From U.S. Geological Survey (1975) and Seaber and others (1984).

water to a nonpermanent or transient population. These users are included in the commercial-industrial-mining self-supplied category for this report if they are large enough to require a consumptive water-use permit or submit withdrawal volumes to the local WMD or FDEP.

Groundwater supplied 2,078 Mgal/d (87 percent) of the public-supply water withdrawn in 2015 and provided drinking water to 16.252 million people. Of the groundwater withdrawn, 1,909 Mgal/d was freshwater and $169 \mathrm{Mgal} / \mathrm{d}$ was saline water. The Floridan aquifer system supplied nearly 57 percent $(1,175 \mathrm{Mgal} / \mathrm{d})$ of the total public-supply groundwater withdrawals and served an estimated 9.231 million people, whereas the Biscayne aquifer supplied 28 percent (592 Mgal/d) of the total public-supply groundwater withdrawals and served 4.632 million people. The remaining groundwater withdrawn for public supply was obtained from the surficial aquifer system (237 Mgal/d), which served 1.820 million people; the sand and gravel aquifer system (49 Mgal/d), which served 0.374 million people; and the intermediate aquifer system $(25 \mathrm{Mgal} / \mathrm{d})$, which served 0.195 million people.

Surface water supplied $307 \mathrm{Mgal} / \mathrm{d}$ (13 percent) of the public-supply water withdrawn in 2015 and provided drinking water to 1.491 million people. Of the surface water withdrawn, slightly more than $1 \mathrm{Mgal} / \mathrm{d}$ was saline water and was treated through a desalination process for public-supply use. The 
Table 4. Public-supply population, water use, withdrawals, transfers, and treated water in Florida by county, 2015.

[Source: U.S. Geological Survey; Caribbean-Florida Water Science Center - Orlando. Water values in million gallons per day; per capita values in gallons per day]

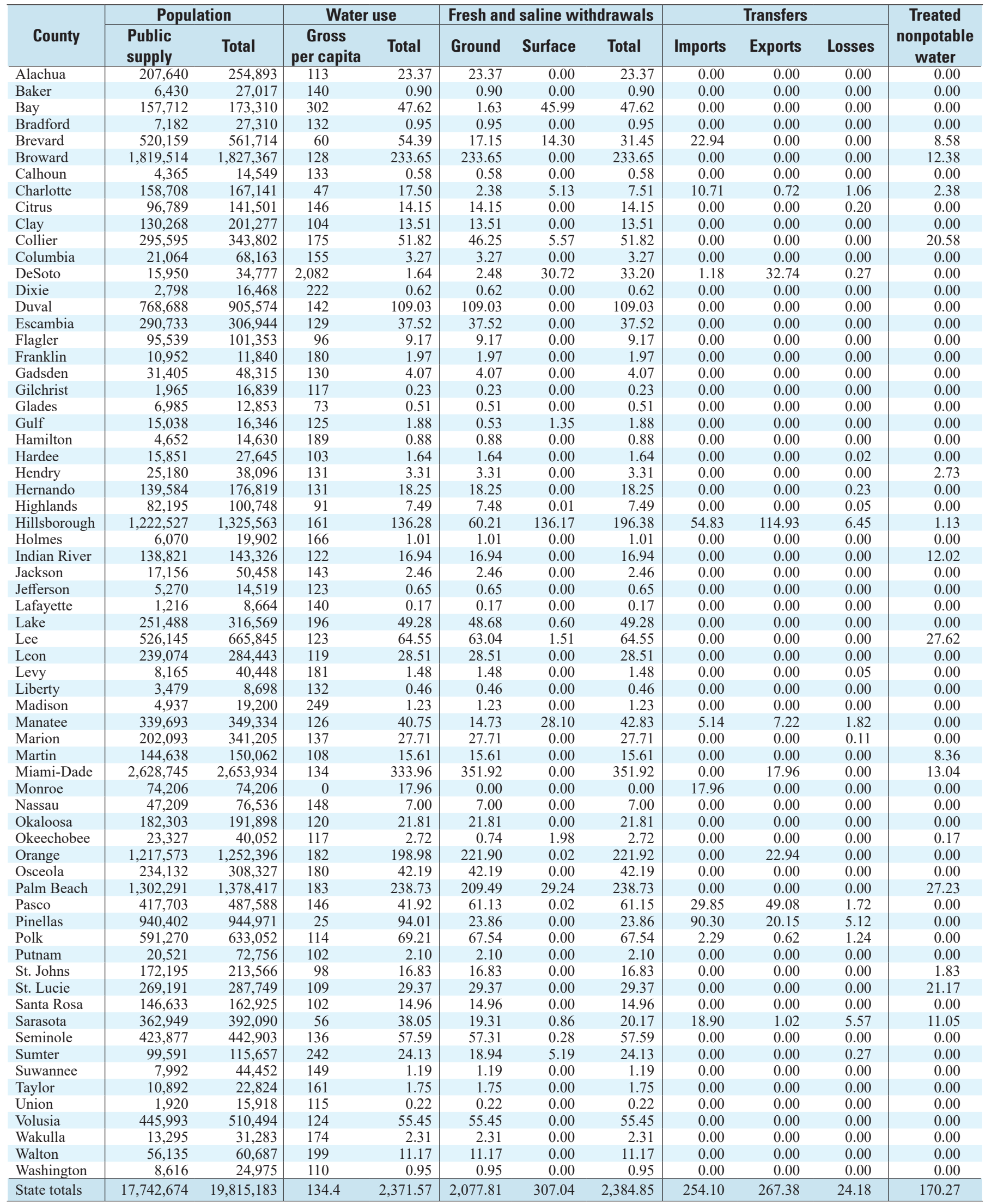


reservoirs along the Hillsborough River, Tampa Bypass Canal, and the Alafia River in Hillsborough County combined supplied 44 percent of the total surface water for public supply (Ferguson, 2016), followed by Deer Point Lake in Bay County (15 percent) and Clear Lake in Palm Beach County (9 percent) (water features shown in fig. 2). Several public-supply water systems in Florida that withdraw surface water also augment their water supply with groundwater, usually during periods of high demand or low surface-water levels. In addition, several water suppliers inject and store the excess surface water that becomes available during the wet season into a deep aquifer and then recover it during the dry season, if needed, to help offset peak demand (Reese, 2006). Values for the amount of water injected into groundwater sources for aquifer storage and recovery systems are not presented in this report.

Public suppliers deliver water for domestic use (household use), commercial use, industrial use, public uses (including processing and distribution losses), and other uses. Domestic water use, which includes indoor and outdoor household uses, accounted for just under 64 percent $(1,503 \mathrm{Mgal} / \mathrm{d})$ of the public-supply withdrawals in 2015 (fig. 7 and table 5). Domestic water use was derived from the residual of the total public-supply net water use in each county (withdrawals plus imports or minus exports) minus the commercial, industrial, public uses, and other uses. Water deliveries to commercial and industrial users from public supply were estimated by multiplying county employment totals (U.S. Census Bureau, 2017) by a water-use coefficient based on average water use per employee (Davis and others, 1988) for various commercial and industrial employment sectors (Bucca and Marella, 1992). Deliveries of public-supply water to commercial and industrial users totaled $600 \mathrm{Mgal} / \mathrm{d}$ in 2015, of which $524 \mathrm{Mgal} / \mathrm{d}$ (22 percent) was for commercial use and $76 \mathrm{Mgal} / \mathrm{d}$ (3 percent) was for industrial use (fig. 7 and table 5). Public uses, losses, and other uses, which include water used for firefighting and system maintenance, as well as all losses, accounted for 11 percent (269 Mgal/d) of the total public-supply withdrawals in 2015 (fig. 7 and

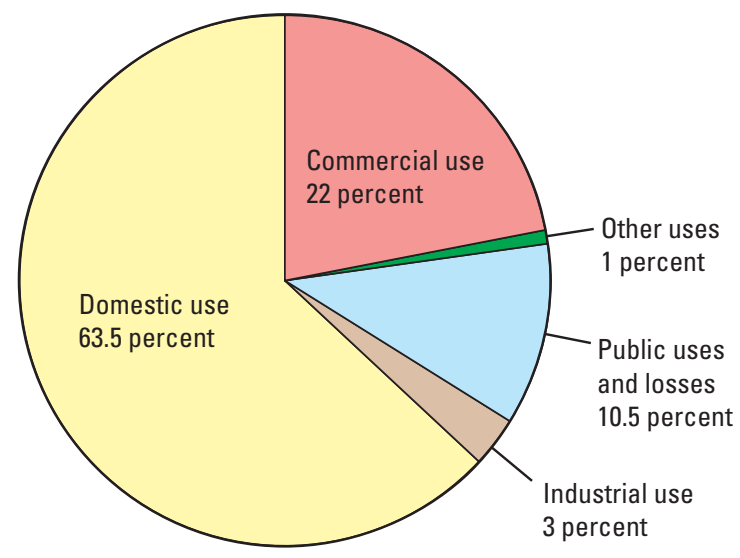

Figure 7. Public-supply water-use deliveries in Florida, 2015. table 5). For 2015, public uses and other uses were estimated at 1 percent (American Water Works Association, 1992), and losses were estimated at 10 percent (Friedman and Heaney, 2009). Losses also include water lost during its transmission from water sources to utility distribution, as well as losses that occur during water processing such as desalination or water softening. An additional 1 percent water loss was applied in counties where desalination or dilution was occurring because of the extra water losses associated with that process (Buros, 1989; Dykes and Conlon, 1989). In addition, an estimated $13 \mathrm{Mgal} / \mathrm{d}$ of water was lost during transmission on several large intercounty water transfers not assigned to any one county (Ferguson, 2016), as shown in the totals for water use and water withdrawals in table 4. Prior to 2010, public-supply water system losses were estimated at 14 percent (Marella, 2014), but permitting constraints by the WMDs since then has required that public-supply water systems lower their distribution losses to between 10 and 12 percent (Friedman and Heaney, 2009). Other uses include deliveries for irrigation (residential, commercial, and recreational), construction, parks, city common areas (including medians), augmentation of air-conditioning cooling reservoirs, power generation, and other deliveries that do not fall within a specific category.

The statewide gross per capita water use for public supply in Florida was 134 gal/d in 2015 (fig. 8 and table 5). This value is calculated as the total public-supply water use $(2,372 \mathrm{Mgal} / \mathrm{d}$, as shown on tables 4 and 5$)$ divided by the

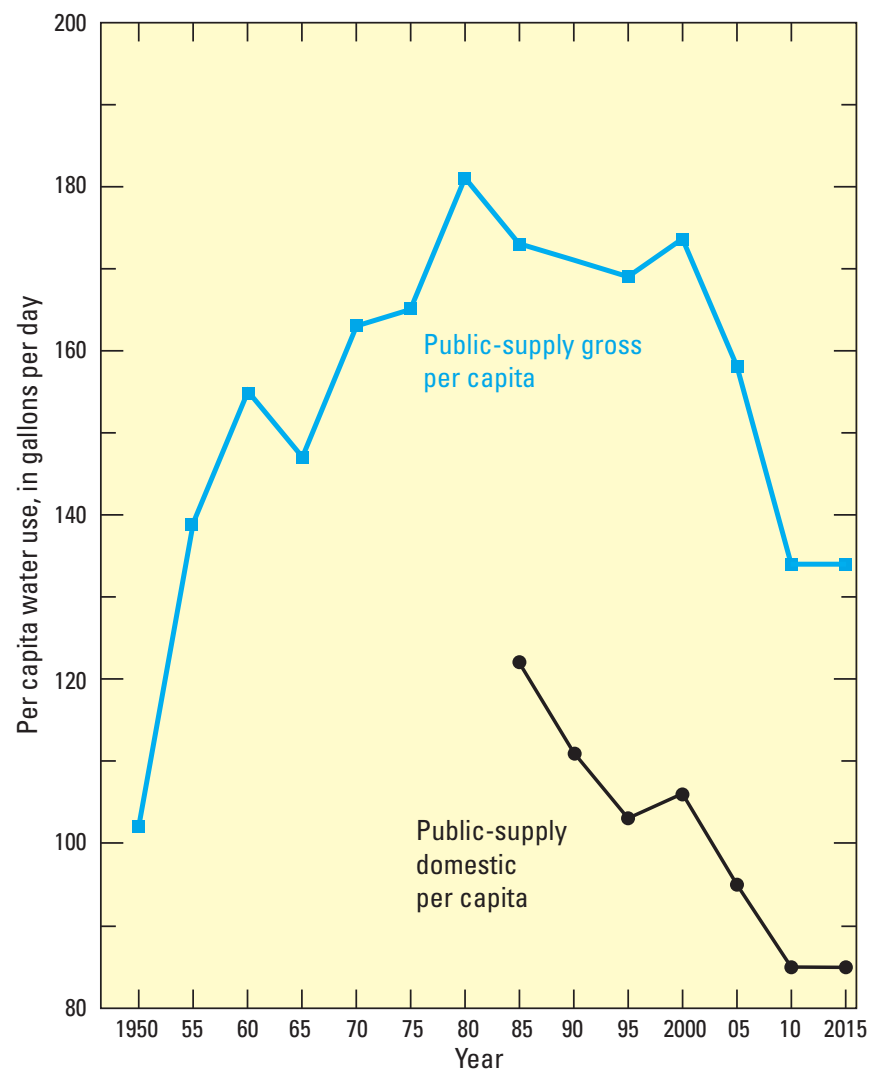

Figure 8. Historical public-supply gross and domestic per capita water use in Florida, 1950-2015. Modified from Marella (2014). 
Table 5. Estimated public-supply water use (deliveries), and per capita use in Florida by county, 2015.

[Source: U.S. Geological Survey; Caribbean-Florida Water Science Center - Orlando]

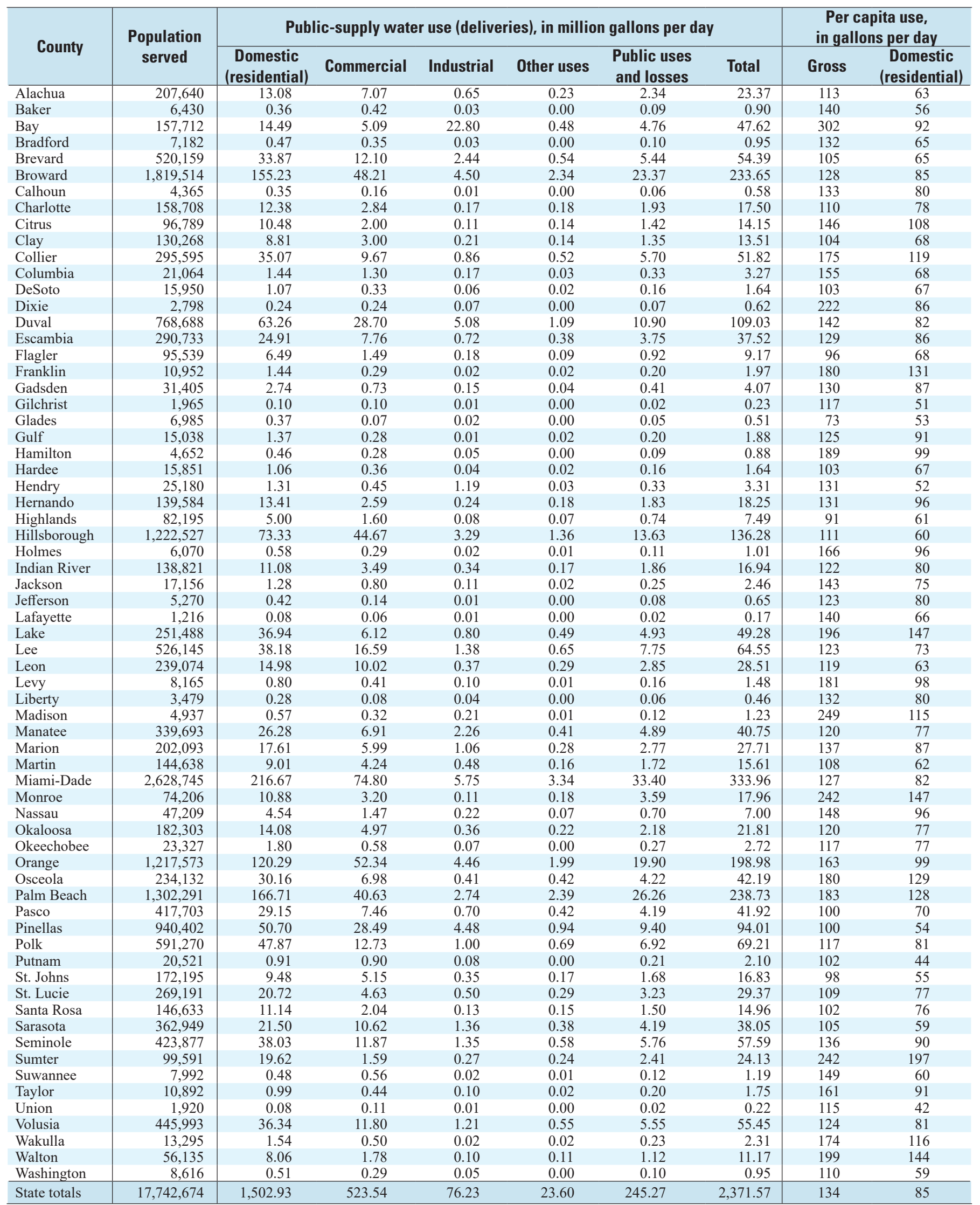


total population served by public supply (17.743 million). Per capita water use calculated in this manner includes water delivered for all uses of public-supply water, as shown in table 5 (domestic, commercial, industrial, public uses and losses, and other uses). Florida's public-supply domestic per capita water use for 2015 was estimated to be $85 \mathrm{gal} / \mathrm{d}$ (fig. 8 and table 5). This per capita use is calculated by dividing the deliveries for domestic use (1,503 Mgal/d) from public suppliers (table 5) by the population served (17.743 million) and excludes all other uses of public-supply water (commercial, industrial, public uses and losses, or other uses). Overall, per capita water use in Florida has been decreasing since 1985, with the exception of 2000 (Marella, 2014); however, there was no change in the public-supply gross or domestic per capita water use between 2010 and 2015 (fig. 8). The long-term decrease is a result of many factors such as increased efficiency of appliances and plumbing fixtures; water conservation through improved education of users, changes in utility rate structures, and better loss-prevention programs; the availability of reclaimed wastewater as a lawn irrigation option; water management mandates and permit constraints on water suppliers; and smaller lot sizes for new single-family homes (Marella, 2014). The singular increase in 2000 was a direct result of extremely low rainfall for that year (Verdi and others, 2006). Another factor that would heavily influence a decrease in public-supply per capita water use in Florida is a shift by residential and commercial public-supply customers from using public supplied water for lawn or landscaping irrigation to obtaining water from a canal, lake, or individual well used exclusively for this irrigation purpose. The water withdrawn by these users would not be accounted for in this report, because the canals, lakes, or wells used for self-supplied lawn or landscape irrigation are not regulated or inventoried as part of this study.

The largest water withdrawals for public supply were in Miami-Dade, Palm Beach, Broward, and Orange Counties, where withdrawals exceeded $200 \mathrm{Mgal} / \mathrm{d}$ in 2015 (table 4). The Florida Keys Aqueduct Authority (http://www.fkaa.com) in 2015 obtained all of its water (18 Mgal/d) for public-supply distribution throughout Monroe County and the Florida Keys from a well field located in southern Miami-Dade County.

Total withdrawals for public supply in Florida increased steadily from 1950, when water-use data were first collected, to 2005 (fig. 9). Total public-supply withdrawals increased by 170 percent between 1970 and 2015 and by 5 percent between 2010 and 2015 (fig. 9). The population of Florida increased by 13 million people (192 percent) between 1970 and 2015, increased by nearly 4 million people ( 24 percent) between 2000 and 2015, and increased by 1 million people ( 5 percent) between 2010 and 2015 (University of Florida, 2015a). As the population of Florida increased between 1970 and 2015, the percentage of the population that relied on public supply increased from 80 percent in 1970 to 90 percent by 2005, but remained at about 90 percent thereafter. Except for the period from 2005 to 2010, data indicate that the long-term (1970-2015) increase in public-supply withdrawals is a result

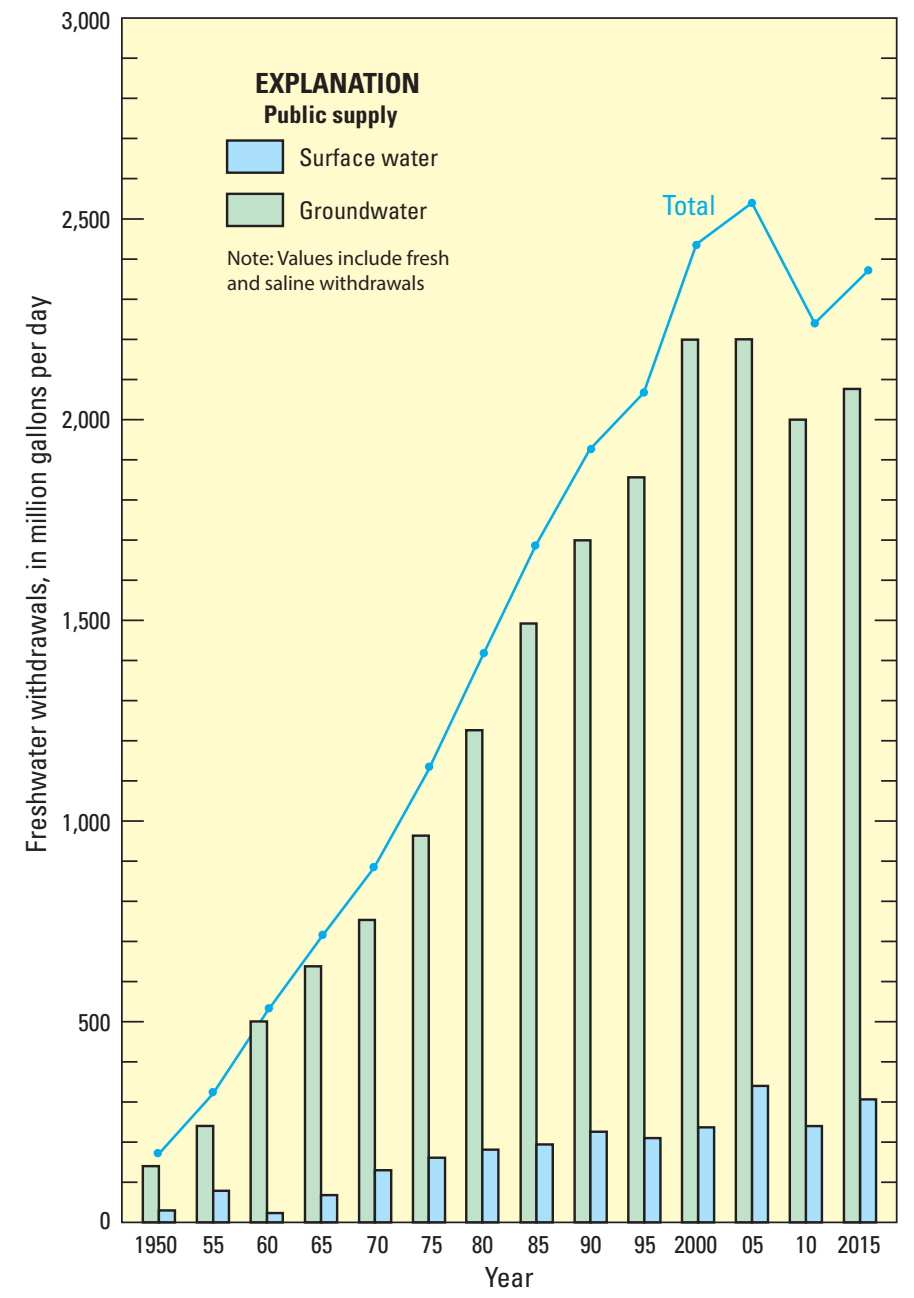

Figure 9. Historical public-supply freshwater withdrawals in Florida by source, 1950-2015. Modified from Marella (2014).

of an increase in the total population and population served and the water demands associated with these increases. However, this increase is slowed somewhat by the use of alternative water sources for lawn watering (reclaimed wastewater or private wells) and water conservation, regulations, and utility mandates, all of which helped offset public-supply water demand over this time.

Use of alternative water sources, such as reclaimed wastewater, has helped lower demands for potable water in several areas of the State, and it is estimated that the statewide reuse per capita for 2015 was $37 \mathrm{gal} / \mathrm{d}$. The use of reclaimed wastewater in 2015 for residential irrigation and public access uses totaled $324 \mathrm{Mgal} / \mathrm{d}$ in 2015, which helped offset potable water withdrawals (Florida Department of Environmental Protection, 2016). In addition, the availability of groundwater and surface water throughout Florida provides many homeowners and commercial properties within public-supply service areas the opportunity to drill a private well or tap a local canal or lake to irrigate lawns and landscaping. These alternative sources also help lower water demands on 
public-supply water systems as less public-supply water is used to irrigate commercial and (or) residential lawns. To date, there is no estimate of the number of lawn-irrigation wells in the State, although it is believed to be substantial. According to a water-well industry report, more than 795,000 wells were drilled in Florida between 2002 and 2011, with the vast majority used for individual purposes (Gale Group, 2013); the report does not differentiate between private domestic household and lawn irrigation wells.

The use of highly mineralized groundwater (often referred to as nonpotable or brackish water) and saline surface water for public supply has increased from $2 \mathrm{Mgal} / \mathrm{d}$ in 1970 (Marella, 2014) to nearly $170 \mathrm{Mgal} / \mathrm{d}$ in 2015. Nearly all $(169 \mathrm{Mgal} / \mathrm{d})$ of this treated water was from saline groundwater, and the remaining $1 \mathrm{Mgal} / \mathrm{d}$ was from saline surface water. The nonpotable water is either treated by using demineralization or desalination techniques (mostly desalination) or is diluted with freshwater to meet FDEP drinking-water standards (Florida Department of Environmental Regulation, 1990) for potable water. The use of desalination or dilution of nonpotable water for public supply in 2015 occurred in 15 counties, mostly along the east and west coasts of Florida (Brevard, Broward, Charlotte, Collier, Hendry, Hillsborough, Indian River, Lee, Martin, Miami-Dade, Okeechobee, Palm Beach, St. Johns, St. Lucie, and Sarasota) (fig. 2 and table 4). Values reported as nonpotable in this report are the amount of water withdrawn for the removal of salt through a desalination process (reverse osmosis, electrodialysis, or another membrane-treatment method) or dilution. Nonpotable groundwater withdrawals presented in this report are accounted for as saline, as classified by the USGS WAUSP. However, these groundwater withdrawals for public supply are considered brackish water but remain classified as freshwater by all of the WMDs (see definitions for brackish water and freshwater in the Glossary). Additionally, water withdrawals for public supply are often treated to reduce hardness or remove particulates and other compounds by using various methods, such as lime-softening, nanofiltration, or other processes. These amounts are neither differentiated in the totals for public supply nor included in the nonpotable treated totals.

\section{Domestic Self-Supplied}

The domestic self-supplied category is composed of users that withdraw small quantities of potable water for drinking-water purposes. Domestic self-supplied use includes water withdrawals from private domestic household wells, community supply wells that serve one or more households, or by the small community water systems not inventoried under public supply, specifically, those having a daily average pumpage of less than $0.01 \mathrm{Mgal} / \mathrm{d}$ or serving fewer than 400 people. Few of these users need a consumptive water-use permit from the WMDs, as their water usage does not exceed a permit threshold; therefore, it is unknown how many wells fall into these three categories in Florida.
For this report, it was assumed that all people not served by the inventoried public suppliers are self-supplied. Of the $177 \mathrm{Mgal} / \mathrm{d}$ withdrawn for domestic self-supplied use in 2015 (table 6), an estimated 96 percent (170 Mgal/d) was from private domestic household wells and 4 percent (7 Mgal/d) was from the estimated 793 small public-supply systems that were not inventoried and accounted for under the public-supply category. Withdrawals of more than $10 \mathrm{Mgal} / \mathrm{d}$ for domestic self-supplied use in 2015 occurred in Duval, Lee, and Marion Counties (table 6). It is assumed that water withdrawals for this category were derived exclusively from groundwater because of its good quality and widespread availability throughout the State. About 70 percent of the domestic self-supplied water withdrawn was obtained from the Floridan aquifer system; the remaining 30 percent was obtained from shallower aquifers across the State, namely the surficial aquifer system (31 Mgal/d), intermediate aquifer system (18 Mgal/d), Biscayne aquifer (3 Mgal/d), and the sand and gravel aquifer system ( $2 \mathrm{Mgal} / \mathrm{d})$. In many areas of Florida, these shallow aquifers yield sufficient water for domestic purposes, especially in areas where the Floridan aquifer system is relatively deep or has poor water quality (fig. 5). In 2015, an estimated 2.073 million people in Florida were self-supplied (table 6). An estimated 1.367 million people (66 percent) obtained their self-supplied well water from the Floridan aquifer system, and the remaining 0.705 million (34 percent) obtained their water from the shallower aquifers.

The number of private domestic household wells in Florida that are used for drinking-water purposes is difficult to estimate, even though the local county health departments and WMDs manage programs to document the construction, completion, and abandonment of such wells. According to the U.S. Census Bureau (1993), 796,000 households in Florida used an individual well as their primary source of drinking water in 1990; however, the census did not compile these data for 2000 or 2010. Assuming that the majority of new households in Florida are connected to public supply, and that a small percentage of homes that used a private domestic household well in the past may have since connected to a public-supply water system as public suppliers expanded their service areas, a modest statewide growth rate of 0.5 percent annually between 1990 and 2015 would increase the number of households that have a private domestic household well to about 897,200 in 2015 . The estimated water use per well would be nearly $190 \mathrm{gal} / \mathrm{d}$ in 2015 (170 Mgal/d divided by 897,200 wells). If this estimate is divided by the statewide average household size of 2.49 individuals in 2015 (University of Florida, 2015b), the water use per well would be $76 \mathrm{gal} / \mathrm{d}$ per person, which is about 12 percent lower than the statewide public-supply domestic per capita use of $85 \mathrm{gal} / \mathrm{d}$. Additionally, many households on public supply in Florida use a private lawn irrigation well exclusively for this use, and these withdrawals are neither included in this category nor in this report.

Withdrawals for domestic self-supplied use in Florida ranged from a peak estimate in 1990 of nearly $300 \mathrm{Mgal} / \mathrm{d}$ 
Table 6. Domestic self-supplied population and water withdrawals in Florida by county, 2015.

[Source: U.S. Geological Survey, Caribbean-Florida Water Science Center - Orlando. Water values in million gallons per day]

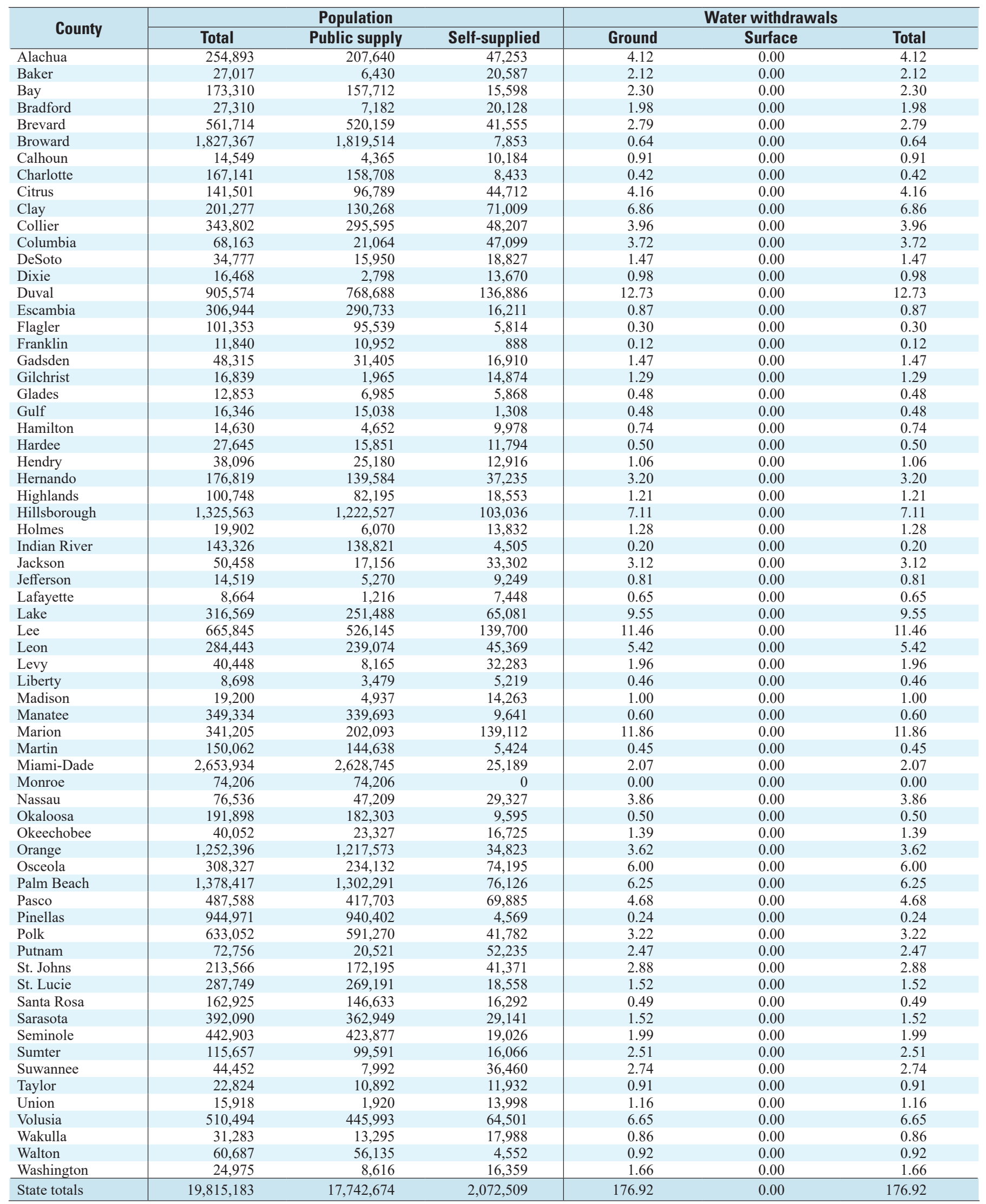


(Marella, 1992) to the current low of $177 \mathrm{Mgal} / \mathrm{d}$ in 2015 (fig. 10). During this same time period (1990-2015), the number of people that relied on domestic household wells averaged 1.9 million. Between 1980 and 2015, two different methods were used to calculate domestic self-supplied withdrawals (Marella, 2014). In 1980, 1985, 1990, and 1995, the self-supplied population in each county was multiplied by the public-supply gross per capita water use, which ranged from 120 to $250 \mathrm{gal} / \mathrm{d}$, for each county to estimate water withdrawals. For 2000, 2005, 2010, and 2015, the statewide public-supply domestic per capita water use was multiplied by the self-supplied population for all counties except those within the SJRWMD and SWFWMD; these two WMDs used either the public-supply gross or an adjusted per capita value in 2015 (as well as in 2000, 2005, and 2010). The public-supply domestic per capita water-use values used in 2000 (106 gal/d; Marella, 2004), 2005 (95 gal/d; Marella, 2009), 2010 and 2015 (85 gal/d; Marella, 2014, and table 5 herein) were derived from public-supply withdrawals minus deliveries to commercial, industrial, public uses, and other users. The methodology for calculating withdrawals was revised after 1995, because the public-supply gross per capita calculations included commercial, industrial, and public uses (including losses) and other uses (table 5), thus tending to overestimate the water withdrawals for this category. The revised public-supply domestic per capita water-use calculation includes only what is used for households (including both indoor and outdoor uses) and, therefore, provides a better estimate of water withdrawals for this category.

\section{Commercial-Industrial-Mining Self-Supplied}

Commercial-industrial-mining self-supplied use refers to water withdrawn directly by commercial, industrial, and mining facilities. Commercial users include some self-supplied

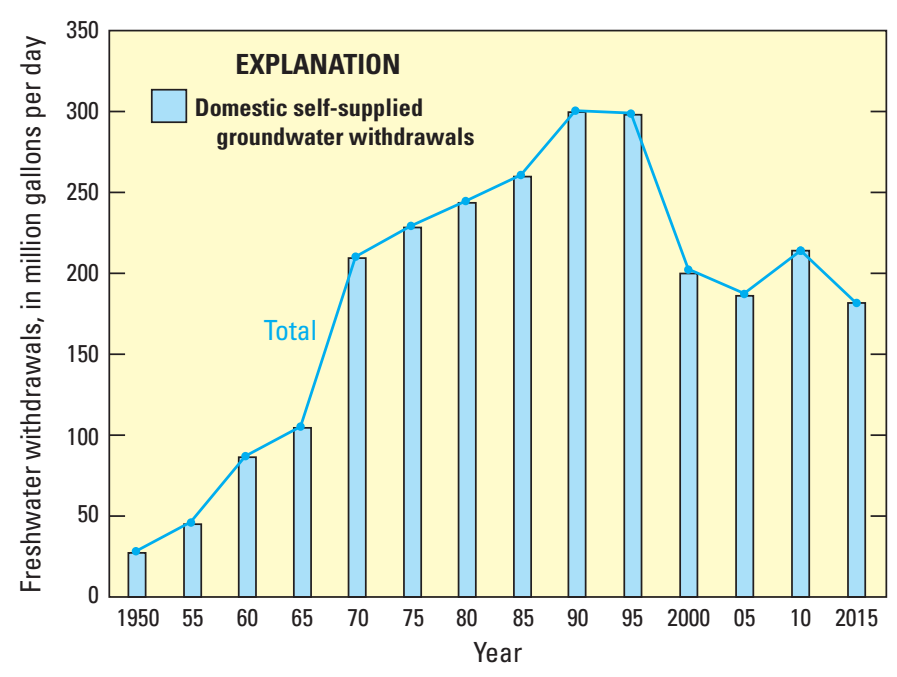

Figure 10. Historical domestic self-supplied groundwater withdrawals in Florida, 1950-2015. Modified from Marella (2014). community water systems, such as government and military facilities, schools, prisons, hospitals, and recreational facilities (nonirrigation), as well as nontransient noncommunity and transient noncommunity water systems that include places such as churches, restaurants, theme parks, and nonmanufacturing facilities. Industrial users include processing and manufacturing facilities, whereas mining use includes conveyance, dust control, extraction, milling, washing, and periodic dewatering. Data for this report were obtained for those self-supplied commercial, industrial, or mining users having withdrawals totaling more than $0.01 \mathrm{Mgal} / \mathrm{d}$. Most nontransient noncommunity and transient noncommunity water systems do not meet this minimum threshold.

Water withdrawals by the inventoried commercialindustrial-mining self-supplied systems in Florida totaled $412 \mathrm{Mgal} / \mathrm{d}$ in 2015 (table 7). Groundwater supplied $298 \mathrm{Mgal} / \mathrm{d}$ (72 percent) and surface water supplied $114 \mathrm{Mgal} / \mathrm{d}$ (28 percent) of water withdrawals, which includes $3 \mathrm{Mgal} / \mathrm{d}$ of saline water. In addition, another $600 \mathrm{Mgal} / \mathrm{d}$ was delivered to commercial (524 Mgal/d) and industrial (76 Mgal/d) users from public-supply water systems in 2015 (table 5). Another $68 \mathrm{Mgal} / \mathrm{d}$ of reclaimed wastewater was also used for this category in 2015 (Florida Department of Environmental Protection, 2016).

Groundwater and surface-water withdrawals for commercial-industrial-mining self-supplied use were derived from various fresh and saline sources. Groundwater withdrawal sources for this category include the Floridan aquifer system (75 percent), followed by the Biscayne aquifer (12 percent), the sand and gravel aquifer system (9 percent), and the intermediate aquifer system and surficial aquifer system (2 percent each). Major surface-water sources for commercial-industrial-mining self-supplied use include tributaries to Rice Creek in Putnam County and the Escambia River in Escambia County (each at 21 percent; water features shown in fig. 2). A large proportion of the remaining surface-water withdrawals in this category were from unnamed mining pits or ponds used for dewatering and other mining operations. The largest total freshwater withdrawals for commercial-industrial-mining self-supplied purposes were in Escambia County, followed by Miami-Dade, Polk, Taylor, Nassau, and Putnam Counties (table 7). These six counties accounted for more than half ( 58 percent) of the water withdrawals in this category during 2015. In addition, a small amount of saline surface water was withdrawn for industrial cooling purposes in Nassau County during 2015 (table 7).

Pulp and paper manufacturing accounted for the largest percentage of freshwater used in the commercial-industrialmining self-supplied category (36 percent), followed by mining (32 percent) (fig. 11). The pulp and paper industry is located in northern and western Florida, where the State is heavily forested, whereas mining operations are located throughout Florida but mostly concentrated in the central and extreme southeastern and southwestern parts of the State. Water withdrawals by the mining industry are primarily for material washing and conveyance, but often include water 
Table 7. Commercial-industrial-mining self-supplied water withdrawals in Florida by county, 2015.

[Data compiled during this study are available as a U.S. Geological Survey data release (Marella and Dixon, 2018). All values in million gallons per day]

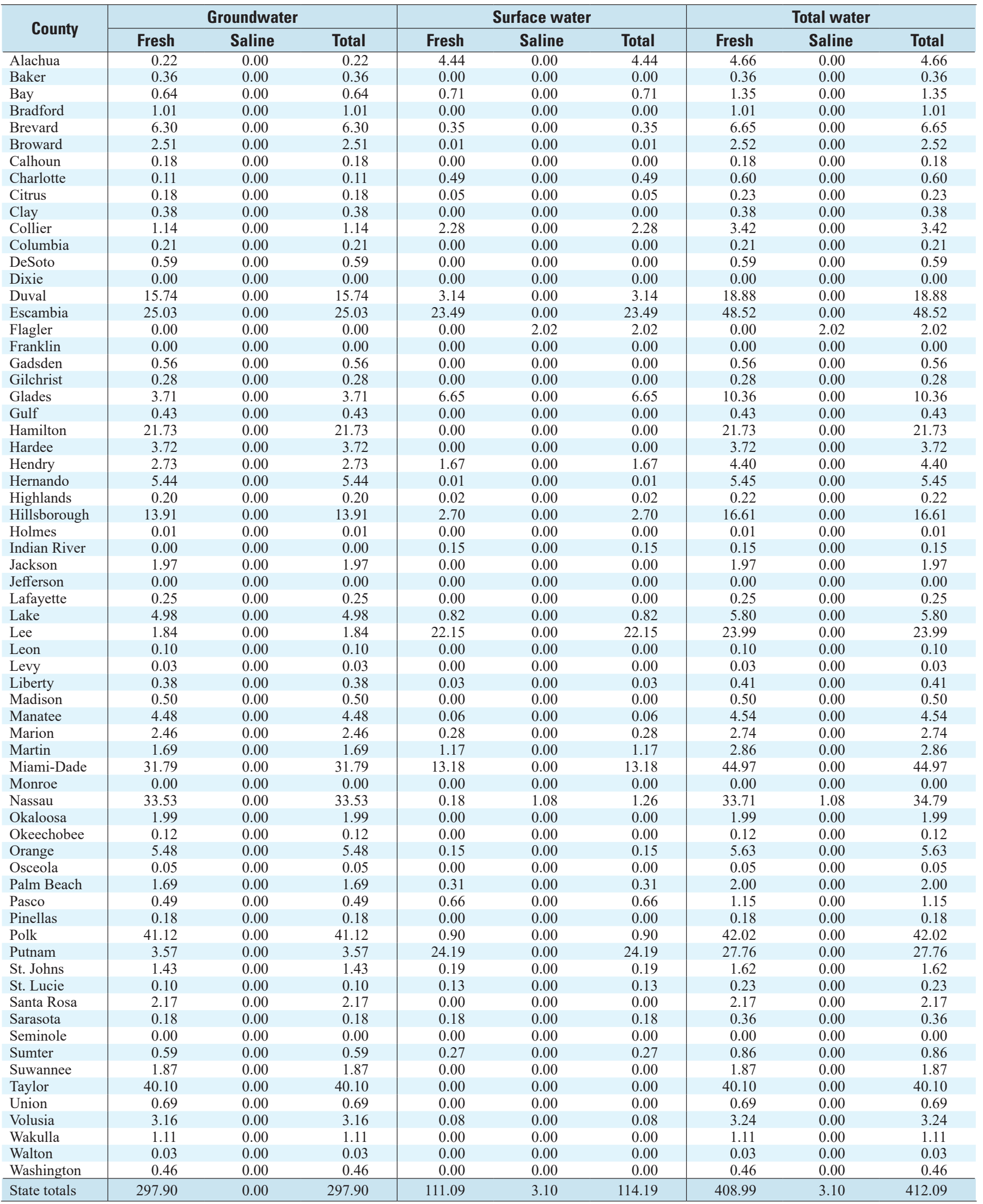




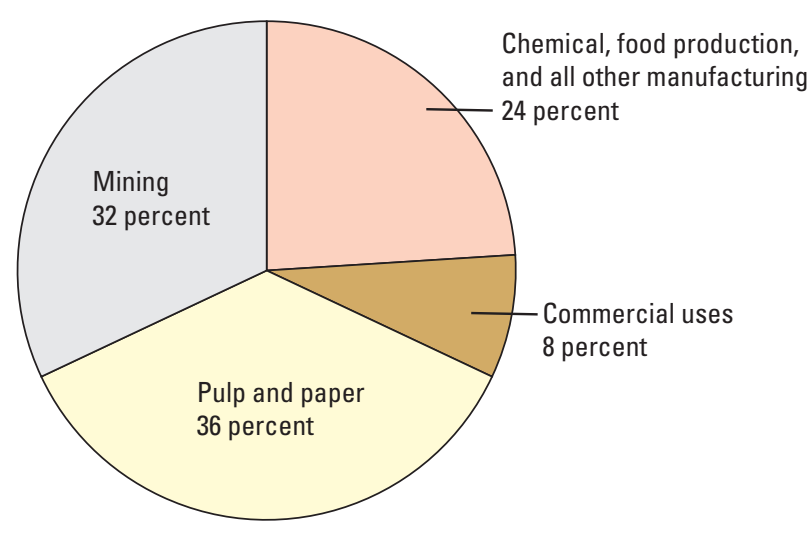

Figure 11. Commercial-industrial-mining self-supplied freshwater use in Florida by major industrial type, 2015.

pumped to dewater the area being mined. Food production (including water-bottling) accounted for about $20 \mathrm{Mgal} / \mathrm{d}$ of the freshwater withdrawals in this category in 2015, of which about one-quarter (5 Mgal/d) was withdrawn specifically for water-bottling. However, the majority of water bottlers (64 percent nationally) obtain their water for bottling from a public-supply water system (Felton, 2019) and would be accounted for as industrial deliveries under public supply. Water withdrawals from the inventoried self-supplied commercial users, such as hospitals, prisons, schools, and theme parks, accounted for 8 percent ( $34 \mathrm{Mgal} / \mathrm{d}$ ) of the freshwater withdrawals in this category in 2015 (fig. 11). Water withdrawals for the Reedy Creek Improvement District (15 Mgal/d), which primarily serves a transient population associated with the theme parks and resorts in southwestern Orange County, were moved from the commercialindustrial-mining self-supplied category and added to the public-supply category in 2015 , because they also serve a permanent population.

Freshwater withdrawals for commercial-industrial-mining self-supplied use in Florida decreased from 1990 to 2010 and then increased 9 percent from 2010 to 2015 (fig. 12). This pattern reflects that of manufacturing employment in Florida, as the number of employees in manufacturing decreased from 0.511 million in 1990 to 0.271 million in 2010 but increased to 0.298 million in 2015 (U.S. Census Bureau, 1992, 2012, 2017). The long-term decline was caused by downsizing or closures of several large chemical plants, pulp mills, and other manufacturing facilities in Florida (Coastal, 2006; Nelson, 2006). More recently, however, mining and production of lime rock and sand have increased as new homes, commercial facilities (heath facilities, hotels, restaurants, shopping areas), and road construction have increased statewide since 2010 (U.S. Geological Survey, 2018). Another longer trend in the data indicates that while self-supplied withdrawals for this category are decreasing overall, deliveries from public supply to commercial users have increased over time, whereas deliveries to industrial users have decreased

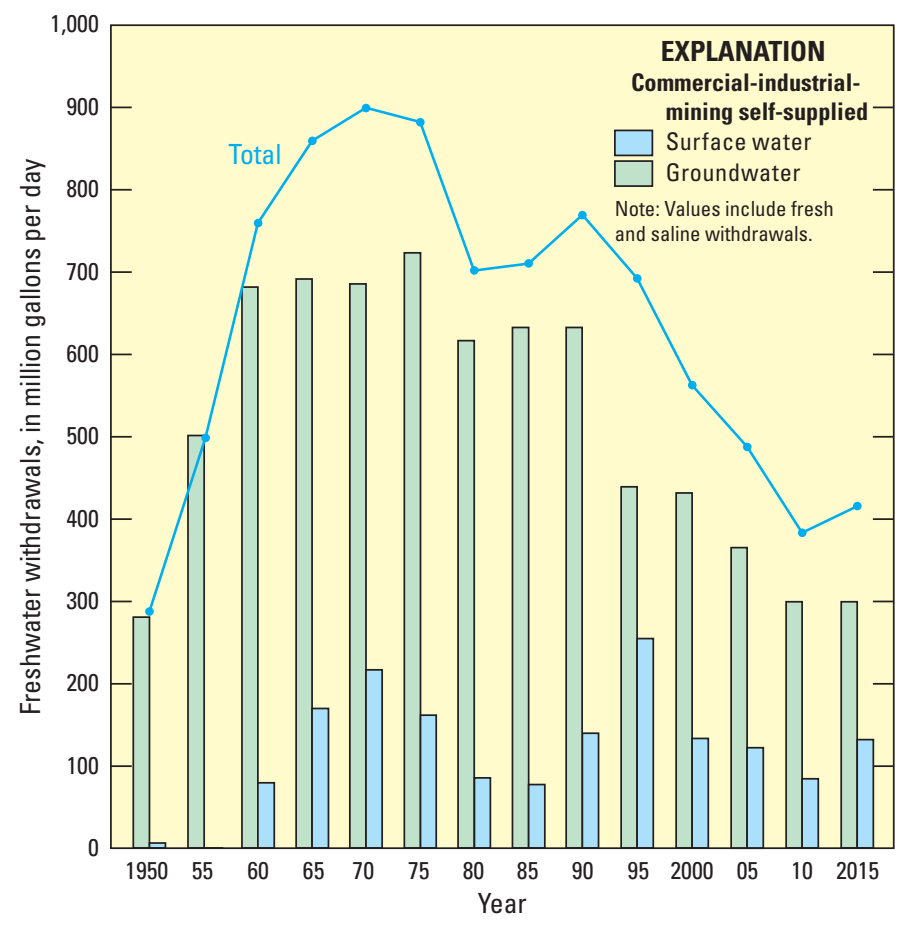

Figure 12. Historical commercial-industrial-mining self-supplied freshwater withdrawals in Florida by source, 1950-2015. Modified from Marella (2014).

over time. From 1990 to 2015, deliveries of public-supply water to commercial users increased from 282 to $524 \mathrm{Mgal} / \mathrm{d}$, while deliveries to industrial users decreased from $183 \mathrm{Mgal} / \mathrm{d}$ (Marella, 1992) to $76 \mathrm{Mgal} / \mathrm{d}$ (table 5). The statewide trend of increasing employment in the service industries, mainly commercial establishments, has helped increase commercial deliveries, whereas decreasing employment in manufacturing has helped decrease industrial deliveries. Most new commercial establishments, such as health facilities, hotels, restaurants, and shopping areas, are being built in areas throughout the State that are most likely served by a public-supply water system.

\section{Agricultural Self-Supplied (Irrigation and Nonirrigation)}

Agricultural self-supplied use refers to water withdrawn for crop irrigation and for nonirrigation uses associated with agricultural and farming operations. Crop irrigation includes the application of water on lands to assist in cultivation of crops or to prevent crop damage caused by harsh weather conditions. Nonirrigation uses include withdrawals for livestock watering, washing of dairy and farm equipment, augmenting or flushing ponds used for fish farming, and other farm uses. Water withdrawals for this category are calculated using acres irrigated for selected crops by county, multiplied by an application rate (that includes an efficiency rate for each type of irrigation system) by crop type. 
Agricultural self-supplied was the second largest freshwater-use category in Florida, accounting for 37 percent of the statewide total freshwater withdrawals in 2015 (fig. 4). Water withdrawals for agricultural self-supplied use in Florida totaled 2,089 Mgal/d for 2015 (table 8). All water withdrawals for irrigation in Florida were assumed to be freshwater. Surface water supplied 52 percent $(1,078 \mathrm{Mgal} / \mathrm{d})$ and groundwater supplied 48 percent $(1,011 \mathrm{Mgal} / \mathrm{d})$ of the water withdrawn in this category (table 8). An additional $64 \mathrm{Mgal} / \mathrm{d}$ of reclaimed wastewater was used for irrigation purposes in Florida during 2015 (Florida Department of Environmental Protection, 2016). Overall, the water used for crop irrigation (2,050 Mgal/d) accounted for 98 percent of the water withdrawn in this category for 2015 , and the nonirrigation uses for livestock (26 Mgal/d) and aquaculture-fish farming (13 Mgal/d) accounted for the remaining 2 percent.

The Floridan aquifer system supplied 70 percent of the groundwater withdrawn for agricultural self-supplied use in 2015 . The remaining 30 percent was obtained from other aquifers, such as the intermediate aquifer system (15 percent), surficial aquifer system (12 percent), Biscayne aquifer (2.5 percent), and sand and gravel aquifer system ( 0.5 percent). Major sources of surface water for irrigation purposes include the canals associated with the Caloosahatchee River and Lake Okeechobee (Glades, Hendry, Martin, Palm Beach, and St. Lucie Counties), and the many unnamed canals in these counties (fig. 6). The Southern Florida Subregion, a hydrologic unit that includes the Everglades Agricultural Area (fig. 6), is intensively irrigated for sugarcane, citrus, vegetables, and sod. The above-named five counties accounted for 93 percent of the surface-water withdrawals for irrigation (table 8).

A key component in estimating agricultural irrigation water use is knowing the acreage of various irrigated crops. However, the availability and reporting of agricultural irrigated acreage data are often incomplete or inconsistent throughout Florida, especially over the past 25 years. In addition, minimal data exist on the type of irrigation systems being used. According to the U.S. Department of Agriculture (USDA), "2012 Census of Agriculture_-Florida State and County Data," the total acreage for agricultural production in Florida was 9.548 million with nearly 16 percent or 1.493 million acres being irrigated (U.S. Department of Agriculture, 2014). Beginning in 2013, the Office of Agricultural Water Policy of FDACS began to estimate total and irrigated acreage by county as part of a statewide planning effort (Balmoral Group, 2011). From the 2015 effort by FDACS, an estimated 21 percent or 1.800 million acres of the total 8.613 million acres of agricultural land in Florida were irrigated (Balmoral Group, 2016). Although this appears to be an increase in irrigated acreage between 2012 and 2015, these values are derived by using different methodologies and therefore are not comparable.

Crop acreage totals are updated each year for selected crops (citrus, field crops, and vegetable) by the USDA
National Agricultural Statistics Service; however, these totals often do not differentiate between total and irrigated acreage. In Florida, pastureland accounts for the majority of agricultural lands, but only a small percentage of pastureland is irrigated across the State. According to the National Agricultural Statistics Service, the three largest crops in Florida other than pastureland for 2015 include citrus (0.501 million acres), sugarcane (0.398 million acres), and vegetables, including all berries and potatoes ( 0.211 million acres) (Florida Department of Agriculture and Consumer Services, 2016). It is assumed that nearly all of the acreage for these crops is irrigated. Other important crops that would be irrigated in Florida include container and tree nurseries, sod, and field crops such as cotton, peanuts, and hay. Beginning in 2013, the FDACS created an irrigated-land-use coverage (FSAID) for all counties in Florida that details the irrigated acreage for nearly all crops grown in Florida. As of the end of 2015, the irrigated crop acreage had been field verified by the USGS or the SJRWMD in 29 counties, and between 2016 and 2019 the irrigated acreage was field verified in another 18 counties.

Hendry, Palm Beach, Collier, Glades, and Martin Counties all withdrew more than $100 \mathrm{Mgal} / \mathrm{d}$ in 2015, and these combined withdrawals accounted for more than half (58 percent) of the total water withdrawals for agricultural self-supplied use statewide (table 8). Palm Beach County was the largest user of surface water, and Hendry County was the largest user of groundwater. Palm Beach County had the greatest sugarcane acreage in Florida, totaling 0.294 million acres. Polk County had the greatest citrus acreage, totaling 0.081 million acres in 2015 , followed by DeSoto (0.066 million acres), Hendry (0.064 million acres), and Highlands (0.058 million acres); combined, these counties accounted for 53 percent of the State's citrus acreage in 2015 (Florida Department of Agriculture and Consumer Services, 2016).

The ability to access large quantities of freshwater for irrigation relatively inexpensively in most areas (Vecchioli and Foose, 1985) coupled with the State's subtropical climate and mild winters allow for early spring crop production and the potential to harvest multiple crops per year. In addition, Florida's proximity to east coast markets and a capability to ship perishable products in a timely fashion created a boom in irrigation in the 1970s, 1980s, and 1990s (Mulkey and Clouser, 1990). During the 1980s, water withdrawals for agricultural irrigation averaged just under 3,000 Mgal/d; in the 1990s, withdrawals averaged about 3,400 Mgal/d; for 2000 , withdrawals peaked at nearly $4,000 \mathrm{Mgal} / \mathrm{d}$ before decreasing to around 2,800 Mgal/d in 2005 and 2,550 Mgal/d in 2010 , to the current value of nearly $2,100 \mathrm{Mgal} / \mathrm{d}$ in 2015. Overall, agricultural self-supplied withdrawals in Florida decreased by 31 percent between 1980 and 2015, by 47 percent between 2000 and 2015, and by 18 percent between 2010 and 2015 (fig. 13). Water withdrawals for agricultural self-supplied use in 2015 were substantially lower 
Table 8. Agricultural self-supplied water withdrawals by in Florida by county, 2015.

[This category includes crop irrigation, aquaculture, and livestock withdrawals. Data compiled during this study are available as a U.S. Geological Survey data release (Marella and Dixon, 2018). All values in million gallons per day]

\begin{tabular}{|c|c|c|c|c|c|c|c|c|c|}
\hline \multirow{2}{*}{ County } & \multicolumn{3}{|c|}{ Groundwater } & \multicolumn{3}{|c|}{ Surface water } & \multicolumn{3}{|c|}{ Total water } \\
\hline & Fresh & Saline & Total & Fresh & Saline & Total & Fresh & Saline & Total \\
\hline Alachua & 15.61 & 0.00 & 15.61 & 0.03 & 0.00 & 0.03 & 15.64 & 0.00 & 15.64 \\
\hline Baker & 0.39 & 0.00 & 0.39 & 0.06 & 0.00 & 0.06 & 0.45 & 0.00 & 0.45 \\
\hline Bay & 1.56 & 0.00 & 1.56 & 0.00 & 0.00 & 0.00 & 1.56 & 0.00 & 1.56 \\
\hline Bradford & 1.76 & 0.00 & 1.76 & 0.01 & 0.00 & 0.01 & 1.77 & 0.00 & 1.77 \\
\hline Brevard & 30.83 & 0.00 & 30.83 & 2.05 & 0.00 & 2.05 & 32.88 & 0.00 & 32.88 \\
\hline Broward & 0.65 & 0.00 & 0.65 & 2.23 & 0.00 & 2.23 & 2.88 & 0.00 & 2.88 \\
\hline Calhoun & 3.10 & 0.00 & 3.10 & 0.14 & 0.00 & 0.14 & 3.24 & 0.00 & 3.24 \\
\hline Charlotte & 6.90 & 0.00 & 6.90 & 5.49 & 0.00 & 5.49 & 12.39 & 0.00 & 12.39 \\
\hline Citrus & 1.41 & 0.00 & 1.41 & 0.02 & 0.00 & 0.02 & 1.43 & 0.00 & 1.43 \\
\hline Clay & 0.41 & 0.00 & 0.41 & 0.76 & 0.00 & 0.76 & 1.17 & 0.00 & 1.17 \\
\hline Collier & 97.21 & 0.00 & 97.21 & 4.67 & 0.00 & 4.67 & 101.88 & 0.00 & 101.88 \\
\hline Columbia & 2.18 & 0.00 & 2.18 & 0.01 & 0.00 & 0.01 & 2.19 & 0.00 & 2.19 \\
\hline DeSoto & 41.60 & 0.00 & 41.60 & 0.25 & 0.00 & 0.25 & 41.85 & 0.00 & 41.85 \\
\hline Dixie & 4.24 & 0.00 & 4.24 & 0.00 & 0.00 & 0.00 & 4.24 & 0.00 & 4.24 \\
\hline Duval & 0.83 & 0.00 & 0.83 & 1.00 & 0.00 & 1.00 & 1.83 & 0.00 & 1.83 \\
\hline Escambia & 2.40 & 0.00 & 2.40 & 0.00 & 0.00 & 0.00 & 2.40 & 0.00 & 2.40 \\
\hline Flagler & 11.19 & 0.00 & 11.19 & 0.11 & 0.00 & 0.11 & 11.30 & 0.00 & 11.30 \\
\hline Franklin & 0.00 & 0.00 & 0.00 & 0.00 & 0.00 & 0.00 & 0.00 & 0.00 & 0.00 \\
\hline Gadsden & 1.38 & 0.00 & 1.38 & 5.36 & 0.00 & 5.36 & 6.74 & 0.00 & 6.74 \\
\hline Gilchrist & 14.22 & 0.00 & 14.22 & 0.05 & 0.00 & 0.05 & 14.27 & 0.00 & 14.27 \\
\hline Glades & 8.76 & 0.00 & 8.76 & 112.39 & 0.00 & 112.39 & 121.15 & 0.00 & 121.15 \\
\hline Gulf & 0.29 & 0.00 & 0.29 & 0.00 & 0.00 & 0.00 & 0.29 & 0.00 & 0.29 \\
\hline Hamilton & 18.38 & 0.00 & 18.38 & 0.02 & 0.00 & 0.02 & 18.40 & 0.00 & 18.40 \\
\hline Hardee & 32.76 & 0.00 & 32.76 & 0.31 & 0.00 & 0.31 & 33.07 & 0.00 & 33.07 \\
\hline Hendry & 122.66 & 0.00 & 122.66 & 256.51 & 0.00 & 256.51 & 379.17 & 0.00 & 379.17 \\
\hline Hernando & 1.50 & 0.00 & 1.50 & 0.03 & 0.00 & 0.03 & 1.53 & 0.00 & 1.53 \\
\hline Highlands & 67.60 & 0.00 & 67.60 & 14.29 & 0.00 & 14.29 & 81.89 & 0.00 & 81.89 \\
\hline Hillsborough & 41.67 & 0.00 & 41.67 & 2.34 & 0.00 & 2.34 & 44.01 & 0.00 & 44.01 \\
\hline Holmes & 1.09 & 0.00 & 1.09 & 0.01 & 0.00 & 0.01 & 1.10 & 0.00 & 1.10 \\
\hline Indian River & 20.75 & 0.00 & 20.75 & 19.25 & 0.00 & 19.25 & 40.00 & 0.00 & 40.00 \\
\hline Jackson & 27.96 & 0.00 & 27.96 & 0.08 & 0.00 & 0.08 & 28.04 & 0.00 & 28.04 \\
\hline Jefferson & 4.03 & 0.00 & 4.03 & 0.24 & 0.00 & 0.24 & 4.27 & 0.00 & 4.27 \\
\hline Lafayette & 9.67 & 0.00 & 9.67 & 0.07 & 0.00 & 0.07 & 9.74 & 0.00 & 9.74 \\
\hline Lake & 27.07 & 0.00 & 27.07 & 1.18 & 0.00 & 1.18 & 28.25 & 0.00 & 28.25 \\
\hline Lee & 14.18 & 0.00 & 14.18 & 5.15 & 0.00 & 5.15 & 19.33 & 0.00 & 19.33 \\
\hline Leon & 0.85 & 0.00 & 0.85 & 0.05 & 0.00 & 0.05 & 0.90 & 0.00 & 0.90 \\
\hline Levy & 15.51 & 0.00 & 15.51 & 0.05 & 0.00 & 0.05 & 15.56 & 0.00 & 15.56 \\
\hline Liberty & 0.07 & 0.00 & 0.07 & 0.00 & 0.00 & 0.00 & 0.07 & 0.00 & 0.07 \\
\hline Madison & 14.30 & 0.00 & 14.30 & 0.03 & 0.00 & 0.03 & 14.33 & 0.00 & 14.33 \\
\hline Manatee & 47.61 & 0.00 & 47.61 & 0.30 & 0.00 & 0.30 & 47.91 & 0.00 & 47.91 \\
\hline Marion & 9.98 & 0.00 & 9.98 & 0.11 & 0.00 & 0.11 & 10.09 & 0.00 & 10.09 \\
\hline Martin & 6.82 & 0.00 & 6.82 & 93.55 & 0.00 & 93.55 & 100.37 & 0.00 & 100.37 \\
\hline Miami-Dade & 24.32 & 0.00 & 24.32 & 0.18 & 0.00 & 0.18 & 24.50 & 0.00 & 24.50 \\
\hline Monroe & 0.00 & 0.00 & 0.00 & 0.00 & 0.00 & 0.00 & 0.00 & 0.00 & 0.00 \\
\hline Nassau & 0.33 & 0.00 & 0.33 & 0.00 & 0.00 & 0.00 & 0.33 & 0.00 & 0.33 \\
\hline Okaloosa & 0.42 & 0.00 & 0.42 & 0.00 & 0.00 & 0.00 & 0.42 & 0.00 & 0.42 \\
\hline Okeechobee & 13.31 & 0.00 & 13.31 & 2.06 & 0.00 & 2.06 & 15.37 & 0.00 & 15.37 \\
\hline Orange & 6.21 & 0.00 & 6.21 & 0.28 & 0.00 & 0.28 & 6.49 & 0.00 & 6.49 \\
\hline Osceola & 9.86 & 0.00 & 9.86 & 2.25 & 0.00 & 2.25 & 12.11 & 0.00 & 12.11 \\
\hline Palm Beach & 4.75 & 0.00 & 4.75 & 512.52 & 0.00 & 512.52 & 517.27 & 0.00 & 517.27 \\
\hline Pasco & 6.36 & 0.00 & 6.36 & 0.07 & 0.00 & 0.07 & 6.43 & 0.00 & 6.43 \\
\hline Pinellas & 0.01 & 0.00 & 0.01 & 0.02 & 0.00 & 0.02 & 0.03 & 0.00 & 0.03 \\
\hline Polk & 77.94 & 0.00 & 77.94 & 3.24 & 0.00 & 3.24 & 81.18 & 0.00 & 81.18 \\
\hline Putnam & 21.16 & 0.00 & 21.16 & 0.05 & 0.00 & 0.05 & 21.21 & 0.00 & 21.21 \\
\hline St. Johns & 37.44 & 0.00 & 37.44 & 0.14 & 0.00 & 0.14 & 37.58 & 0.00 & 37.58 \\
\hline St. Lucie & 12.41 & 0.00 & 12.41 & 26.71 & 0.00 & 26.71 & 39.12 & 0.00 & 39.12 \\
\hline Santa Rosa & 1.41 & 0.00 & 1.41 & 0.00 & 0.00 & 0.00 & 1.41 & 0.00 & 1.41 \\
\hline Sarasota & 3.67 & 0.00 & 3.67 & 0.35 & 0.00 & 0.35 & 4.02 & 0.00 & 4.02 \\
\hline Seminole & 2.81 & 0.00 & 2.81 & 0.00 & 0.00 & 0.00 & 2.81 & 0.00 & 2.81 \\
\hline Sumter & 6.23 & 0.00 & 6.23 & 0.10 & 0.00 & 0.10 & 6.33 & 0.00 & 6.33 \\
\hline Suwannee & 30.39 & 0.00 & 30.39 & 0.14 & 0.00 & 0.14 & 30.53 & 0.00 & 30.53 \\
\hline Taylor & 0.05 & 0.00 & 0.05 & 0.00 & 0.00 & 0.00 & 0.05 & 0.00 & 0.05 \\
\hline Union & 1.25 & 0.00 & 1.25 & 0.01 & 0.00 & 0.01 & 1.26 & 0.00 & 1.26 \\
\hline Volusia & 17.11 & 0.00 & 17.11 & 1.75 & 0.00 & 1.75 & 18.86 & 0.00 & 18.86 \\
\hline Wakulla & 0.34 & 0.00 & 0.34 & 0.00 & 0.00 & 0.00 & 0.34 & 0.00 & 0.34 \\
\hline Walton & 0.79 & 0.00 & 0.79 & 0.04 & 0.00 & 0.04 & 0.83 & 0.00 & 0.83 \\
\hline Washington & 0.72 & 0.00 & 0.72 & 0.02 & 0.00 & 0.02 & 0.74 & 0.00 & 0.74 \\
\hline State totals & $1,010.67$ & 0.00 & $1,010.67$ & $1,078.13$ & 0.00 & $1,078.13$ & $2,088.80$ & 0.00 & $2,088.80$ \\
\hline
\end{tabular}


than during most of the previous 30 years (fig. 13). The more recent decrease can be attributed to several factors:

- Large losses of irrigated acreage as disease (such as citrus canker and greening), storm damage (primarily from hurricanes), and urbanization affected many agricultural areas across the State between 2000 and 2015 (White and van Blokland, 2006). Citrus acreage alone decreased 40 percent statewide, from 0.832 million acres in 2000 to 0.501 million acres in 2015 and further to 0.488 million acres in 2016 (fig. 14; Florida Department of Agriculture and Consumer Services, 2016, 2017).

- Higher rainfall for 2010 and 2015 compared to 2000, as the annual average statewide rainfall in 2000 was $43 \mathrm{in}$., compared to nearly $49 \mathrm{in}$. for 2010 and $53 \mathrm{in.}$ for 2015 (Florida State University, 2017). Water demand was substantially higher in 2000 because of lower than normal rainfall, which was especially critical during certain times of the year.

- A collaborative effort over the past 10-15 years by many agencies (FDACS, FDEP, University of Florida Institute of Food and Agriculture Science, USDA, and the five WMDs) to increase irrigation efficiencies, promote water conservation, and encourage better water management practices throughout the State to better protect local water levels and quality.

- Better knowledge of the coefficients used to calculate withdrawals over the past 10-15 years as rainfall and evapotranspiration values are available at a local level, coupled with the availability of monthly and annual metered data from thousands of irrigators statewide that help calibrate or set application rates from irrigation models.

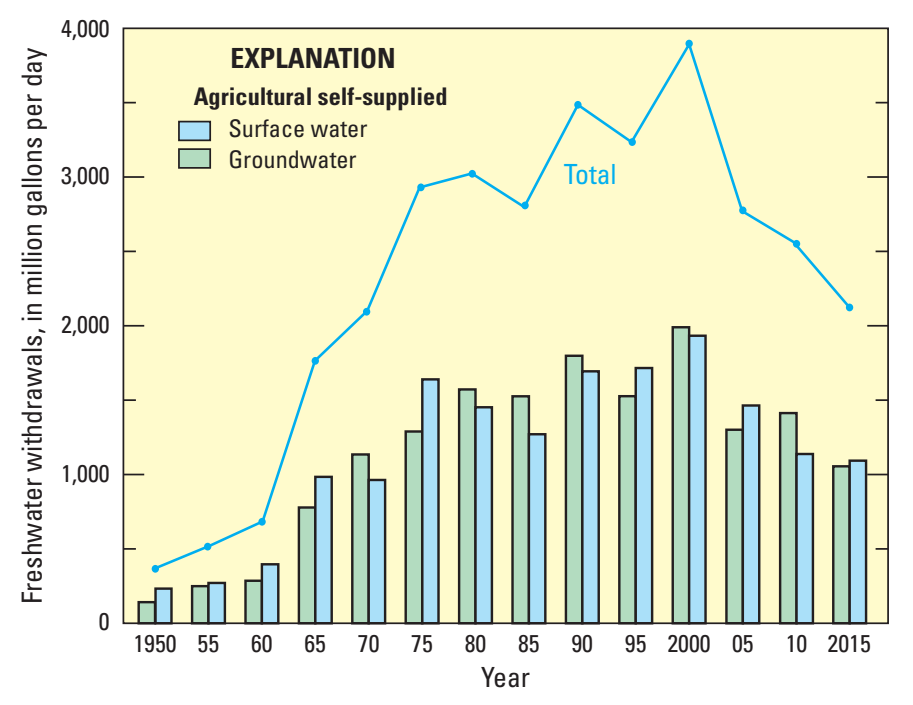

Figure 13. Historical agricultural self-supplied freshwater withdrawals in Florida by source, 1950-2015. Modified from Marella (2014).

\section{Recreational-Landscape Irrigation}

Recreational-landscape irrigation use includes the application of water on lands to assist in growing turfgrass (not including sod) and landscape vegetation for lawns or recreational purposes, and also includes water used for aesthetic purposes. Recreational irrigation includes golf course irrigation, including all grass and landscape associated with golf courses. Landscape irrigation includes the irrigation of turfgrass and other vegetation associated with athletic fields, cemeteries, common public or highway areas, parks, playgrounds, school grounds, and nonresidential lawns and grasses primarily associated with commercial establishments. This category does not include withdrawal estimates for lawn or landscape irrigation from private wells or surface-water bodies. Aesthetic uses are associated with water used to fill or maintain nonagricultural lakes, ponds, and fountains.

Water used for recreational-landscape irrigation may be obtained from a public water supplier, including reclaimed wastewater, or may be self-supplied. The values presented in this section represent the water withdrawn by self-supplied users. Water withdrawals for this category are calculated using acreage irrigated multiplied by an application rate (that includes an efficiency rate for each type of irrigation system) specific to foliage or grass, with a few exceptions; however, in many cases the metered usage data are used to provide or verify an application rate, which helps increase the accuracy of the water withdrawals for this category.

Water withdrawals for recreational-landscape irrigation in Florida totaled $398 \mathrm{Mgal} / \mathrm{d}$ in 2015 (table 9). All water withdrawals for recreational-landscape irrigation in Florida were assumed to be freshwater. Surface water supplied 54 percent $(216 \mathrm{Mgal} / \mathrm{d})$ of the water withdrawn for recreational-landscape irrigation, and groundwater supplied the remaining 46 percent $(182 \mathrm{Mgal} / \mathrm{d})$. An additional

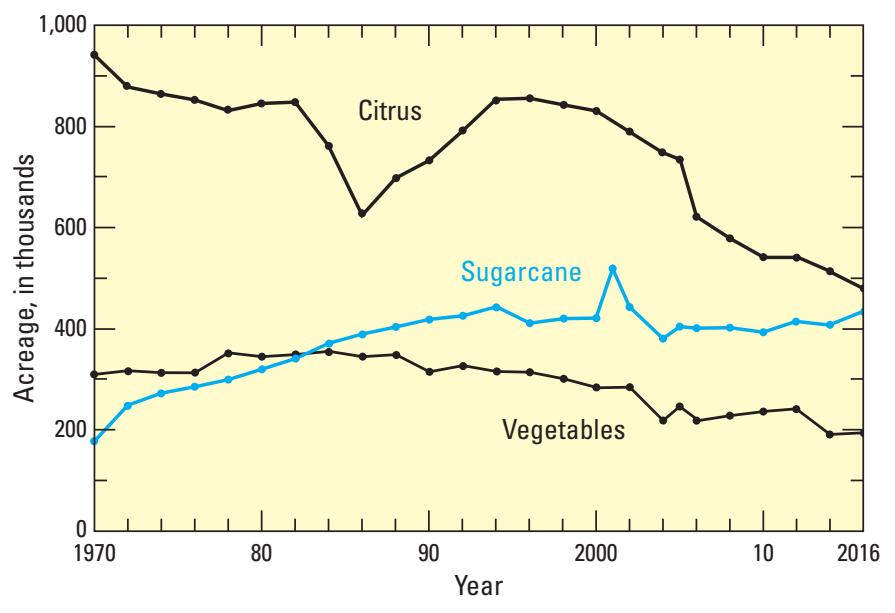

Figure 14. Historical agricultural acreage in Florida for selected crops, 1970-2016. Modified from Marella (2014), U.S. Department of Agriculture (2009, 2014), and Florida Department of Agriculture and Consumer Services $(2016,2017)$. 
Table 9. Recreational-landscape irrigation water withdrawals in Florida by county, 2015.

[Data compiled during this study are available as a U.S. Geological Survey data release (Marella and Dixon, 2018). All values in million gallons per day]

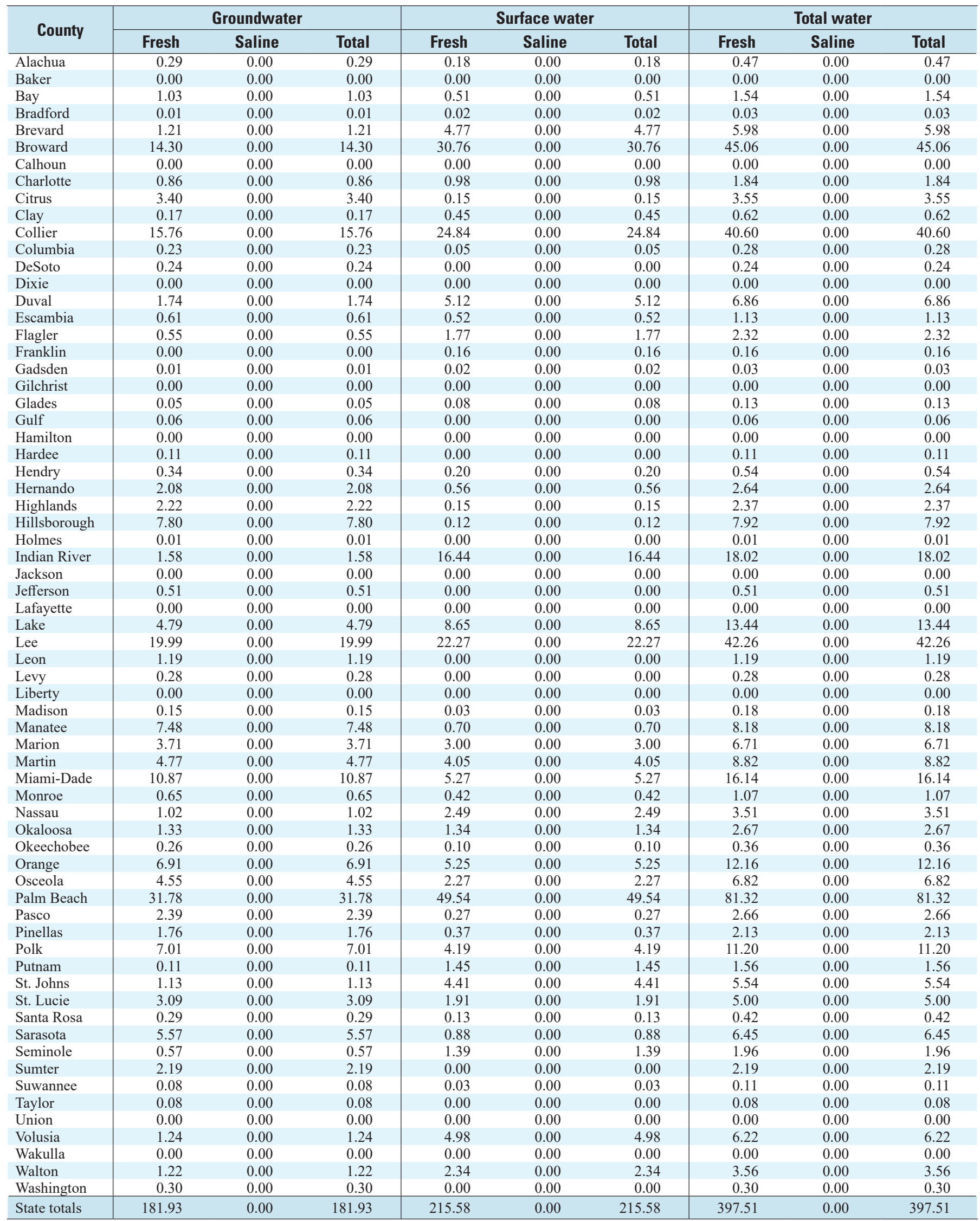


$227 \mathrm{Mgal} / \mathrm{d}$ of reclaimed wastewater was used in 2015 for recreational-landscape irrigation purposes, not including water used for household lawn watering (Florida Department of Environmental Protection, 2016). Groundwater withdrawals were predominantly obtained from the Floridan aquifer system (43 percent), followed by the surficial aquifer system (30 percent), Biscayne aquifer (14.5 percent), intermediate aquifer system (12 percent), and sand and gravel aquifer system ( 0.5 percent). Surface-water sources for this category include local ponds, lakes, and canals. In many cases, surface-water sources are augmented with groundwater or reclaimed wastewater, or they are designed to capture onsite runoff from unused irrigation water and rainfall to maintain water levels or storage for future irrigation needs (Golf Course Superintendents Association of America, 2009). Nearly 53 percent of water withdrawals for recreational-landscape irrigation occurred in Palm Beach, Broward, Lee, and Collier Counties (table 9). For these counties and others in central and southern Florida, recreational-landscape irrigation typically occurs year round, whereas in areas of northern Florida, this type of irrigation is more seasonal. Orange and Palm Beach Counties were the largest users of reclaimed wastewater for recreational-landscape irrigation in 2015 (Florida Department of Environmental Protection, 2016).

Water withdrawals for recreational-landscape irrigation were from fresh groundwater or surface-water sources, or were obtained from reclaimed water sources. Water withdrawn for golf course irrigation totaled about $198 \mathrm{Mgal} / \mathrm{d}$ and an additional $131 \mathrm{Mgal} / \mathrm{d}$ of reclaimed wastewater was used for golf course irrigation in 2015 (Florida Department of Environmental Protection, 2016). Much of the reclaimed wastewater was directly applied for irrigation and some of it was used to augment golf course irrigation ponds or retention areas. Statewide, an estimated 0.120 million acres of golf course turf and associated acres were irrigated in 2015. The remaining recreational-landscape irrigation withdrawals (200 Mgal/d) and reclaimed wastewater $(96 \mathrm{Mgal} / \mathrm{d})$ were used to irrigate an estimated 0.152 million acres of landscaped areas, including grass or shrubs associated with commercial and industrial establishments, highway medians, parks, schools, and public common areas. The actual landscape water withdrawals and acreage in Florida are believed to be much larger than the values reported herein, because most of the users in this category are small and are often accounted for under a general water-use permit rather than a consumptive water-use permit.

Total freshwater withdrawals for recreational-landscape irrigation increased 119 percent between 1985 (when this category was separated from agriculture irrigation) and 2015 (fig. 15). Recently, total freshwater withdrawals for recreational-landscape irrigation decreased 3 percent between 2000 and 2015 but increased slightly more than 1 percent between 2010 and 2015. The decline in withdrawals across Florida between 2000 and 2015 is believed to be a result of three factors:

- Loss of urban golf course acreage caused by an increase in the value of the land these facilities reside on over the past 10 years and the subsequent conversion of many golf courses to housing communities. Between 2000 and 2015, there was a net reduction of golf course acreage equivalent to 22 golf courses statewide (Greg Nathan, the National Golf Foundation, written commun., September 12, 2016).

- Abandonment or closure of many golf courses stemming from the increased maintenance and operating cost, coupled with a decrease in the number of new players since 2000 (Chad Barton, the Golf Group, written commun., September 13, 2013).

- Higher rainfall for 2010 and 2015 compared to 2000, as the annual average statewide rainfall in 2000 was 43 in., compared to nearly 49 in. for 2010 and 53 in. for 2015 (Florida State University, 2017).

The increase in withdrawals for recreational-landscape irrigation across Florida between 2010 and 2015 is believed to be a result of two factors:

- A better economy, which has resulted in an increased number of commercial facilities (health centers, hotels, office parks, and schools) being built, most with landscaping water needs.

- Increases in water costs and restrictions associated with obtaining water from a public supply to irrigate large commercial landscaped areas, which might have resulted in an increase in the number of wells drilled and (or) the number of canals, lakes, and ponds tapped that are being used for irrigation needs and are reported within this category.

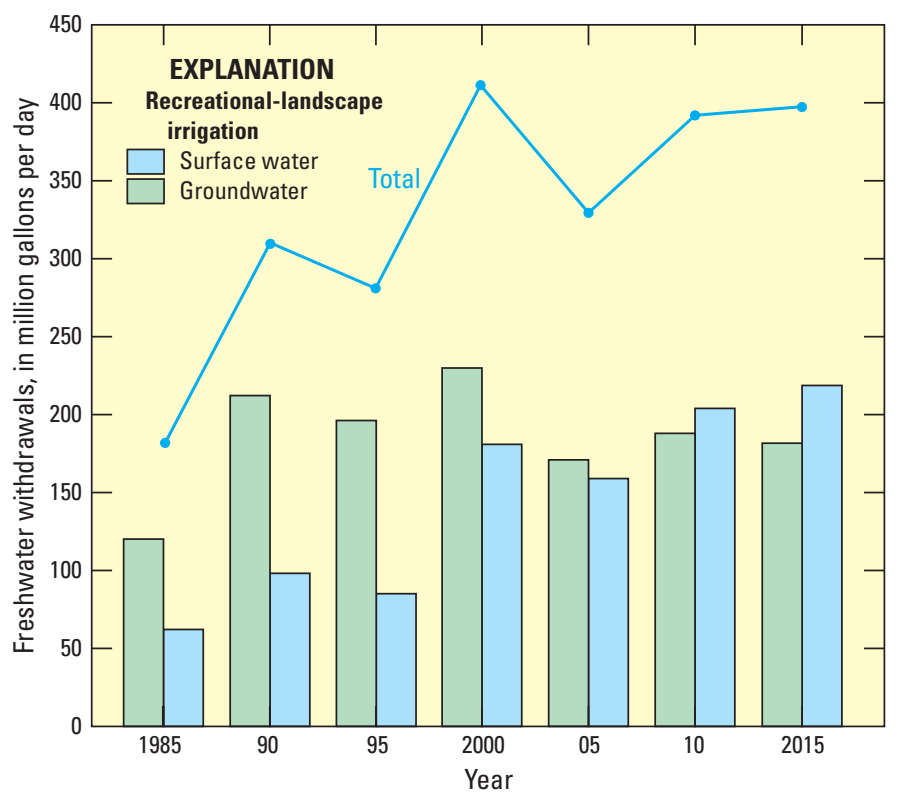

Figure 15. Historical recreational-landscape irrigation freshwater withdrawals in Florida by source, 1985-2015. Modified from Marella (2014). 


\section{Power Generation}

Water used for power generation includes water withdrawals for thermoelectric power generation facilities (fossil fuel, nuclear, and biomass) and water used at hydroelectric facilities. A total of 70 active power-generation facilities in Florida were inventoried for this report. These powerplants range from big facilities with multiple turbine units onsite that generate large amounts of power to small facilities that generate electricity as a byproduct of their main function (such as landfills). Two hydroelectric power-generating facilities were in operation in Florida (in Gadsden and Leon Counties) in 2015, and neither the amount of power generated nor the amount of water that passed through their turbines is reported herein. Water withdrawal data for power generation were collected for fresh and saline sources of groundwater and surface water. In addition, reclaimed wastewater is reported for direct cooling purposes or to augment ponds or reservoirs used for cooling purposes.

Water used for power generation in Florida is withdrawn (1) to condense or cool the steam used to drive thermoelectric turbines and (2) for internal plant uses. In broad terms, two types of technologies are used to cool the steam used to drive turbines: once-through cooling and recirculating cooling. For once-through cooling, water is withdrawn, routed through the condenser to cool the steam, and returned back to the water source. This once-through water can either be fresh or saline but is exclusively from surface-water sources in Florida because of the high volume needed, plus water quality is not an issue. Generally, there is little consumption associated with once-through cooling, as nearly all of the water is returned to its original source with only a fraction of water lost (Diehl and Harris, 2014). Recirculating cooling technologies include cooling towers and cooling ponds or reservoirs. In recirculating cooling systems, water is routed between the cooling system (tower or pond) and the condenser in a closed loop. Much less water is withdrawn than for a once-through cooling system, but more of the water is consumed by evaporation. Water used for recirculating cooling is usually from freshwater sources (ground or surface) or obtained from public supply or reclaimed water sources. At many power generation facilities across Florida, an onsite pond or reservoir is used for recirculating purposes. Approximately 70 percent of the water withdrawn for cooling towers is consumed, whereas water withdrawn for cooling ponds or reservoirs to augment water levels is 100 percent consumed (Diehl and Harris, 2014). Internal plant uses include water withdrawn for domestic uses, cleaning and washdown, and for boiler makeup (water added to the closed loop steam supply). Little of this water is returned, therefore this use is generally considered consumed. Water used within the powerplant facility is freshwater and is either obtained from onsite wells or from a public water-supply system.

Water withdrawals for power generation in Florida totaled 9,859 Mgal/d in 2015 (table 10), of which saline water composed 9,425 Mgal/d (96 percent) and freshwater composed $434 \mathrm{Mgal} / \mathrm{d}$ (4 percent) (table 10). Nearly all (99.7 percent) of the saline-water withdrawals were from surface-water sources; of the freshwater withdrawals, 94 percent were from surface-water sources and 6 percent were from groundwater sources. Overall, nearly 95 percent $(9,396 \mathrm{Mgal} / \mathrm{d})$ of the total surface water (fresh and saline) withdrawn for power generation in 2015 was used for once-through cooling purposes, and nearly all of this water ( 99.9 percent) was returned to its source after use. More than 201,900 gigawatthours (GWh) of total net power were generated by the 70 inventoried facilities in Florida during 2015 (Dieter and others, 2018a). Fresh- and saline-water withdrawals for power generation represent 64 percent of all water withdrawals in Florida for 2015 (table 1).

Most of the surface water used for power generation was withdrawn from coastal water bodies, which included the Anclote River (Pasco County), Caloosahatchee River (Lee County), Crystal River and the Gulf of Mexico (Citrus County), Escambia River (Escambia County), the Indian River (also referred to as the "Intracoastal Waterway" in Brevard, Indian River, and St. Lucie Counties), the St. Johns River (Duval and Putnam Counties), and Tampa Bay (Hillsborough and Pinellas Counties) (figs. 2 and 6). Although several of these water bodies are considered freshwater, the point of withdrawal commonly is tidally influenced, and the water may be fresh, brackish, or saline because of tidal flow (McPherson and Hammett, 1991). Water withdrawals reported herein are considered saline at most of the plants unless they are permitted by the WMDs as freshwater. (Not all power generation facilities have, or are required to have, a consumptive water-use permit from a WMD.) The Floridan aquifer system was the source of 80 percent $(51 \mathrm{Mgal} / \mathrm{d}$ ) of the groundwater withdrawn (fresh and saline) for power generation in 2015. Escambia County accounted for the largest amount of freshwater withdrawn (173 Mgal/d) for power generation in 2015, and Pasco County accounted for the largest amount of saline water withdrawn (1,484 Mgal/d) (table 10).

Total water withdrawals for power generation increased steadily between 1955 and 1980, when withdrawals peaked at nearly 16,000 Mgal/d (fig. 16); however, withdrawals have generally decreased since then. Over the past 25 years, as a result of increased oil prices and the availability of new technology, the power industry in Florida has begun to build predominately natural-gas-fired combined-cycle power turbines at new plants and has retooled existing facilities with this new technology (Ron Hix, Florida Power and Light, written commun., 2014). The combined cycle consists of one or more combustion turbines and one or more boilers with a portion of the required energy input to the boilers provided by the exhaust gas of the main combustion turbine (U.S. Energy Information Administration, n.d.). Retooling typically involves changing both the power generation source from conventional fossil fuel (oil and coal) turbines to the combined-cycle power generation technology using natural gas. In 2015, natural gas supplied about 58 percent of the fuel used to generate power in Florida compared to about 20 percent in 2000 (U.S. Energy Information Administration, 2018). This conversion increased power generation capacity and water efficiency while lowering fuel consumption and emitting fewer pollutants (Ron Hix, Florida Power and Light, written commun., 2014). As a result 
Table 10. Power generation water withdrawals in Florida by county, 2015.

[Data compiled during this study are available as a U.S. Geological Survey data release (Marella and Dixon, 2018). All values in million gallons per day]

\begin{tabular}{|c|c|c|c|c|c|c|c|c|c|}
\hline \multirow{2}{*}{ County } & \multicolumn{3}{|c|}{ Groundwater } & \multicolumn{3}{|c|}{ Surface water } & \multicolumn{3}{|c|}{ Total water } \\
\hline & Fresh & Saline & Total & Fresh & Saline & Total & Fresh & Saline & Total \\
\hline Alachua & 2.00 & 0.00 & 2.00 & 0.00 & 0.00 & 0.00 & 2.00 & 0.00 & 2.00 \\
\hline Baker & 0.00 & 0.00 & 0.00 & 0.00 & 0.00 & 0.00 & 0.00 & 0.00 & 0.00 \\
\hline Bradford & 0.00 & 0.00 & 0.00 & 0.00 & 0.00 & 0.00 & 0.00 & 0.00 & 0.00 \\
\hline Brevard & 0.06 & 0.00 & 0.06 & 0.00 & 518.79 & 518.79 & 0.06 & 518.79 & 518.85 \\
\hline Broward & 0.00 & 0.00 & 0.00 & 0.00 & 379.78 & 379.78 & 0.00 & 379.78 & 379.78 \\
\hline Calhoun & 0.00 & 0.00 & 0.00 & 0.00 & 0.00 & 0.00 & 0.00 & 0.00 & 0.00 \\
\hline Clay & 0.00 & 0.00 & 0.00 & 0.00 & 0.00 & 0.00 & 0.00 & 0.00 & 0.00 \\
\hline Collier & 0.00 & 0.00 & 0.00 & 0.00 & 0.00 & 0.00 & 0.00 & 0.00 & 0.00 \\
\hline Columbia & 0.00 & 0.00 & 0.00 & 0.00 & 0.00 & 0.00 & 0.00 & 0.00 & 0.00 \\
\hline DeSoto & 0.00 & 0.00 & 0.00 & 0.00 & 0.00 & 0.00 & 0.00 & 0.00 & 0.00 \\
\hline Dixie & 0.00 & 0.00 & 0.00 & 0.00 & 0.00 & 0.00 & 0.00 & 0.00 & 0.00 \\
\hline Duval & 6.43 & 0.00 & 6.43 & 0.00 & 646.10 & 646.10 & 6.43 & 646.10 & 652.53 \\
\hline Escambia & 2.02 & 0.00 & 2.02 & 171.46 & 0.00 & 171.46 & 173.48 & 0.00 & 173.48 \\
\hline Gulf & 0.00 & 0.00 & 0.00 & 0.00 & 0.00 & 0.00 & 0.00 & 0.00 & 0.00 \\
\hline Hamilton & 0.00 & 0.00 & 0.00 & 0.00 & 0.00 & 0.00 & 0.00 & 0.00 & 0.00 \\
\hline Hardee & 0.29 & 0.00 & 0.29 & 0.00 & 0.00 & 0.00 & 0.29 & 0.00 & 0.29 \\
\hline Hendry & 0.00 & 0.00 & 0.00 & 0.00 & 0.00 & 0.00 & 0.00 & 0.00 & 0.00 \\
\hline Hernando & 0.00 & 0.00 & 0.00 & 0.00 & 0.00 & 0.00 & 0.00 & 0.00 & 0.00 \\
\hline Highlands & 0.00 & 0.00 & 0.00 & 0.00 & 0.00 & 0.00 & 0.00 & 0.00 & 0.00 \\
\hline Hillsborough & 0.00 & 0.00 & 0.00 & 0.00 & $1,594.69$ & $1,594.69$ & 0.00 & $1,594.69$ & $1,594.69$ \\
\hline Holmes & 0.00 & 0.00 & 0.00 & 0.00 & 0.00 & 0.00 & 0.00 & 0.00 & 0.00 \\
\hline Indian River & 0.00 & 0.00 & 0.00 & 0.00 & 2.19 & 2.19 & 0.00 & 2.19 & 2.19 \\
\hline Jackson & 0.23 & 0.00 & 0.23 & 40.12 & 0.00 & 40.12 & 40.35 & 0.00 & 40.35 \\
\hline Jefferson & 0.00 & 0.00 & 0.00 & 0.00 & 0.00 & 0.00 & 0.00 & 0.00 & 0.00 \\
\hline Lafayette & 0.00 & 0.00 & 0.00 & 0.00 & 0.00 & 0.00 & 0.00 & 0.00 & 0.00 \\
\hline Lake & 0.23 & 0.00 & 0.23 & 0.00 & 0.00 & 0.00 & 0.23 & 0.00 & 0.23 \\
\hline Nassau & 0.00 & 0.00 & 0.00 & 0.00 & 0.00 & 0.00 & 0.00 & 0.00 & 0.00 \\
\hline Okaloosa & 0.00 & 0.00 & 0.00 & 0.00 & 0.00 & 0.00 & 0.00 & 0.00 & 0.00 \\
\hline Okeechobee & 0.00 & 0.00 & 0.00 & 0.00 & 0.00 & 0.00 & 0.00 & 0.00 & 0.00 \\
\hline Orange & 0.73 & 0.00 & 0.73 & 0.00 & 0.00 & 0.00 & 0.73 & 0.00 & 0.73 \\
\hline Osceola & 0.12 & 0.00 & 0.12 & 0.00 & 0.00 & 0.00 & 0.12 & 0.00 & 0.12 \\
\hline Palm Beach & 1.26 & 0.00 & 1.26 & 0.73 & 493.39 & 494.12 & 1.99 & 493.39 & 495.38 \\
\hline Pasco & 0.43 & 0.00 & 0.43 & 0.00 & $1,775.50$ & $1,775.50$ & 0.43 & $1,775.50$ & $1,775.93$ \\
\hline Pinellas & 0.00 & 0.00 & 0.00 & 0.00 & 488.27 & 488.27 & 0.00 & 488.27 & 488.27 \\
\hline Polk & 5.92 & 0.00 & 5.92 & 7.83 & 0.00 & 7.83 & 13.75 & 0.00 & 13.75 \\
\hline Putnam & 0.45 & 0.00 & 0.45 & 14.98 & 0.00 & 14.98 & 15.43 & 0.00 & 15.43 \\
\hline St. Johns & 0.00 & 0.00 & 0.00 & 0.00 & 0.00 & 0.00 & 0.00 & 0.00 & 0.00 \\
\hline St. Lucie & 0.00 & 1.06 & 1.06 & 0.00 & $1,482.93$ & $1,482.93$ & 0.00 & $1,483.99$ & $1,483.99$ \\
\hline Santa Rosa & 0.55 & 0.00 & 0.55 & 0.00 & 0.00 & 0.00 & 0.55 & 0.00 & 0.55 \\
\hline Sarasota & 0.00 & 0.00 & 0.00 & 0.00 & 0.00 & 0.00 & 0.00 & 0.00 & 0.00 \\
\hline Seminole & 0.00 & 0.00 & 0.00 & 0.00 & 0.00 & 0.00 & 0.00 & 0.00 & 0.00 \\
\hline Sumter & 0.00 & 0.00 & 0.00 & 0.00 & 0.00 & 0.00 & 0.00 & 0.00 & 0.00 \\
\hline Suwannee & 0.10 & 0.00 & 0.10 & 134.59 & 0.00 & 134.59 & 134.69 & 0.00 & 134.69 \\
\hline Taylor & 0.00 & 0.00 & 0.00 & 0.00 & 0.00 & 0.00 & 0.00 & 0.00 & 0.00 \\
\hline Union & 0.00 & 0.00 & 0.00 & 0.00 & 0.00 & 0.00 & 0.00 & 0.00 & 0.00 \\
\hline Volusia & 0.28 & 0.00 & 0.28 & 10.20 & 0.00 & 10.20 & 10.48 & 0.00 & 10.48 \\
\hline Wakulla & 0.00 & 0.00 & 0.00 & 0.23 & 0.00 & 0.23 & 0.23 & 0.00 & 0.23 \\
\hline Walton & 0.00 & 0.00 & 0.00 & 0.00 & 0.00 & 0.00 & 0.00 & 0.00 & 0.00 \\
\hline Washington & 0.00 & 0.00 & 0.00 & 0.00 & 0.00 & 0.00 & 0.00 & 0.00 & 0.00 \\
\hline State totals & 27.83 & 28.52 & 56.35 & 406.19 & $9,396.31$ & $9,802.50$ & 434.02 & $9,424.83$ & $9,858.85$ \\
\hline
\end{tabular}


of these new technologies, water withdrawals generally began to decrease statewide after the 1990s, while the amount of power generated continued to increase.

Between 2000 and 2015, freshwater withdrawals decreased by 34 percent and saline-water withdrawals decreased by 21 percent. Between 2010 and 2015, freshwater withdrawals decreased by 23 percent while saline-water withdrawals increased by 8 percent. However, the total amount of gross power generated statewide increased nearly 19 percent (32,000 GWh) between 2000 and 2015 (Marella, 2004) but remained nearly the same between 2010 and 2015. As a result of more efficient combined-cycle technology, water demand continued to decrease between 2000 and 2015, and this trend of increased power production and decreased water demand statewide is expected to continue (Ron Hix, Florida Power and Light, written commun, 2014; U.S. Energy Information Administration, 2018). Additionally, differences between years could be a consequence of facility downtime caused by plant maintenance or retooling. Prolonged downtime can substantially reduce the annual average water withdrawals at power generation facilities, which is particularly evident when data are only collected every 5 years.

\section{Water Source, Use, and Trends by Water Management District}

The Florida Water Resources Act of 1972 established authority for management of the State's water resources through five WMDs that operate under the general supervision of the FDEP, which was formerly the Florida Department of Natural Resources and subsequently the Florida Department of Environmental Regulation (Fernald and Patton, 1984). The five WMDs (fig. 2), which encompass the entire State,

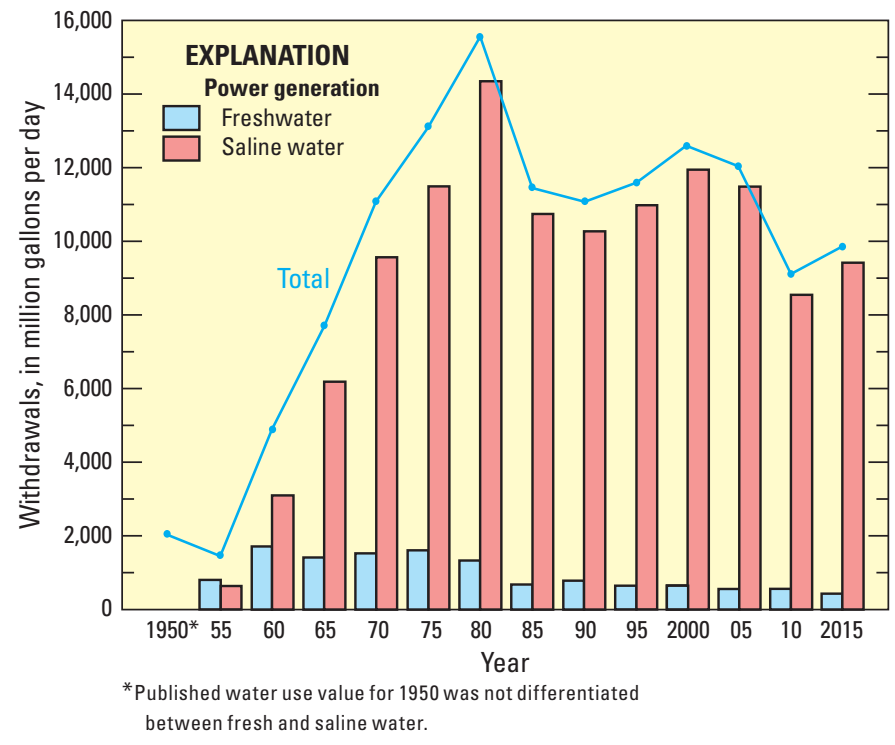

Figure 16. Historical power-generation water withdrawals in Florida by source, 1950-2015. Modified from Marella (2014). vary considerably in population. Of the 19.815 million people who resided in Florida during 2015, nearly 41 percent resided in the SFWMD (8.203 million); 25 percent each resided in the SWFWMD and the SJRWMD (4.997 million and 4.867 million, respectively); 7 percent resided in the NWFWMD (1.418 million); and the remaining 2 percent resided in the SRWMD (0.329 million) (fig. 17). The SFWMD included the largest number of residents served by public-supply water systems (7.743 million) (fig. 17), and the SJRWMD had the largest self-supplied population (0.701 million) in 2015.

The SFWMD accounted for the largest percentage of freshwater withdrawals (49 percent) in 2015 (fig. 18 and table 11), followed by the SJRWMD and SWFWMD (18 percent each), NWFWMD (9 percent), and SRWMD (6 percent). The SFWMD accounted for the largest percentage of freshwater withdrawals for public-supply use (44 percent), agricultural self-supplied use (66 percent), and recreational-landscape irrigation use (66 percent). The SJRWMD accounted for the largest percentage of freshwater withdrawn for commercial-industrial-mining self-supplied use (27 percent), the NWFWMD accounted for the largest percentage of freshwater withdrawals for power-generation use (50 percent), and the SWFWMD accounted for the largest percentage of saline-water withdrawals for power-generation use (54 percent) (table 11). The SWFWMD accounted for the largest percentage of saline-water withdrawals (54 percent), and the SFWMD accounted for the largest percentage of fresh groundwater and surface-water withdrawals (49 percent) in 2015 (fig. 19 and table 11).

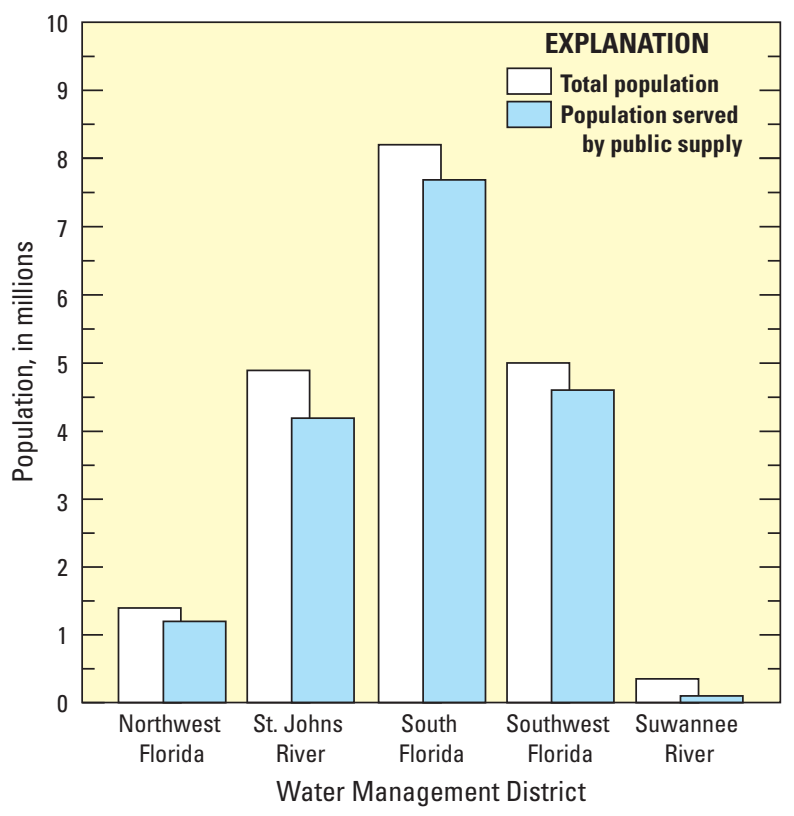

Figure 17. Total population and population served by public supply in Florida by water management district, 2015. Modified from Marella (2014), Ferguson (2016), St. Johns River Water Management District (2016), and Harmon and others (2017). 


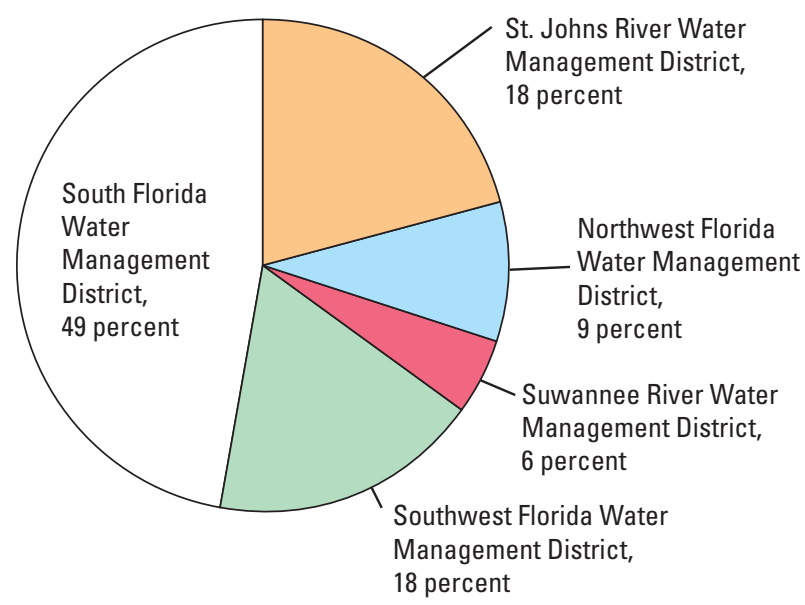

Figure 18. Freshwater withdrawals in Florida by water management district, 2015. Modified from Ferguson (2016), St. Johns River Water Management District (2016), and Harmon and others (2017).

Since water-use data were first compiled by the WMDs in 1975, freshwater withdrawals in the SFWMD, excluding those for power generation, have changed more than in any other WMD (fig. 20). The major categories of use between 1975 and 2015 are illustrated for each WMD in figure 21. For the 5-year intervals during this time period, trends illustrated in figure 21 were evaluated using the Kendall-tau non-parametric test at the 0.05 probability cutoff for significance (Kendall, 1938). Public-supply water use had a significant upward trend for all WMDs, commercial-industrial-mining self-supplied water use had a significant downward trend for all WMDs except SFWMD, and agriculture self-supplied water use had a significant upward trend for SRWMD. Domestic self-supplied water use did not have a significant trend for any WMD. For the SJRWMD and SFWMD, public supply has increased over time but has leveled off more recently, while agricultural self-supplied has decreased over the past 15 years. For the SWFWMD, both agricultural self-supplied and commercial-industrial-mining self-supplied continue to decrease over the past 15 years while public supply has remained about the same. For the NWFWMD, public supply has increased over time but has leveled off over the past 15 years, while commercial-industrial-mining self-supplied has decreased somewhat over time. For the SRWMD, agricultural self-supplied has increased over time while commercial-industrial-mining has slowly decreased over time.

Significant downward trends in public-supply gross per capita water use for the 5-year intervals spanning 1975 to 2015 were indicated for NWFWMD, SJRWMD, and SFWMD, based on the Kendall-tau non-parametric test at the 0.05 probability cutoff. Another noticeable trend within the WMDs is the steady decrease in public-supply gross per capita use between 1995 and 2010 (fig. 22). Increased water conservation efforts, permitting constraints or limits imposed by the WMDs to water suppliers, and the use of alternative water sources, primarily for lawn irrigation, may have impacted these per capita values over this time period. Reclaimed wastewater used for residential lawn irrigation has increased from $95 \mathrm{Mgal} / \mathrm{d}$ in 2000 (Florida Department of Environmental Protection, 2011) to $193 \mathrm{Mgal} / \mathrm{d}$ in 2015 (Florida Department of Environmental Protection, 2016), which helps offset public-supply withdrawals and lower per capita use. In addition, many public-supply customers have drilled small lawn irrigation wells to offset public-supply water for lawn irrigation in many areas of the State. For example, between 1995 and 2015 in Sarasota County alone, nearly 14,000 wells were permitted to be drilled for lawn irrigation (fig. 23).

\section{Water Withdrawal and Use Trends for Florida, 1950-2010}

Statewide water-withdrawal and water-use estimates have been compiled for Florida every 5 years since 1950; however, trends in historical water-use values are sometimes difficult to assess because of differences in data-collection techniques and methods and changing sources of information through the years (Marella, 2004, 2009). Since 1970, statewide water-use data for all withdrawal categories have been collected, tabulated, and published nine times at 5-year intervals by many agencies (the five WMDs, Florida Geological Survey, and the USGS). When water-use data are only compiled at 5-year intervals, any unique circumstance occurring within a single year can substantially affect the values for a 5 -year interval, and therefore, caution should be used when comparing data. For example, water withdrawals for 2000 were very high, primarily because of low rainfall that led to higher irrigation demands for agricultural self-supplied use, recreational-landscape irrigation, and public supply (from residential lawn watering) (fig. 24). The large withdrawals in 2000 resulted in a trend between 1995 and 2000 that, in effect, shows a large increase in water withdrawals. Under average rainfall conditions, water withdrawals might have changed very little between these years. To further illustrate the limitations of 5-year data trends, when data for 5 -year intervals are compared to annual data, such as for public-supply withdrawals (for which estimates of annual statewide totals are available from 1985 to 2012), it is evident that not all of the unusually high or low public-supply withdrawals occurred at 5-year intervals (fig. 25). In addition, statewide totals presented on these 5 -year intervals might reflect a large change caused by downtime at one of the State's powerplants anytime during that specific year. Therefore, trends based solely on 5-year intervals should be viewed with some caution; however, these snapshots of water withdrawal over time do provide a good historical summary and provide some insight into future changes.

Combined freshwater and saline-water withdrawals increased by 12,665 Mgal/d (477 percent) between 1950 and 2015, while the population of Florida increased by 17.050 million ( 615 percent) during this 65 -year period (fig. 26 and table 12). Total freshwater withdrawals decreased 
Table 11. Water withdrawals by category in Florida by water management district, 2015.

[Source, U.S. Geological Survey data release (Marella and Dixon, 2018); Ferguson (2016), St. Johns River Water Management District (2016), and Harmon and others (2017). Values presented in this table may not be identical to those reported or published by the water management districts because of differences in data-collection procedures, methodologies used, or definitions of water categories or use. General locations of the water management districts are shown in figure 2. All values are in million gallons per day]

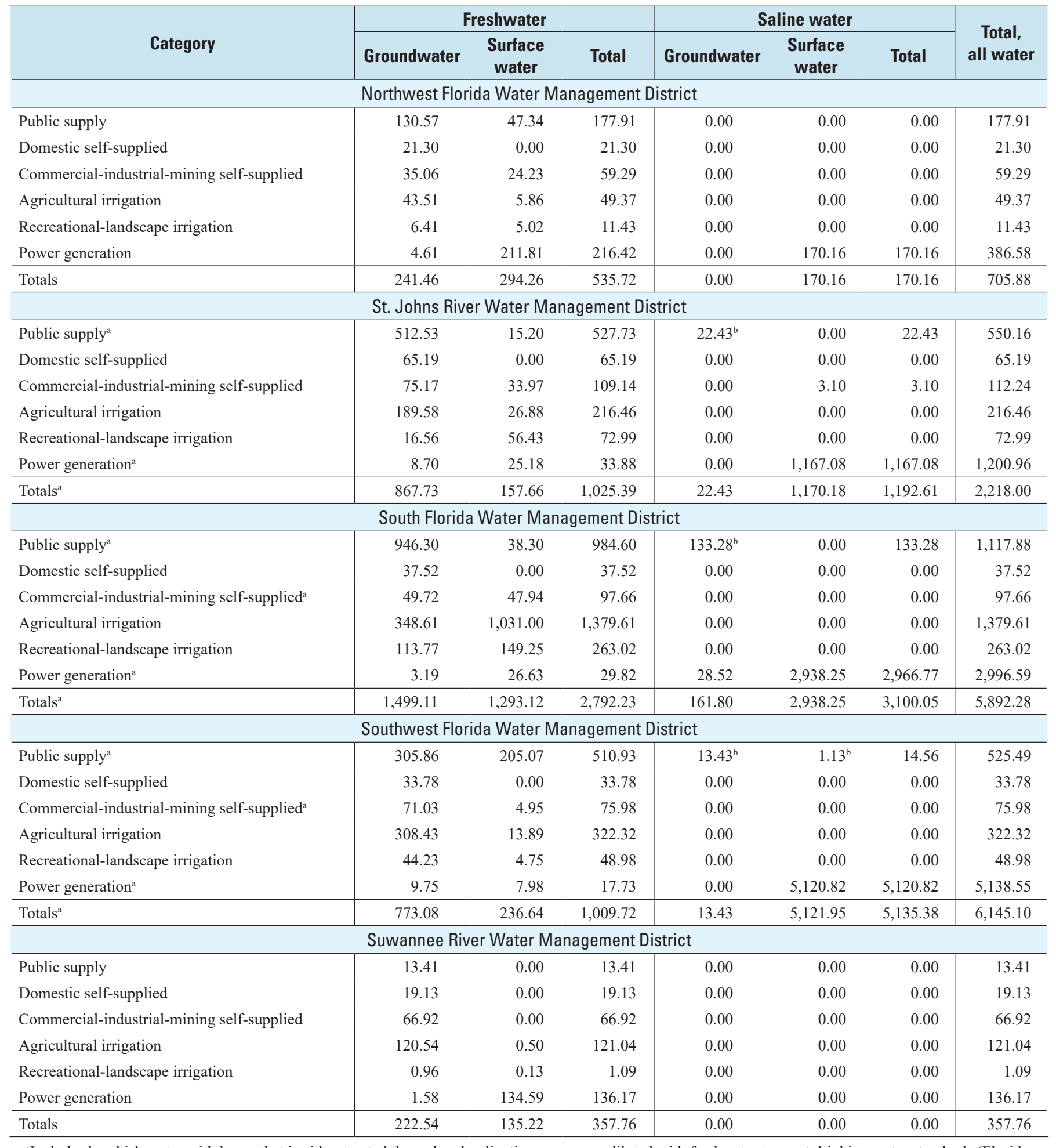

ancludes brackish water withdrawn that is either treated through a desalination process or diluted with freshwater to meet drinking water standards (Florida Department of Environmental Regulation, 1990). For 2015, this water is classified as saline water by the U.S. Geological Survey but is reported as freshwater by the water management districts.

${ }^{b}$ Values shown for these categories or totals differ from those reported or published by the water management districts. 


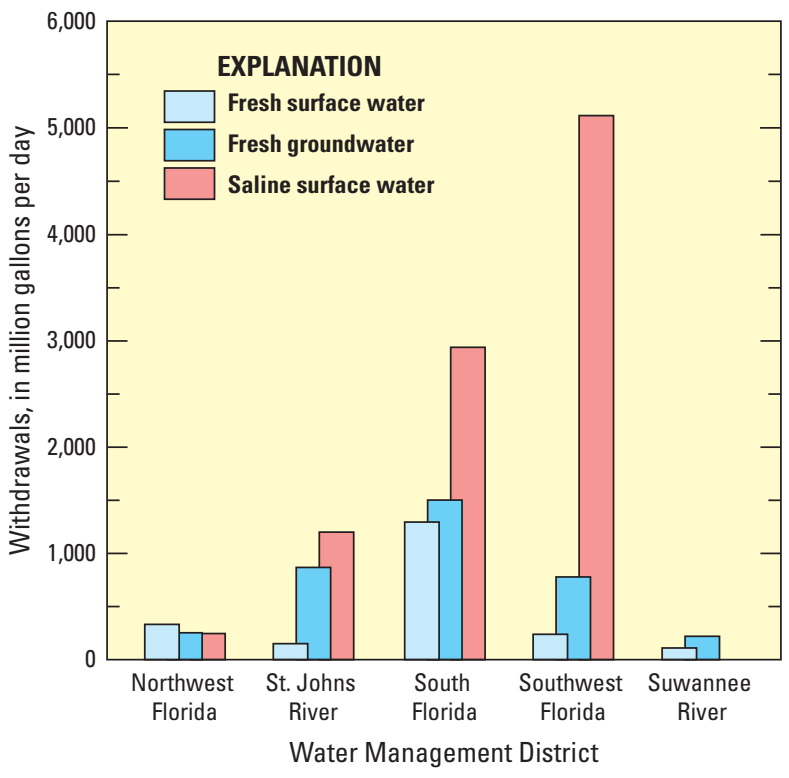

Figure 19. Freshwater and saline-water withdrawals in Florida by water management district, 2015. Modified from Ferguson (2016), St. Johns River Water Management District (2016), and Harmon and others (2017).

by 2,471 Mgal/d (30 percent) between 2000 and 2015, while the population increased by 3.833 million ( 24 percent), and total freshwater withdrawals decreased by $679 \mathrm{Mgal} / \mathrm{d}$ (11 percent) between 2010 and 2015, while the population increased by 1.014 million (5 percent) (fig. 26). Total saline-water withdrawals (ground and surface) decreased by nearly 2,358 Mgal/d (20 percent) between 2000 and 2015 but increased by more than $1,009 \mathrm{Mgal} / \mathrm{d}$ (12 percent) between 2010 and 2015. The 2015 saline groundwater withdrawals include $169 \mathrm{Mgal} / \mathrm{d}$ of public-supply water classified as saline that in previous years would have been classified as freshwater.
Overall, saline-water withdrawals were highest in 1977 (table 12) and 1980 (fig. 26). Between 1985 and 2005, saline-water withdrawals have ranged between 10,400 and $12,000 \mathrm{Mgal} / \mathrm{d}$; however, beginning in 2010, saline-water withdrawals fell below 10,000 Mgal/d (fig. 26). This trend reflects the power industry's movement toward building more efficient facilities or retooling existing facilities that produce more power and use less water relative to those in the past. The shift occurred in the 1980s and early 1990s, and its effects became apparent from 2000 onward. As the gross power generated in Florida increased by 35,000 GWh (21 percent) between 2000 and 2015, the saline-water withdrawals used to produce power decreased by $2,530 \mathrm{Mgal} / \mathrm{d}$ (21 percent). A second saline-water withdrawal trend in Florida is in the public-supply category. Treated, nonpotable water withdrawn for public supply increased from $2.5 \mathrm{Mgal} / \mathrm{d}$ in 1980 to $170 \mathrm{Mgal} / \mathrm{d}$ in 2015 (table 12). This water is treated to meet drinking-water standards and is considered saline but was reported as fresh (classified as brackish) in previous years (1970-2012), as listed in table 13.

Freshwater withdrawals remained relatively constant from 1975 to 1985, increased by 1990, peaked in 2000, and have decreased steadily thereafter (fig. 26 and table 12). Total freshwater withdrawals for 2000 were $1,419 \mathrm{Mgal} / \mathrm{d}$ (21 percent) higher than those in 1975, whereas values for 2015 were $2,471 \mathrm{Mgal} / \mathrm{d}$ (30 percent) lower than those in 2000. In 1975, agricultural self-supplied accounted for 43 percent of the total freshwater withdrawals, followed by power generation (24 percent) and public supply (17 percent). By 2000, agricultural self-supplied represented 48 percent of the total freshwater withdrawals, followed by public supply at 30 percent, and by 2015, agricultural self-supplied represented 37 percent, which public supply surpassed at 39 percent (fig. 4). Over the 40-year period between 1975 and 2015, increases in freshwater withdrawals caused by large gains in population and the expansion of irrigated acreage were offset by decreases in water used for power generation

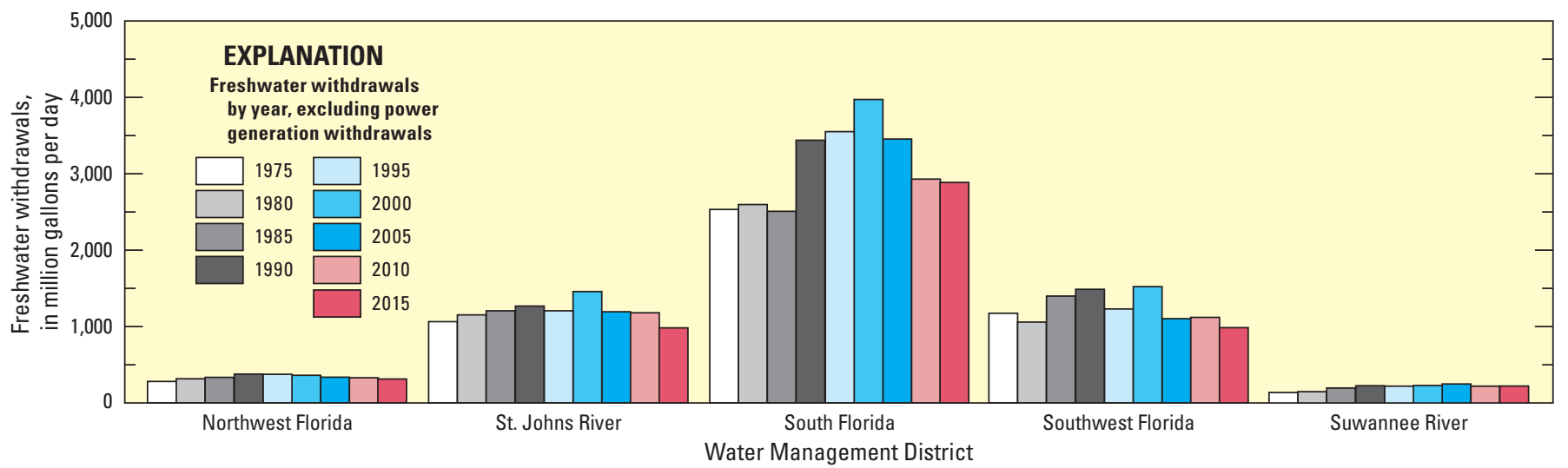

Figure 20. Historical freshwater withdrawals (excluding power generation) in Florida by water management district, 1975-2015. Modified from Marella (2014), Ferguson (2016), St. Johns River Water Management District (2016), and Harmon and others (2017). 

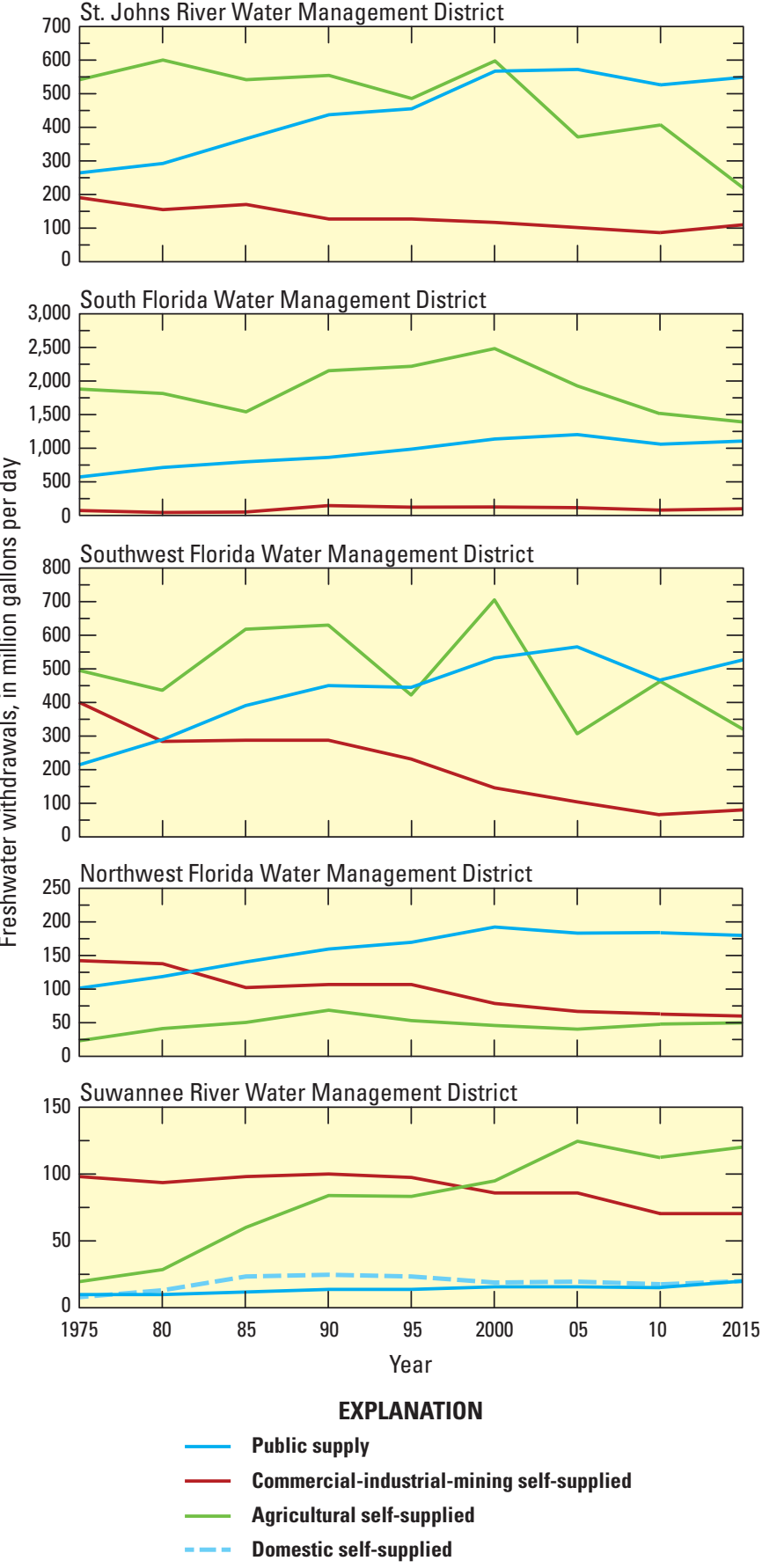

Figure 21. Historical freshwater withdrawals by water-use category in Florida by water management district, 1975-2015. Modified from Marella (2014), Ferguson (2016), St. Johns River Water Management District (2016), and Harmon and others (2017). Trends for all categories are only presented for the Suwannee River Water Management District. and commercial-industrial-mining withdrawals. Since 2000, however, irrigated acreage has decreased statewide because of crop diseases, storm damage, and urbanization. This decrease and the large gains in water conservation measures in the farming industry have led to agricultural self-supplied withdrawals in Florida being lower than public-supply withdrawals for the first time since water-use data were collected (fig. 24).

Fresh groundwater withdrawals increased relatively steadily between 1950 and 2000 and declined thereafter (fig. 27). This long-term overall trend in groundwater withdrawals is a result of many factors, the most prominent being the availability of large quantities of high-quality freshwater underlying most areas of the State, coupled with the ability to pump large volumes of water economically from deep wells (Vecchioli and Foose, 1985). In addition, increases in demand posed by population growth, tourism, and crop irrigation have increased the importance of groundwater use during the past 60 years. Groundwater has been the primary source of freshwater in Florida since 1980 (fig. 27), supplying about 60 percent of the total freshwater withdrawals between 1980 and 2015.

Fresh surface-water withdrawals increased substantially between 1950 and 1975, peaking in 1965; more recently, they declined between 2000 and 2015 (fig. 27 and table 12). The early increasing trend in fresh surface-water withdrawals was caused by an increase in power generation during the 1950s and 1960s when many facilities were built. In addition, the draining of land for crop production around Lake Okeechobee through a series of canals, levees, and pump stations built between the 1950s and 1960s made surface water available to irrigate thousands of acres of vegetables and sugarcane (Renken and others, 2005). Overall, demands for both fresh groundwater and surface-water withdrawals have declined because of changes in the State's economy, water conservation and management efforts, and the use of alternative water sources (primarily reclaimed wastewater).

For the 5-year intervals within the 1975-2015 time period (fig. 28), public-supply water use had a significant upward trend, and commercial-industrial-mining self-supplied, power generation and public-supply gross per capita water uses had significant downward trends. Agriculture selfsupplied water uses did not have a significant trend. Data for recreation water use were available for 1985-2015 and no significant trend was indicated. Significance of trends was based on the Kendall-tau non-parametric test at the 0.05 probability cutoff for significance. Freshwater withdrawals for domestic self-supplied use, agricultural self-supplied use, commercial-industrial-mining self-supplied use, and power generation use all have been decreased since 2000, whereas water withdrawals for public-supply use (fresh and saline) and recreational-landscape irrigation use have remained about the same during this same period (fig. 28 and table 13). The use of reclaimed wastewater increased from $575 \mathrm{Mgal} / \mathrm{d}$ in 2000 to nearly $738 \mathrm{Mgal} / \mathrm{d}$ in 2015 (Florida Department 


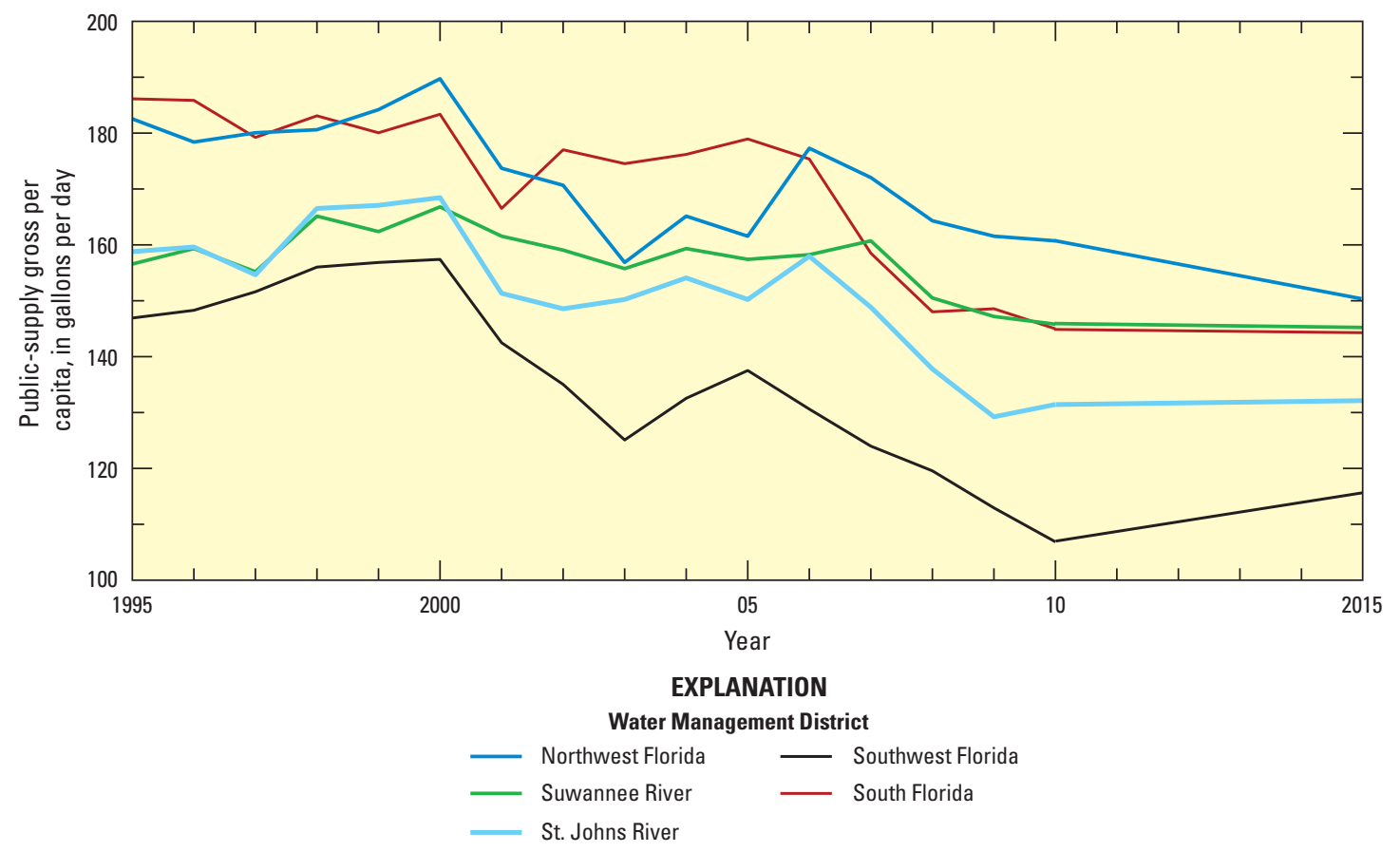

Figure 22. Historical public-supply gross per capita water use in Florida by water management district, 1975-2015. Modified from Marella (2014), Ferguson (2016), St. Johns River Water Management District (2016), and Harmon and others (2017).

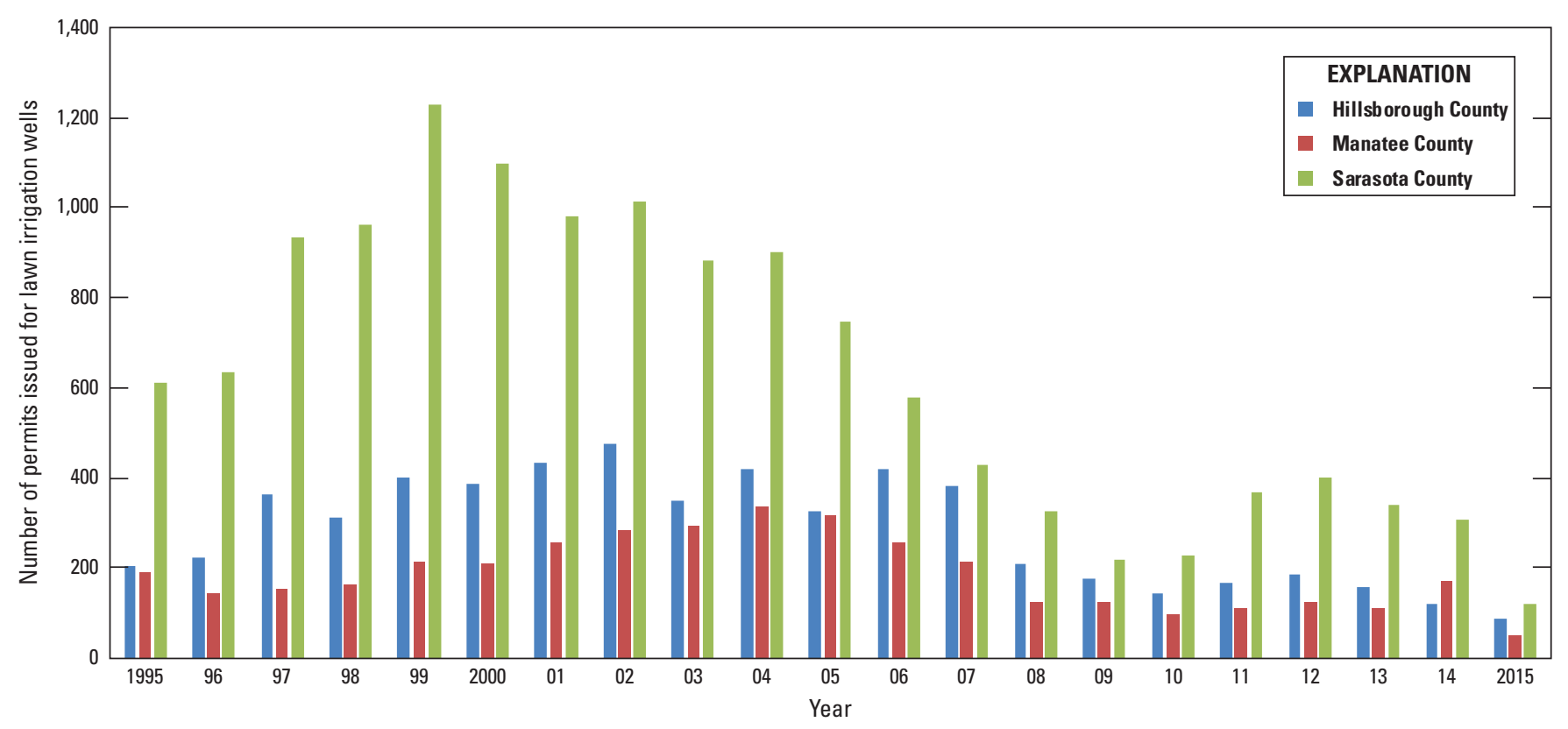

Figure 23. Number of permits issued by the county health departments for private lawn irrigation wells, 1995-2015. 


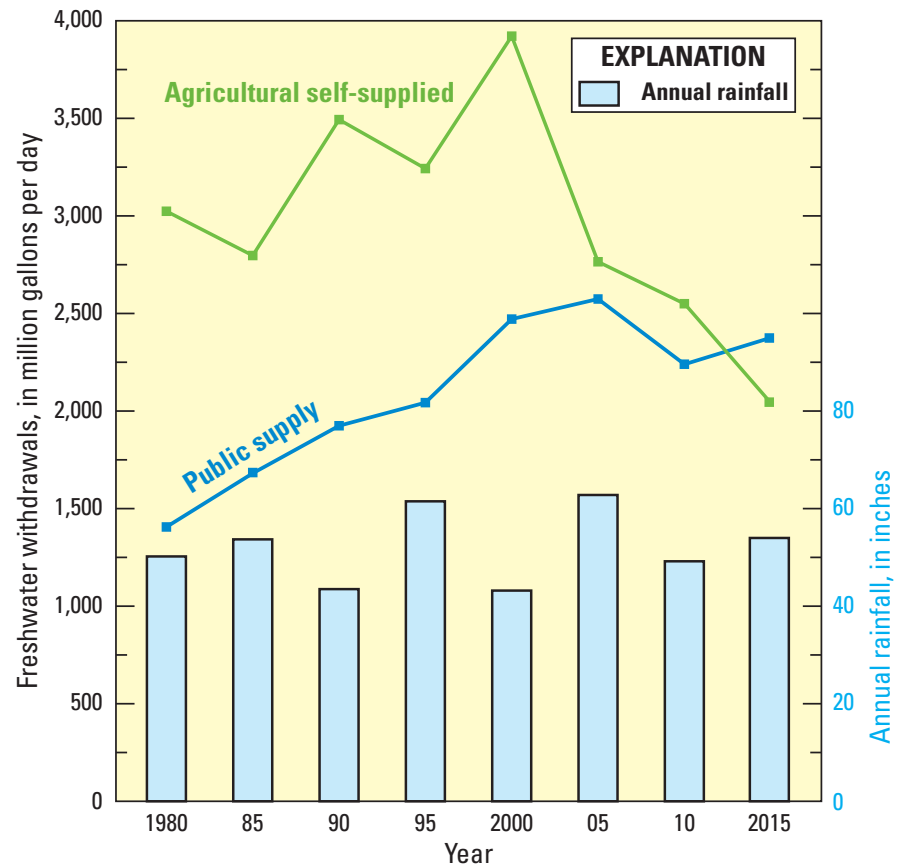

Figure 24. Freshwater withdrawals for agricultural self-supplied and public-supply use with statewide average annual rainfall in Florida, 1980-2015. Modified from Marella (2014) and Florida State University (2017).

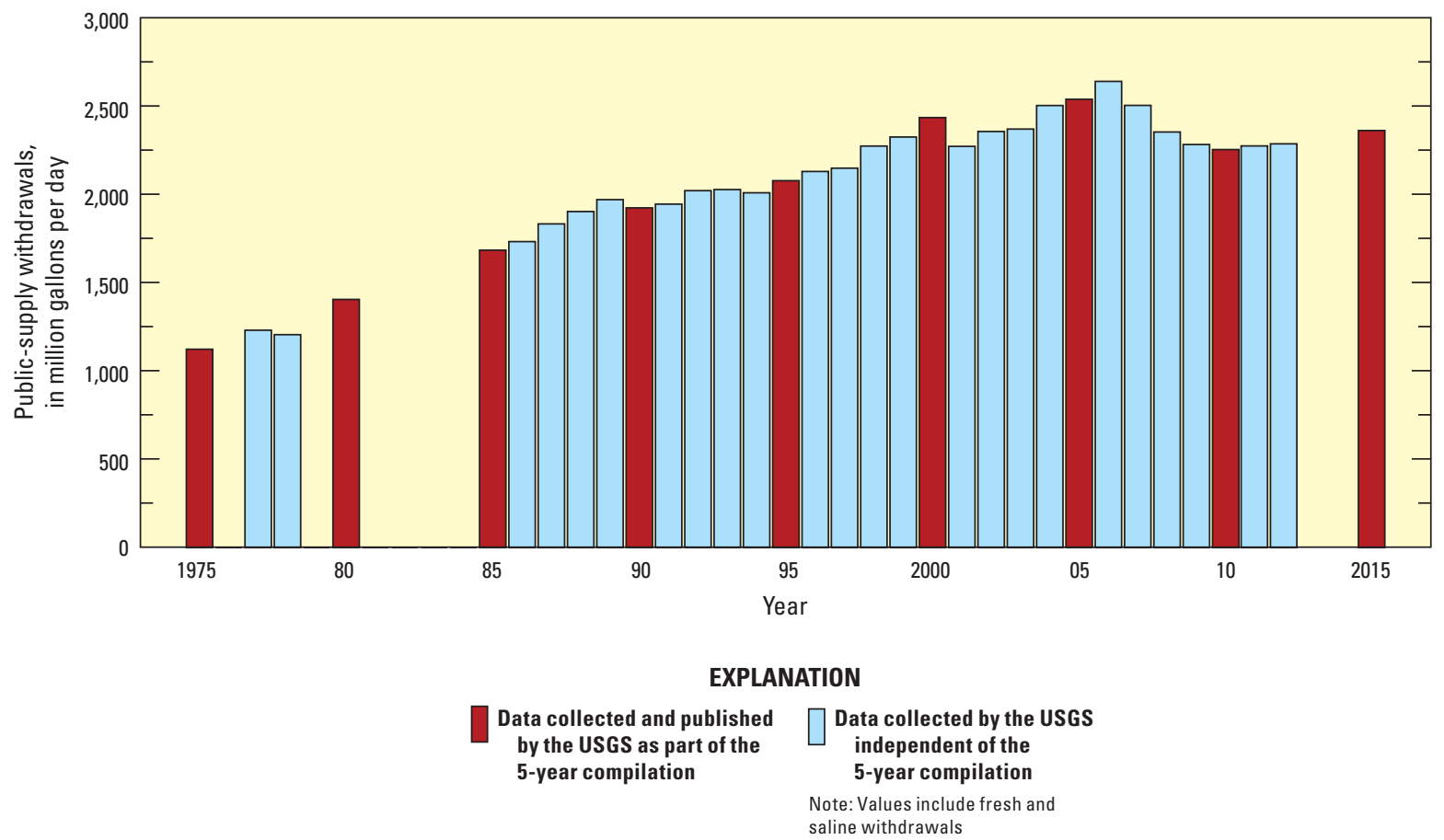

Figure 25. Historical public-supply withdrawals in Florida, 1975-2015. Modified from Marella $(2014,2015)$. 


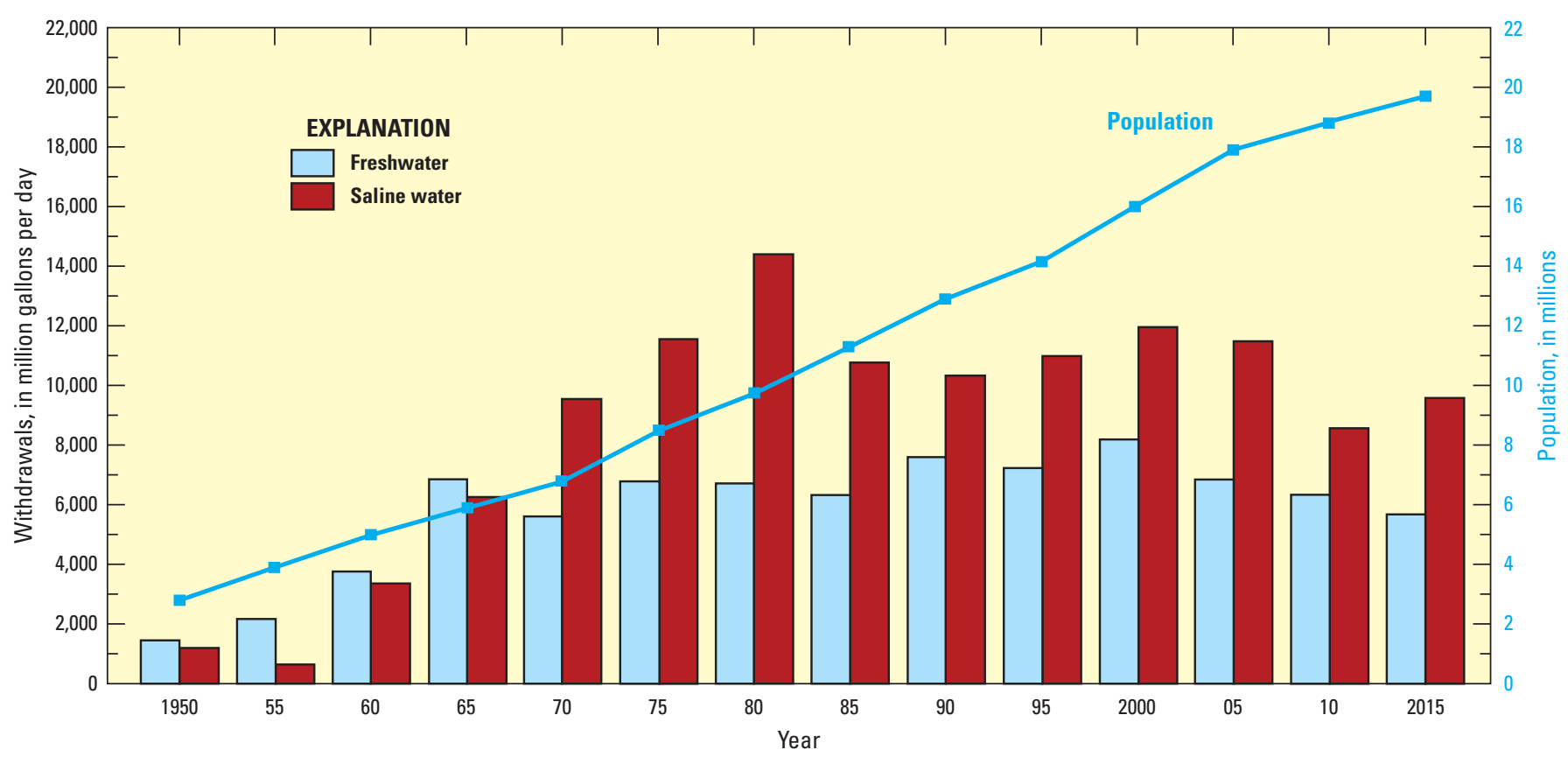

Figure 26. Historical total population, freshwater, and saline-water withdrawals in Florida, 1950-2015. Modified from Dietrich (1978), Marella (2014), and University of Florida (2015a).

of Environmental Protection, 2006, 2016). Nearly 83 percent of the reclaimed wastewater flow in 2015 was used to reduce potable-quality water withdrawals for urban irrigation (such as for golf courses, parks, schools, and residential lawns), agricultural irrigation, and industrial use; the remaining reclaimed wastewater was returned to the hydrologic system as aquifer recharge (13 percent) and through wetland discharge (4 percent) (Florida Department of Environmental Protection, 2016). Increases in the use and value of reclaimed wastewater are expected to continue statewide. Additionally, the use of private lawn irrigation wells is widespread throughout Florida, and it is believed that the number of wells constructed for this purpose increased substantially from 2000 to 2015 . According to a water-well industry report (Gale Group, 2013), more than 795,000 wells were drilled in Florida between 2002 and 2011, with a large number of these intended for individual uses such as domestic drinking water or landscape irrigation. Other alternative sources of water include aquifer storage and recovery systems, whereby water suppliers inject and store excess surface water that becomes available during the wet season into a deep aquifer and then recover it during the dry season, if needed, to help offset peak demand (Reese, 2006).

Many factors that affect water demand in Florida are detailed in this report (economic, regulatory, population, and weather, among others); many other factors not mentioned (socioeconomic factors, international trade, commodity and fuel prices, and climate change, among others) may also affect water demand within a given period or geographic area. Because it is difficult to determine or measure the direct effect of any single factor, it is assumed that these factors have a cumulative effect on current and historical water use in Florida and that their influence will continue to vary from year to year.

\section{Summary}

In 2015, the total amount of water withdrawn in Florida was estimated to be 15,319 million gallons per day (Mgal/d). Saline water accounted for $9,598 \mathrm{Mgal} / \mathrm{d}$ (63 percent) and freshwater accounted for 5,721 Mgal/d (37 percent) of the total. Groundwater accounted for 3,604 Mgal/d (63 percent) of freshwater withdrawals, and surface water accounted for the remaining 2,117 Mgal/d (37 percent). Surface-water sources accounted for 9,401 Mgal/d (98 percent) of the saline-water withdrawals, and groundwater sources accounted for the remaining $198 \mathrm{Mgal} / \mathrm{d}$ ( 2 percent). In addition to the water withdrawn for use statewide, $738 \mathrm{Mgal} / \mathrm{d}$ of reclaimed wastewater was also used in Florida during 2015. Freshwater withdrawals were greatest in Palm Beach County $(820 \mathrm{Mgal} / \mathrm{d})$ in southeastern Florida, and saline-water withdrawals were greatest in Pasco County (1,776 Mgal/d) in west-central Florida.

Groundwater provided drinking water (public supplied and self-supplied) for 18.324 million people (92 percent of Florida's population), and fresh surface water provided drinking water for 1.491 million people ( 8 percent). Public-supply water withdrawals totaled 2,372 Mgal/d, of which domestic use was $1,503 \mathrm{Mgal} / \mathrm{d}$. The statewide public-supply gross per capita use for 2015 was 134 gallons per day (gal/d), whereas the statewide public-supply domestic per capita use was $85 \mathrm{gal} / \mathrm{d}$. The majority of groundwater withdrawals (almost 62 percent) in 2015 were from the Floridan aquifer system, which is used throughout most of the State. The majority of fresh surface-water withdrawals (52 percent) occurred in the Southern Florida Subregion, a hydrologic unit that includes Lake Okeechobee and canals in the Everglades Agricultural Area of Palm Beach, Hendry, Martin, and Glades Counties. 
Table 12. Historical population and water withdrawals in Florida by water source in Florida, 1950-2015.

[Source: U.S. Geological Survey, Caribbean-Florida Water Science Center - Orlando; Marella (1988, 2009, 2015), Florida Department of Environmental Regulation (1990), University of Florida (2015a), Florida Department of Environmental Protection (2016). Water values in million gallons per day. N/A, data not available]

\begin{tabular}{|c|c|c|c|c|c|c|c|c|c|c|c|}
\hline \multirow{3}{*}{ Year } & \multirow{2}{*}{\multicolumn{2}{|c|}{$\begin{array}{c}\text { Population } \\
\text { (millions) }\end{array}$}} & \multicolumn{7}{|c|}{ Water withdrawals, in million gallons per day } & \multicolumn{2}{|c|}{ Treated } \\
\hline & & & \multicolumn{3}{|c|}{ Freshwater } & \multicolumn{3}{|c|}{ Saline water ${ }^{\mathrm{a}}$} & \multirow{2}{*}{$\begin{array}{c}\text { Total all } \\
\text { water }\end{array}$} & \multirow{2}{*}{$\begin{array}{c}\text { Nonpotable } \\
\text { water }^{b}\end{array}$} & \multirow{2}{*}{$\begin{array}{c}\text { Reclaimed } \\
\text { water }^{\mathrm{C}}\end{array}$} \\
\hline & Total & $\begin{array}{l}\text { Public } \\
\text { supply }\end{array}$ & Ground & Surface & Total & Ground & Surface & Total & & & \\
\hline 1950 & 2.77 & 1.66 & 614.0 & 840.0 & $1,454.0$ & $\mathrm{~N} / \mathrm{A}$ & $\mathrm{N} / \mathrm{A}$ & $1,200.0$ & $2,654.0$ & $\mathrm{~N} / \mathrm{A}$ & $\mathrm{N} / \mathrm{A}$ \\
\hline 1955 & 3.86 & 2.30 & $1,017.0$ & $1,150.0$ & $2,167.0$ & N/A & N/A & 645.0 & $2,812.0$ & N/A & N/A \\
\hline 1960 & 4.95 & 3.37 & $1,560.0$ & $2,200.0$ & $3,760.0$ & N/A & N/A & $3,360.0$ & $7,120.0$ & N/A & N/A \\
\hline 1970 & 6.79 & 5.42 & $2,786.8$ & $2,825.5$ & $5,612.3$ & 137.0 & $9,385.6$ & $9,552.6$ & $15,273.5$ & 1.6 & N/A \\
\hline 1975 & 8.48 & 6.81 & $3,214.6$ & $3,558.2$ & $6,772.7$ & 95.3 & $11,406.7$ & $11,502.0$ & $18,416.5$ & 1.7 & N/A \\
\hline 1977 & 8.72 & 6.99 & $3,506.4$ & $3,144.5$ & $6,650.9$ & 107.6 & $14,704.1$ & $14,811.7$ & $21,462.6$ & 1.2 & N/A \\
\hline 1980 & 9.75 & 7.79 & $3,677.2$ & $3,024.0$ & $6,701.2$ & 121.2 & $13,776.0$ & $13,897.0$ & $20,598.2$ & 2.5 & N/A \\
\hline 2000 & 15.98 & 14.03 & $5,078.7$ & $3,113.1$ & $8,191.8$ & 3.8 & $11,952.0$ & $11,955.8$ & $20,147.6$ & 95.3 & 575.0 \\
\hline 2005 & 17.92 & 16.13 & $4,247.3$ & $2,625.8$ & $6,873.1$ & 3.3 & $11,482.3$ & $11,485.6$ & $18,358.7$ & 141.7 & 659.7 \\
\hline 2010 & 18.80 & 16.89 & $4,166.5$ & $2,232.8$ & $6,399.3$ & 6.5 & $8,582.5$ & $8,589.0$ & $14,988.3$ & 164.6 & 658.5 \\
\hline 2012 & 19.07 & 16.82 & $4,166.8$ & $2,215.7$ & $6,382.5$ & 6.4 & $7,848.4$ & $7,854.8$ & $14,237.3$ & 146.0 & 725.0 \\
\hline 2015 & 19.82 & 17.71 & $3,603.9$ & $2,116.9$ & $5,720.8$ & 197.7 & $9,400.5$ & $9,597.8$ & $15,318.6$ & 170.3 & 738.2 \\
\hline
\end{tabular}

a Saline water withdrawal totals for 1950, 1955, 1960, and 1965 did not differentiate between ground or surface water.

bNonpotable withdrawals include ground and surface water treated through desalination or diluted with fresher water to meet secondary drinking water standards for public-supply use (Florida Department of Environmental Regulation, 1990). Beginning in 2015, this nonpotable (brackish) water was designated as saline water by the U.S. Geological Survey but was reported as freshwater by the water management districts.

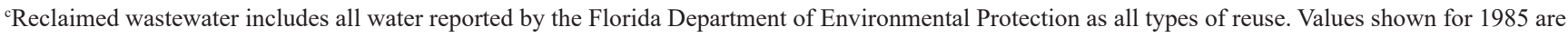
reported for 1986, and those shown for 1995 are reported for 1996.

Freshwater withdrawals were categorized as public-supplied or self-supplied. Public suppliers deliver water for commercial and industrial use, domestic use, public uses (and losses), power generation, and other uses. Self-supplied withdrawals were further categorized as agricultural, commercial-industrial-mining, recreational-landscape irrigation, domestic (private household use), and power generation. Overall, public supply accounted for 39 percent of the total freshwater withdrawals (ground and surface) and 53 percent of groundwater withdrawals, followed by agricultural self-supplied uses, which accounted for 37 percent of the total freshwater withdrawals and 28 percent of groundwater withdrawals. Other self-supplied groundwater withdrawals include commercial-industrial-mining self-supplied (8 percent), recreational-landscape irrigation and domestic self-supplied (5 percent each), and power generation (less than 1 percent). Agricultural self-supplied withdrawals accounted for 51 percent of fresh surface-water withdrawals, followed by power generation (19 percent), public supply (15 percent), recreational-landscape irrigation (10 percent), and commercial-industrial-mining self-supplied (5 percent).
Of the 19.815 million people who resided in Florida during 2015, 8.203 million people (41 percent) resided in the South Florida Water Management District, 4.997 million people (25 percent) resided in the Southwest Florida Water Management District, 4.867 million people (25 percent) resided in St. Johns River Water Management District, 1.418 million people (7 percent) resided in the Northwest Florida Water Management District, and 0.329 million people ( 2 percent) resided in the Suwannee River Water Management District. The largest percentage of freshwater withdrawals was from the South Florida Water Management District (49 percent), followed by the St. Johns River Water Management District and Southwest Florida Water Management District (18 percent each), Northwest Florida Water Management District (9 percent), and Suwannee River Water Management District (6 percent).

Between 1950 and 2015, the population of Florida increased by 17.045 million (615 percent), and the total water withdrawals (fresh and saline) increased by $12,665 \mathrm{Mgal} / \mathrm{d}$ (477 percent). Recently, total freshwater withdrawals decreased by more than 2,471 Mgal/d 


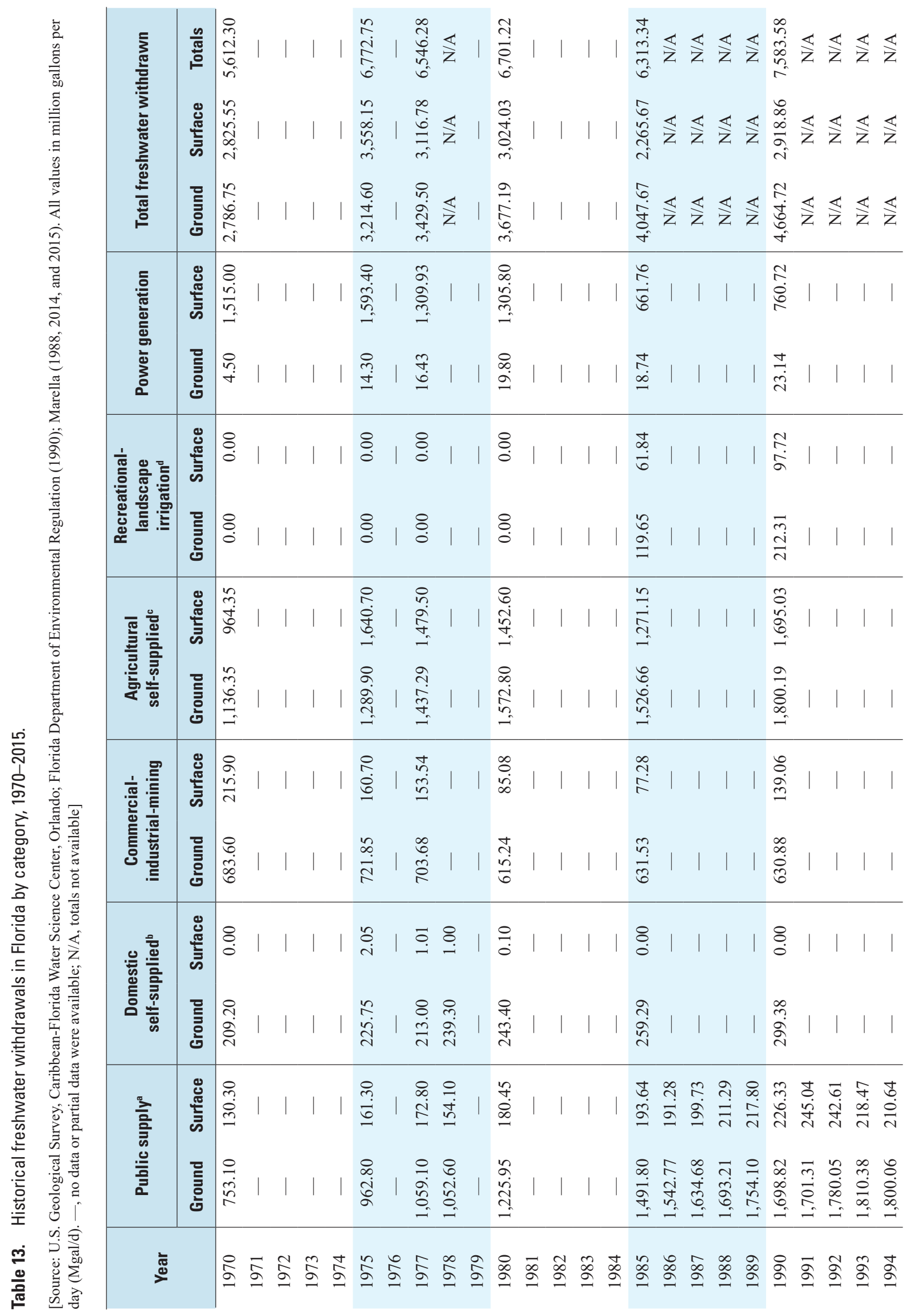




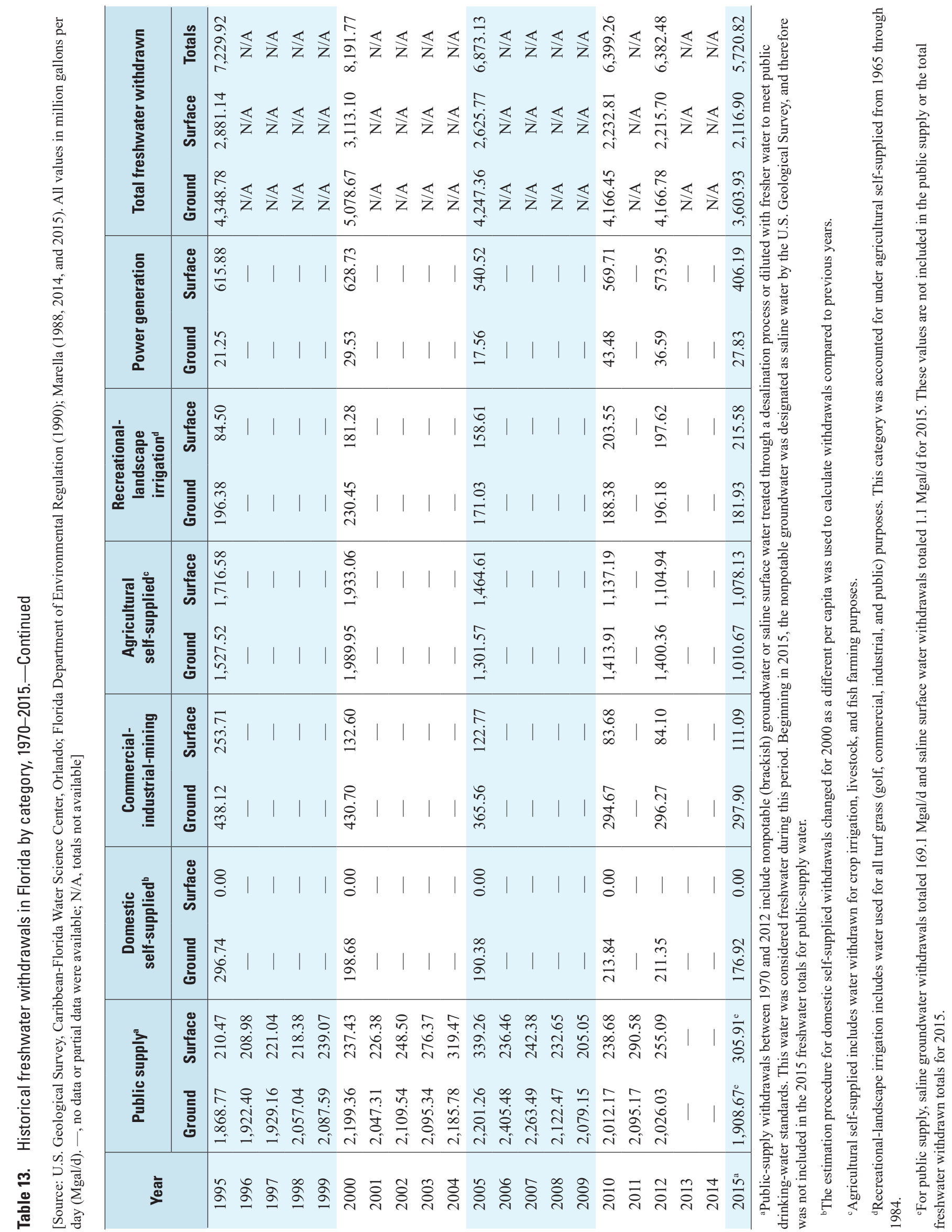




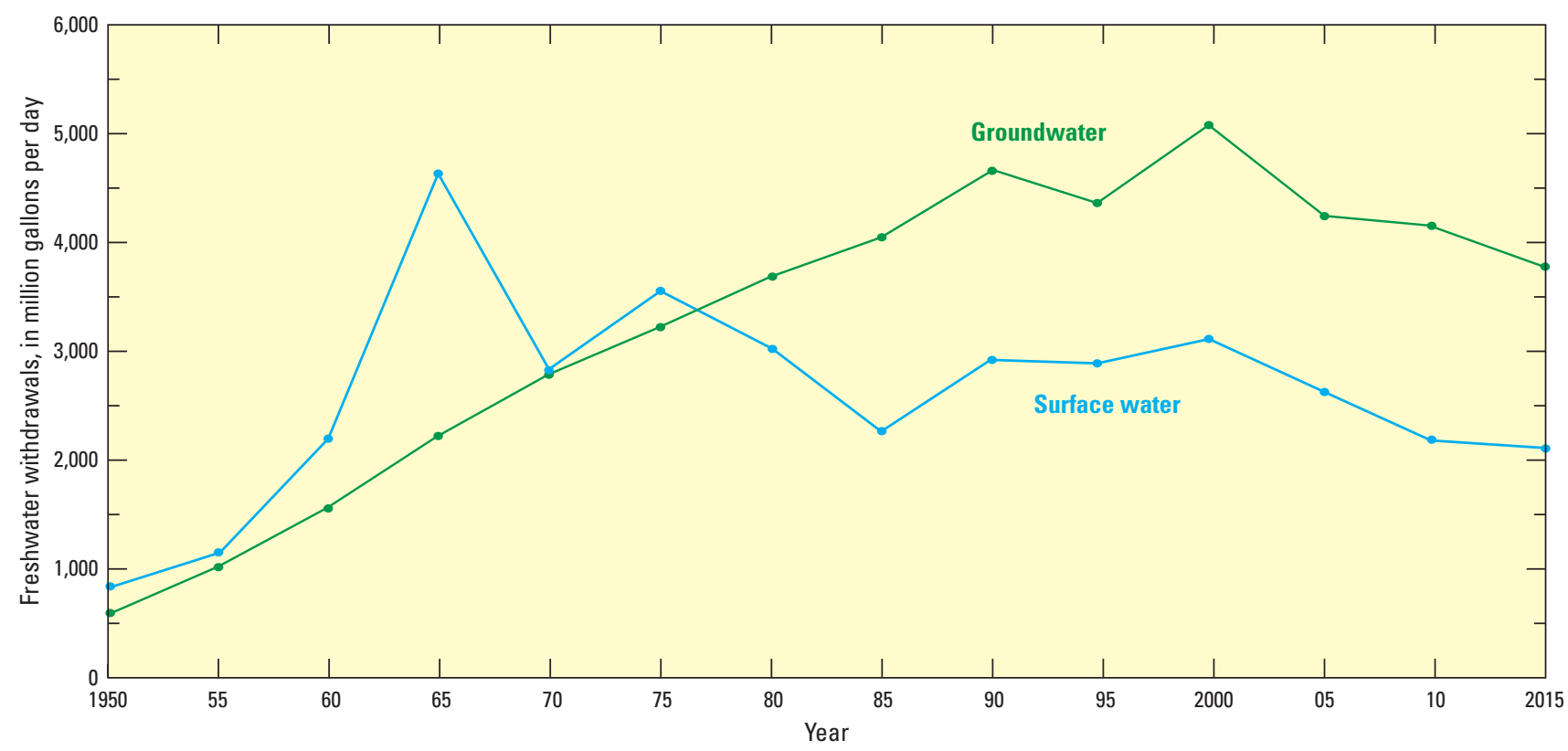

Figure 27. Historical freshwater withdrawals in Florida by source, 1950-2015. Modified from Marella (2014).

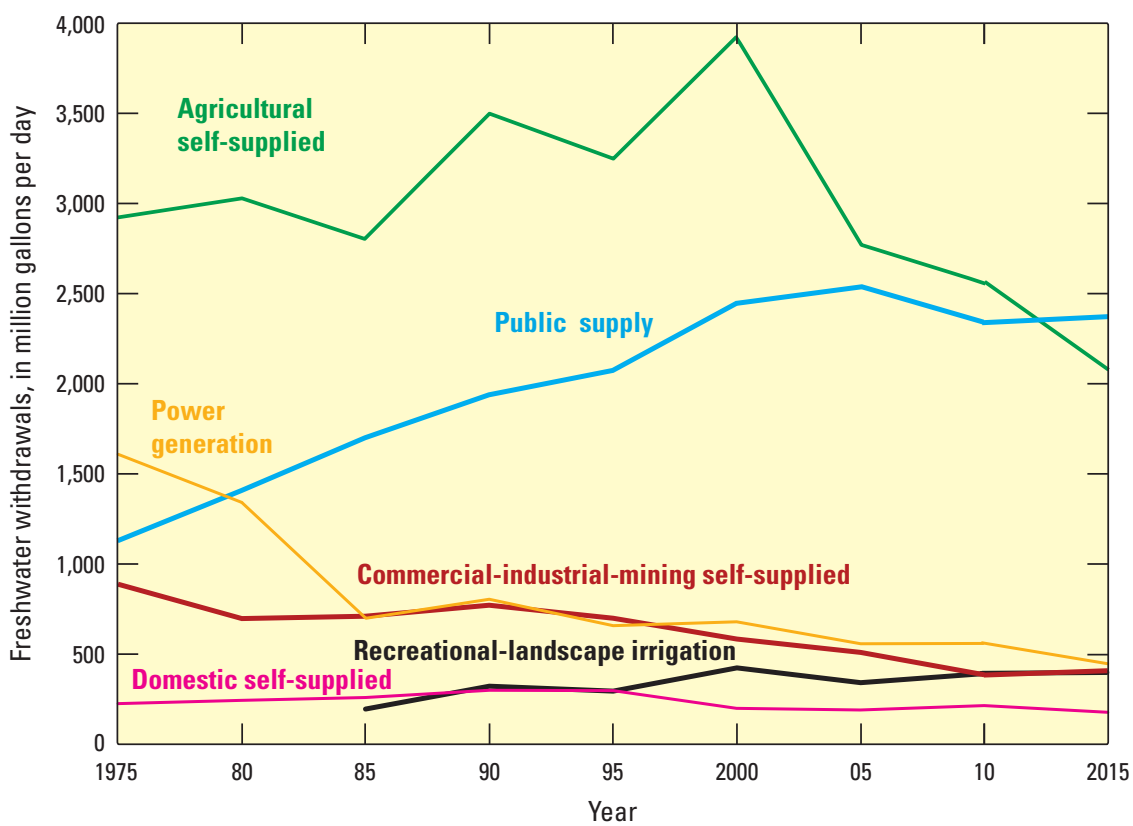

Figure 28. Historical freshwater withdrawals in Florida by selected water-use category, 1975-2015. Modified from Marella (2014). 
(30 percent) between 2000 and 2015, while the population increased by 3.833 million ( 24 percent), and total freshwater withdrawals decreased by more than $531 \mathrm{Mgal} / \mathrm{d}$ (8 percent) between 2010 and 2015, while the population increased by 1.040 million ( 5 percent).

In 1975, agricultural water withdrawals accounted for 43 percent of the total freshwater withdrawals, followed by power generation ( 24 percent) and public supply (17 percent). By 2000, agricultural withdrawals increased to 48 percent of the total freshwater withdrawals, followed by public supply (30 percent). For 2015, agricultural self-supplied decreased to 37 percent of the total freshwater withdrawals and was surpassed by public supply at 39 percent. Over the 40-year period between 1975 and 2015, increases in freshwater withdrawals caused by large gains in population and the expansion of irrigated acreage were offset by decreases in water used for power generation and commercial-industrial-mining withdrawals. Since 2000, however, irrigated acreage has decreased statewide because of crop disease, storm damage, and urbanization. This decline, coupled with large gains in water conservation measures in the farming industry, has led to agricultural withdrawals in Florida being less than public-supply withdrawals for the first time since water-use data were first reported in 1965 .

The use of alternative water sources, such as reclaimed wastewater, has helped lower demands for potable water in several areas of the State, and it is estimated that the statewide reuse per capita for 2015 was 37 gallons per day. The use of reclaimed wastewater in 2015 for residential irrigation and public access uses totaled $324 \mathrm{Mgal} / \mathrm{d}$ in 2015, which helped offset potable water withdrawals. In addition, the availability of groundwater and surface water throughout Florida provides many homeowners and commercial properties within public-supply service areas the opportunity to drill a private well or tap a local canal or lake to irrigate lawns and landscaping.

The use of highly mineralized groundwater (referred to as nonpotable or brackish water) and saline surface water for public supply increased from $2 \mathrm{Mgal} / \mathrm{d}$ in 1970 to nearly $170 \mathrm{Mgal} / \mathrm{d}$ in 2015 . Nearly all (169 Mgal/d) of this treated water was from saline groundwater and the remaining $1 \mathrm{Mgal} / \mathrm{d}$ was from saline surface water. The nonpotable water is either treated using demineralization or desalination techniques (mostly desalination) or is diluted with freshwater to meet Florida Department of Environmental Protection drinking-water standards for potable water. In 2015, these processes were used to obtain potable water for public supply in 15 counties, mostly along the east and west coasts of the Florida peninsula (Brevard, Broward, Charlotte, Collier, Hendry, Hillsborough, Indian River, Lee, Martin, Miami-Dade, Okeechobee, Palm Beach, St. Johns, St. Lucie, and Sarasota). Nonpotable groundwater withdrawals presented in this report are accounted for as saline, as classified by the U.S. Geological Survey Water Availability and Use Science Program.

\section{References Cited}

American Water Works Association, 1992, Water industry data base-Utility profiles: Denver, Colo., American Water Works Association, $80 \mathrm{p}$.

Balmoral Group, 2011, Florida Statewide Agricultural Irrigation Demand (FSAID), Final Report: Winter Park, Fla., The Balmoral Group, LLC, 77 p.

Balmoral Group, 2016, Florida statewide agricultural irrigation demand (FSAID) - Agricultural water demands, 2015-2040, version V: Winter Park, Fla., The Balmoral Group, LLC, 33 p.

Bradley, M.W., 2017, Guidelines for preparation of State water-use estimates for 2015: U.S. Geological Survey Open-File Report 2017-1029, 54 p. [Also available at https://doi.org/10.3133/ofr20171029.]

Bucca, J., and Marella, R.L., 1992, An improved method for determining the nonresidential water use component of total public water supply estimates, in Jones, M.E., and Laenen, Antonius, eds., Interdisciplinary approaches in hydrology and hydrogeology: American Institute of Hydrology, p. 511-523.

Buros, O.K., 1989, Desalting practices in the United States: American Water Works Association Journal, v. 81, no. 11, p. 38-42. [Also available at https://doi.org/10.1002/j.1551-8833.1989.tb03304.x.]

Campbell, K.M., 1986, The industrial minerals of Florida: Tallahassee, Fla., Florida Bureau of Geology Information Circular 102, 94 p.

Coastal, 2006, Jacksonville used to smell really, really bad: The Coastal, January 29, 2019, accessed July 24, 2019, at https://thecoastal.com/flashback/jacksonville-used-to-smellreally-really-bad/.

Davis, W.Y., Rodrigo, D.M., Opitz, E.M., and others, 1988, IWR-Main water use forecasting system, version 5.1User's manual and system description: Fort Belvoir, Va., U.S. Army Corps of Engineers, Institute for Water Resources, IWR-Main Report 88-R-6, 273 p.

Diehl, T.H., and Harris, M.A., 2014, Withdrawal and consumption of water by thermoelectric power plants in the United States, 2010: U.S. Geological Survey Scientific Investigations Report 2014-5184, 28 p. [Also available at https://dx.doi.org/10.3133/sir20145184.]

Diehl, T.H., Harris, M.A., Murphy, J.C., Hutson, S.S., and Ladd, D.E., 2013, Methods for estimating water consumption for thermoelectric power plants in the United States: U.S. Geological Survey, Scientific Investigations Report 2013-5188, 78 p. [Also available at https://doi.org/10.3133/sir20135188.] 
Dieter, C.A., Maupin, M.A., Caldwell, R.R., Harris, M.A., Ivahnenko, T.I., Lovelace, J.K., Barber, N.L., and Linsey, K.S., 2018a, Estimated use of water in the United States in 2015: U.S. Geological Survey Circular 1441, 65 p. [Also available at https://doi.org/10.3133/cir1441.]

Dieter, C.A., Linsey, K.S., Caldwell, R.R., Harris, M.A., Ivahnenko, T.I., Lovelace, J.K., Maupin, M.A., and Barber, N.L., 2018b, Estimated use of water in the United States county-level data for 2015 (ver. 2.0, June 2018): U.S. Geological Survey data release, https://doi.org/10.5066/ F7TB15V5.

Dietrich, T.S., 1978, The urbanization of Florida's population-An historical perspective of county growth 1830 1970: Gainesville, Fla., University of Florida, College of Business Administration, Bureau of Economic and Business Research, $211 \mathrm{p}$.

Dykes, G.M., and Conlon, W.J., 1989, Use of membrane technology in Florida: American Water Works Association Journal, v. 81, no. 11, p. 43-46 [Also available at https://doi.org/10.1002/j.1551-8833.1989.tb03305.x.]

Felton, R., 2019, Should we break our drinking water habit?: Consumer Reports, v 84, no. 11, p 36-47.

Ferguson, J.F., 2016, Southwest Florida Water Management District 2015 Estimated Water Use Report: Brooksville, Fla., Southwest Florida Water Management District, 224 p. [Also available at https://www.swfwmd.state.fl.us/sites/ default/files/medias/documents/EWUR-2015.pdf.]

Fernald, E.A., and Patton, D.J., eds., 1984, Water resource atlas of Florida: Tallahassee, Fla., Florida State University, Institute of Science and Public Affairs, 291 p.

Fernald, E.A., and Purdum, E.D., eds., 1992, Atlas of Florida: Tallahassee, Fla., Florida State University, Institute of Science and Public Affairs, $280 \mathrm{p}$.

Fernald, E.A., and Purdum, E.D., eds., 1998, Water resource atlas of Florida: Tallahassee, Fla., Florida State University, Institute of Science and Public Affairs, 312 p.

Florida Department of Agriculture and Consumer Services, 2016, Florida agriculture by the numbers 2015: Tallahassee, Fla., Division of Marketing and Development, FDACSP-01304, April 2016, 180 p. [Also available at https://www. freshfromflorida.com/Agriculture-Industry/Florida-Agriculture-Overview-and-Statistics.]

Florida Department of Agriculture and Consumer Services, 2017, Florida agriculture by the numbers 2016: Tallahassee, Fla., Division of Marketing and Development, FDACSP-01304, July 2017, 180 p. [Also available at https://www. freshfromflorida.com/Agriculture-Industry/Florida-Agriculture-Overview-and-Statistics.]
Florida Department of Environmental Protection, 2006, 2005 Reuse inventory: Tallahassee, Fla., Florida Department of Environmental Protection, Water Reuse Program, 21 p.

Florida Department of Environmental Protection, 2011, 2010 Reuse inventory: Tallahassee, Fla., Florida Department of Environmental Protection, Water Reuse Program, May 2011, 24 p.

Florida Department of Environmental Protection, 2016, 2015 Reuse inventory: Tallahassee, Fla., Florida Department of Environmental Protection, Water Reuse Program, May 2016, 25 p.

Florida Department of Environmental Regulation, 1990, Drinking water standards, monitoring, and reporting: Tallahassee, Fla., chap. 17-550, 48 p.

Florida Department of Environmental Regulation, 1991, Domestic wastewater facilities: Tallahassee, Fla., chap. $17-600,70 \mathrm{p}$.

Florida State University, 2017, Florida statewide averaged precipitation data: Tallahassee, Fla., Florida Climate Center, Office of the State Climatologist, accessed April 5, 2017, and September 12, 2018, at https://climatecenter.fsu.edu/ products-services/data/statewide-averages/precipitation.

Friedman, K.R., and Heaney, J.P., 2009, Water loss management-Conservation option in Florida's urban water systems: Florida Water Resources Journal, August 2009, p. 24-32. [Also available at http://fwrj.com/techarticles/0809\%20FWRJ\%20tech1.pdf.]

Gale Group, 2013, Industrial report: Farmington Hills, Mi., The Gale Group, Inc., accessed May 2013 at http://business. highbeem.com/industry-reports/mining/water-well-drilling.

Golf Course Superintendents Association of America, 2009, Golf course environmental profile-Volume II. Water use and conservation practices on U.S. golf courses: The Environmental Institute for Golf and Toro Foundation, 49 p. [Also available at https://gcsanc.com/wp-content/ uploads/2016/12/golf-course-environmental-profile-wateruse-report4.pdf.]

Harmon, J., 2016, South Florida Water Management District 2014 estimated water use report: West Palm Beach, Fla., South Florida Water Management District, Water Supply Bureau, 17 p. [Also available at https://www.sfwmd. gov/sites/default/files/documents/2014_est_water_use_ report.pdf.]

Harmon, J., Kennedy, N., Kraft, N., and Caneja, E., 2017, South Florida Water Management District 2015 estimated water use report: West Palm Beach, Fla., South Florida Water Management District, Water Supply Bureau, 34 p. [Also available at https://www.sfwmd.gov/sites/default/ files/documents/2015_est_water_use_report.pdf.] 
Hughes, G.H., 1975, Perspective on use of freshwater for cooling systems of thermoelectric power plants in Florida: U.S. Geological Survey Water-Resources Investigation 43-75, $30 \mathrm{p}$. [Also available at https://doi. org/10.3133/wri7543.]

Hutson, S.S., Barber, N.L., Kenny, J.F., and others, 2004, Estimated use of water in the United States in 2000: U.S. Geological Survey Circular 1268, 46 p. [Also available at https://doi.org/10.3133/cir1268.]

Izuno, F.T., and Haman, D.Z., 1987, Basic irrigation terminology: Gainesville, Fla., University of Florida, Institute of Food and Agricultural Sciences, Agricultural Engineering Fact Sheet AE-66, 4 p.

Kendall, M.G., 1938, A new measure of rank correlation: Biometricka, vol. 30, p. 81-93.

Kenny, J.F., Barber, N.L., Hutson, S.S., Linsey, K.S., Lovelace, J.K., and Maupin, M.A., 2009, Estimated use of water in the United States in 2005: U.S. Geological Survey Circular 1344, 52 p. [Also available at https://pubs.usgs.gov/circ/1344/.]

Knochenmus, L.A., and Swenson, E.S., 1996, Assessment of the fresh- and brackish-water resources underlying Dunedin and adjacent areas of northern Pinellas County, Florida, 1996: U.S. Geological Survey Water-Resources Investigations Report 96-4164, 47 p. [Also available at https://doi.org/10.3133/wri964164.]

Leach, S.D., 1978, Source, use, and disposition of water in Florida, 1975: U.S. Geological Survey Water-Resources Investigation 78-17, $90 \mathrm{p}$. [Also available at https://doi.org/10.3133/wri7817.]

Leach, S.D., 1983, Source, use, and disposition of water in Florida, 1980: U.S. Geological Survey Water-Resources Investigations 82-4090, $337 \mathrm{p}$. [Also available at https://doi.org/10.3133/wri824090.]

Leach, S.D., and Healy, H.G., 1980, Estimated water use in Florida, 1977: U.S. Geological Survey Water-Resources Investigations Report 79-112, 76 p. [Also available at https://doi.org/10.3133/wri79112.]

Lovelace, J.K., 2009a, Methods of estimating water withdrawals for aquaculture in the United States, 2005: U.S. Geological Survey Scientific Investigations Report 2009-5042, 13 p. [Also available at https://pubs. usgs.gov/sir/2009/5042/.]

Lovelace, J.K., 2009b, Method for estimating water withdrawals for livestock in the United States, 2005: U.S. Geological Survey Scientific Investigations Report 2009-5041, 7 p. [Also available at https://pubs.usgs.gov/sir/2009/5041/.]
MacKichan, K.A., 1951, Estimated use of water in the United States, 1950: U.S. Geological Survey Circular 115, 13 p. [Also available at https://doi.org/10.3133/cir115.]

MacKichan, K.A., 1957, Estimated use of water in the United States, 1955: U.S. Geological Survey Circular 398, 18 p. [Also available at https://doi.org/10.3133/cir398.]

MacKichan, K.A., and Kammerer, J.C., 1961, Estimated use of water in the United States, 1960: U.S. Geological Survey Circular 456, 44 p. [Also available at https://doi.org/10.3133/cir456.]

Marella, R.L., 1988, Water withdrawals, use, and trends in Florida, 1985: U.S. Geological Survey Water-Resources Investigations Report 88-4103, 43 p. [Also available at https://doi.org/10.3133/wri884103.]

Marella, R.L., 1992, Water withdrawals, use, and trends in Florida, 1990: U.S. Geological Survey Water-Resources Investigations Report 92-4140, 38 p. [Also available at https://pubs.er.usgs.gov/publication/wri924140.]

Marella, R.L., 1994, Estimated discharge of treated wastewater in Florida, 1990: U.S. Geological Survey Open-File Report 93-364, 53 p. [Also available at https://doi.org/10.3133/ofr93364.]

Marella, R.L., 1999, Water withdrawals, use, discharge, and trends in Florida, 1995: U.S. Geological Survey Water-Resources Investigations Report 99-4002, 90 p. [Also available at https://doi.org/10.3133/wri994002.]

Marella, R.L., 2004, Water withdrawals, use, discharge, and trends in Florida, 2000: U.S. Geological Survey Scientific Investigations Report 2004-5151, 136 p. [Also available at https://doi.org/10.3133/sir20045151.]

Marella, R.L., 2009, Water withdrawals, use, and trends in Florida, 2005: U.S. Geological Survey Scientific Investigations Report 2009-5125, 50 p. [Also available at https://doi.org/10.3133/sir20095125.]

Marella, R.L., 2014, Water withdrawals, use, and trends in Florida, 2010: U.S. Geological Survey Scientific Investigations Report 2014-5088, 59 p. [Also available at https://doi.org/10.3133/sir20145088.]

Marella, R.L., 2015, Water withdrawals in Florida, 2012: U.S. Geological Survey Open-File Report 2015-1156, 10 p. [Also available at https://doi.org/10.3133/ofr20151156.]

Marella, R.L., and Dixon, J.F., 2015, Agricultural irrigated land-use inventory for Jackson, Calhoun, and Gadsden Counties Florida, and Houston County Alabama, 2014: U.S. Geological Survey Open-File Report 2015-1170, 14 p. [Also available at https://doi.org/10.3133/ ofr20151170.] 
Marella, R.L. and Dixon, J.F., 2018, Data tables summarizing the source-specific estimated water withdrawals in Florida by water source, category, county, and water management district, 2015: U.S. Geological Survey data release, https://doi.org/10.5066/F7N29W5M.

Marella, R.L., Dixon, J.F., and Berry, D.R., 2016, Agricultural irrigated land-use inventory for the counties in the Suwannee River Water Management District in Florida, 2015: U.S. Geological Survey Open-File Report 2016-1111, 18 p. [Also available at https://doi. org/10.3133/ofr20161111.]

Marella, R.L., Dixon, J.F., and Berry, D.R., 2017, GIS data and tables pertaining to the agricultural irrigated land-use inventory for Escambia, Santa Rosa, and Okaloosa Counties in Florida, 2016: U.S. Geological Survey data release, https://doi.org/10.5066/F7BK19MR.

Maupin, M.A., Kenny, J.F., Hutson, S.S., Lovelace, J.K., Barber, N.L., and Linsey, K.S., 2014, Estimated use of water in the United States in 2010: U.S. Geological Survey Circular 1405, 56 p. [Also available at https://doi.org/10.3133/cir1405.]

McPherson, B.F., and Hammett, K.M., 1991, Tidal rivers of Florida, in Livingston, R.J., ed., The rivers of Florida: New York, Springer-Verlag, Ecological Studies, v. 83, p. 31-46.

Miller, J.A., 1990, Ground water atlas of the United States-Segment 6, Alabama, Florida, Georgia, and South Carolina: U.S. Geological Survey Hydrologic Investigation Atlas 730-G, 28 p. [Also available at https://doi. org/10.3133/ha730G.]

Mulkey, D., and Clouser, R.L., 1990, Agriculture, chap. 7 of Denslow, D.A., Pierce, A.C., and Shermyen, A.H., eds., The economy of Florida: Gainesville, Fla., University of Florida, Bureau of Economic and Business Research, p. 129-151.

Murray, C.R., 1968, Estimated use of water in the United States, 1965: U.S. Geological Survey Circular 556, 53 p. [Also available at https://doi.org/10.3133/cir556.]

Murray, C.R., and Reeves, E.B., 1972, Estimated use of water in the United States, 1970: U.S. Geological Survey Circular 676, 37 p. [Also available at https://doi.org/10.3133/cir676.]

Murray, C.R., and Reeves, E.B., 1977, Estimated use of water in the United States, 1975: U.S. Geological Survey Circular 765, 37 p. [Also available at https://doi.org/10.3133/cir765.]

Nelson, M., 2006, No longer on paper, St. Joe builds new Florida coastline: Associated Press, Sept. 17, 2006, accessed July 24, 2019, at https://www.ocala.com/news/20060917/ no-longer-on-paper-st-joe-builds-new-florida-coastline.

Pride, R.W., 1973, Estimated use of water in Florida, 1970: Tallahassee, Fla., Florida Bureau of Geology Information Circular 83, $31 \mathrm{p}$.
Pride, R.W., 1975, Estimated water use in Florida, 1965 ( $2 \mathrm{~d}$ ed.): Tallahassee, Fla., Florida Bureau of Geology Map Series 36,1 sheet.

Rayer, S., and Wang, Y., 2018, Projections of Florida Population by County, 2020-2045, with estimates for 2017: Gainesville, Fla., University of Florida, Bureau of Economic and Business Research, v. 51, Bulletin 180, January 2018, 9 p. [Also available at https://www.bebr.ufl.edu/sites/default/files/Research $\% 20$ Reports/projections_2018.pdf.]

Renken, R.A., 1998, Ground water atlas of the United States-Segment 5, Arkansas, Louisiana, Mississippi: U.S. Geological Survey Hydrologic Investigation Atlas 730-F, 28 p. [Also available at https://doi.org/10.3133/ ha730F.]

Renken, R.A., Dixon, J.F., Koehmstedt, J., Ishman, S., Lietz, A.C., Marella, R.L., Telis, P., Rodgers, J., and Memberg, S., 2005, Impact of anthropogenic development on coast ground-water hydrology in southern Florida, 1900-2000: U.S. Geological Survey Circular 1275, 77 p. [Also available at https://pubs.usgs.gov/circ/2005/circ1275/.]

Reese, R.S., 2006, Review of aquifer storage and recovery performance in the Upper Floridan aquifer in southern Florida: U.S. Geological Survey Fact Sheet 2006-3126, 2 p. [Also available at https://doi.org/10.3133/fs20063126.]

Seaber, P.R., Kapinos, F.P., and Knapp, G.L., 1984, State hydrologic unit maps: U.S. Geological Survey Open-File Report 84-708, 63 p. [Also available at https://doi.org/10.3133/ofr84708.]

Smajstrla, A.G., 1990, Agricultural field scale irrigation requirements simulation model (AFSIRS): Technical manual, version 5.5: Gainesville, Fla., University of Florida Agricultural Engineering Department, 52 p.

Smajstrla, A.G., Boman, B.J., Clark, G.A., Haman, D.Z., Harrison, D.S., Izuno, F.T., and Zazueta, F.S., 1988, Efficiencies of Florida agricultural irrigation systems: Gainesville, Fla., University of Florida Institute of Food and Agricultural Sciences, Bulletin 247, 15 p.

Smajstrla, A.G., and Zazueta, F.S., 1995, Estimating crop irrigation requirements for irrigation system design and consumptive use permitting: Gainesville, Fla., University of Florida, Agricultural and Biological Engineering Department, Document AE257, 4 p.

Smajstrla, A.G., and others, 1993, Micro irrigation in Florida-Systems, acreage and cost: Gainesville, Fla., University of Florida Institute of Food and Agricultural Sciences, Bulletin 276, 12 p.

Solley, W.B., Chase, E.B., and Mann, W.B., 1983, Estimated use of water in the United States in 1980: U.S. Geological Survey Circular 1001, 56 p. [Also available at https://doi.org/10.3133/cir1001.] 
Solley, W.B., Merk, C.F., and Pierce, R.R., 1988, Estimated use of water in the United States in 1985: U.S. Geological Survey Circular 1004, 82 p. [Also available at https://doi.org/10.3133/cir1004.]

Solley, W.B., Pierce, R.R., and Perlman, H.A., 1993, Estimated use of water in the United States in 1990: U.S. Geological Survey Circular 1081, 76 p. [Also available at https://doi.org/10.3133/cir1081.]

Solley, W.B., Pierce, R.R., and Perlman, H.A., 1998, Estimated use of water in the United States in 1995: U.S. Geological Survey Circular 1200, 78 p. [Also available at https://doi.org/10.3133/cir1200.]

South Florida Water Management District, 1990, Desalination - An additional water source for South Florida: West Palm Beach, Fla., South Florida Water Management District, Office of Communications, PIO 276290 5M, 4 p.

Southwest Florida Water Management District, 1992, AGMOD, Agricultural water use model, Version 2.0: Brooksville, Fla., Southwest Florida Water Management District, $51 \mathrm{p}$.

St. Johns River Water Management District, 2016, 2015 Survey of estimated annual water use for the St. Johns River Water Management District: Palatka, Fla., St. Johns River Water Management District Technical Fact Sheet SJ2016-FS3, 294 p. [Also available at https://www.sjrwmd.com/documents/technical-reports/ fact-sheets/.]

U.S. Census Bureau, 1992, County business patterns, 1990, Florida: Washington D.C., U.S. Department of Commerce, Bureau of the Census, $215 \mathrm{p}$.

U.S. Census Bureau, 1993, 1990 Census of housing, detailed housing characteristics-Florida: Washington, D.C., U.S. Department of Commerce, Bureau of the Census, Ch-2-11, $793 \mathrm{p}$.

U.S. Census Bureau, 2012, County business patterns, 2010, Florida: Washington D.C., U.S. Department of Commerce, Bureau of the Census, CB1000A1, accessed July, 12, 2017, at http://www2.census.gov/econ2010/CB/sector00/ CB1000A1.zip.

U.S. Census Bureau, 2016, Annual estimates of the resident population for the United States, regions, States, and Puerto Rico, April 2010 to July 2016: Washington D.C., U.S. Department of Commerce, Bureau of the Census, Population Division, 2 p., accessed July 12, 2017, at https:// factfinder.census.gov/faces/nav/jsf/pages/index.xhtml.

U.S. Census Bureau, 2017, County business patterns, 2015, Florida: Washington D.C., U.S. Department of Commerce, Bureau of the Census, CB1500A11, accessed July, 12, 2017, at http://www2.census.gov/econ2015/CB/sector00/ CB1500A11.zip.
U.S. Department of Agriculture, 2009, 2007 Census of Agriculture - Florida State and county data: Washington D.C., U.S. Department of Agriculture, National Agricultural Statistics Service, Geographic Area Series, part 9 [AC-07-A-9], v. 1, 485 p. [Also available at https://www.nass.usda.gov/Publications/AgCensus/2007/ index.php.]

U.S. Department of Agriculture, 2014, 2012 Census of Agriculture - Florida State and county data: Washington D.C., U.S. Department of Agriculture, National Agricultural Statistics Service, Geographic Area Series, part 9 [AC-12-A-9], v. 1, 494 p. [Also available at https://www.nass.usda.gov/Publications/AgCensus/2012/ index.php.]

U.S. Energy Information Administration, 2018, State Energy Data System - 1960-2016, Florida: Accessed June 19, 2019, at https://www.eia.gov/state/seds/seds-datacomplete.php?sid=FLConsumption.

U.S. Energy Information Administration, n.d., Glossary: U.S. Energy Information Administration website accessed July 24, 2019, at https://www.eia.gov/tools/ glossary/?id=electricity.

U.S. Geological Survey, 1975, State of Florida hydrologic unit map, 1974: U.S. Geological Survey, 1 sheet, scale 1:500,000. [Also available at https://doi.org /10.3133/hu9.]

U.S. Geological Survey, 2018, Advance release of the 1971-2015 aggregates data: U.S. Geological Survey Minerals Yearbook 2015, v. II, accessed July 24, 2019, at https://www.usgs.gov/centers/nmic/state-minerals-statisticsand-information.

U.S. Soil Conservation Service, 1970, Irrigation water requirement (Blaney-Criddle revised): Washington D.C., U.S. Department of Agriculture, Soil Conservation Service, Technical Release 21, $88 \mathrm{p}$.

U.S. Soil Conservation Service, 1982, Florida irrigation guide: Gainesville, Fla., U.S. Department of Agriculture, Soil Conservation Service, 300 p.

University of Florida, 2015a, Florida estimates of population, 2015: Gainesville, Fla., University of Florida, Bureau of Economic and Business Research, April 15, 2015, 56 p. [Also available at https://www.bebr. ufl.edu/population/data.]

University of Florida, 2015b, Households and average household size in Florida, April 1, 2015: Gainesville, Fla., University of Florida, Bureau of Economic and Business Research, Florida Population Studies, v. 49, bulletin 173, 6 p. [Also available at https://www.bebr.ufl.edu/sites/ default/files/Research\%20Reports/households_2015.pdf.] 
Vecchioli, J., and Foose, D.W., 1985, Florida ground-water resources, in The national water summary, 1984-

Hydrologic events, selected water quality trends and ground-water resources: U.S. Geological Survey Water-Supply Paper 2275, p. 173-178. [Also available at https://doi.org/10.3133/wsp2275.]

Verdi, R.J., Tomlinson, S.A., and Marella, R.L., 2006, The drought of 1998-2002 - Impacts of Florida's hydrology and landscape: U.S. Geological Survey Circular 1295, 34 p. [Also available at https://doi.org/10.3133/cir1295.]
Visit Florida, 2018, Florida-fact, 2018: Accessed June 20, 2018, at www.visitfloridamediablog.com/home/ florida-fact/research.

White, J.K., and van Blokland, P.J., 2006, Trends in Florida citrus with emphasis on Indian River, St. Lucie, Martin, and Palm Beach Counties: Gainesville, Fla., University of Florida, Food and Resource Economics Department, EDIS FE636, 9 p. [Also available at https://ufdcimages.uflib.ufl. edu/IR/00/00/20/44/00001/FE63600.pdf.] 


\section{Glossary}

A

agricultural use Includes water used for agricultural irrigation and nonirrigation purposes. Irrigation water use includes the artificial application of water on lands to assist in the growing of crops, plants, and grasses. Nonirrigation water use includes water used for livestock, fish farming, and other farm needs. Livestock water use includes water used for stock watering, feedlots, and dairy operations. The water can be obtained from a public supply or be self-supplied and is applied through a micro, flood, or sprinkler irrigation system.

application rate A calculated value commonly used to estimate the amount of water that must be applied to meet the evapotranspiration (ET) needs of a specific crop for optimum growth (Smajstrla and Zazueta, 1995). The application rate is usually generated from an irrigation demand model and is normally reported in inches per acre (Smajstrla, 1990; Southwest Florida Water Management District, 1992). This value usually includes the water needed to overcome irrigation system inefficiencies and system losses (U.S. Soil Conservation Service, 1970, 1982). May also be referred to as an irrigation crop coefficient.

\section{B}

brackish water Water that has dissolved-solids concentrations between 500 and 10,000 milligrams per liter $(\mathrm{mg} / \mathrm{L})$ (Knochenmus and Swenson, 1996). Brackish water needs some form of treatment before it meets potable standards set by the Florida Department of Environmental Protection and can be made available for human consumption (Florida Department of Environmental Regulation, 1990). Brackish water can be used for irrigation purposes without treatment, with some limitations. This water is classified as saline under the U.S. Geological Survey guidelines for this report, however, the Florida water management districts still classify this water as brackish freshwater.

\section{C}

combined cycle Refers to a power generating system that produces both electricity and heat from a single heat source (Diehl and others, 2013). The waste heat is then used to generate steam which turns a steam turbine-generator to produce additional electricity resulting in significantly more efficient power production (U.S. Energy Information Administration, n.d.).

commercial use Water for motels, hotels, restaurants, office buildings, commercial facilities, and civilian and military institutions. The water may be obtained from a public supply or be self-supplied.

community water system A public-water system that serves at least 15 service connections used by year-round residents or regularly serves at least 25 year-round residents (Florida Department of Environmental Regulation, 1990).

consumptive use That part of water withdrawn that is evaporated, transpired, incorporated into products or crops, consumed by humans or livestock, or otherwise removed from the immediate water environment. Sometimes called water consumed or water depleted.

cooling pond Usually a manmade water body used by power plants for heat exchange of once-through cooling water generated by steam condensers. The water levels in the pond are usually maintained by rainfall or augmented by pumping (withdrawal of) water from another source (fresh, saline, or reclaimed) as some water is lost (consumed) through evaporation. See cooling water or once-through cooling water.

cooling tower A large tower or stack that is used for heat exchange of once-through cooling water generated by steam condensers. Hot water from the plant is sprayed into the top of the tower and exchanges heat with the passing air as it falls. The water is then collected at the bottom of the tower and used again. A small amount of water is lost (consumed) through evaporation in this process. See cooling water or once-through cooling water. 
cooling water Water used for cooling purposes by electric generators, steam condensers, large machinery or products at power or industrial plants. Water used for cooling purposes can be either fresh, saline, or reclaimed and may be used only once or recirculated multiple times. See cooling pond, cooling tower, or once-through cooling water.

\section{D}

desalination The removal of salts from highly mineralized water. Desalination is primarily used for public-supply water to ensure that it meets Florida Department of Environmental Protection secondary drinking-water standards. The primary types of desalination used in Florida are (1) distillation, (2) electrodialysis processes, and (3) reverse osmosis processes (Buros, 1989; South Florida Water Management District, 1990). The reverse osmosis process is the type most commonly used in Florida, followed by electrodialysis (Dykes and Conlon, 1989). In addition to these three desalination processes, many public suppliers also dilute or blend nonpotable or brackish water with fresher water to produce potable water. Also see reverse osmosis.

dewatering The deliberate attempt to lower the groundwater level in or below land surface for selected purposes, such as agricultural, construction, mining, or other activities. For mining operations, dewatering usually is accomplished by pumping the water out of the ground and discharging to a surface-water body. However, some dewatering involves gravity feeding water from the surficial aquifer system into a deeper aquifer (usually the Floridan aquifer system) through recharge wells (Campbell, 1986).

domestic use Water for normal household purposes, such as drinking, food preparation, bathing, washing clothes and dishes, flushing toilets, and other indoor uses. It also includes outdoor uses, such as car washing and watering household lawns and gardens. Domestic water use is sometimes referred to as residential water use. The water can be obtained from a public supply or be self-supplied.

\section{E}

evapotranspiration (ET) ET is the term used to define the amount of water needed to grow a healthy and productive plant. Evaporation is the change of water from liquid to vapor, and transpiration is the evaporation from plant leaves, and both occur in response to weather (Smajstrla and Zazueta, 1995). Rainfall and irrigation must be sufficient to meet the crop's ET requirement.

\section{$\mathbf{F}$}

\section{flood irrigation (including}

seepage) Irrigation systems that control the water table with lateral supply ditches. These include open-field ditch systems (furrows), semi-closed conveyance systems, subsurface conduit systems, crown flood systems, and continuous (paddy) flood systems. The efficiencies of these flood irrigation systems range from 20 to 80 percent (Smajstrla and others, 1988); however, an average of 60 percent is commonly used for estimating water requirements. May also be referred to as subsurface irrigation.

freshwater Water that contains less than $1,000 \mathrm{mg} / \mathrm{L}$ of dissolved solids; generally, more than $500 \mathrm{mg} / \mathrm{L}$ is considered undesirable for drinking and many industrial uses.

Generally, freshwater is considered potable.

\section{G}

gigawatthour (GWh) A measure of electricity, 1 billion watt hours.

groundwater That part of the subsurface water that is in the saturated zone (a zone in which all voids are filled with water).

\section{H}

hydroelectric power generation The use of water in the generation of electricity at plants where the turbine generators are driven by falling water. This is considered an instream use of water.

\section{I}

industrial use Water used for industrial purposes such as fabricating, processing, washing, and cooling; includes such industries as steel, chemical and allied products, paper and allied products, mining, and petroleum refining. The water can be obtained from a public supply or be self-supplied.

instream use Water use taking place within a stream channel for such purposes as hydroelectric power generation, navigation, water-quality improvement, fish and wildlife propagation, and recreation. Instream use is sometimes referred to as nonwithdrawal use or in-channel use. 


\section{M}

micro irrigation Irrigation systems that are low-pressure, low-flow-rate systems which distribute water through relatively small diameter pipes directly to, or very near, the soil surface, either above the ground, in discrete drops, continuous drops, small streams, mist, or sprays. These include drip systems, spray systems, jet systems, and bubbler systems. Micro irrigation systems may also be referred to as drip, low-pressure, or low-volume irrigation. The efficiencies of these micro irrigation systems range from 75 to 95 percent (Smajstrla and others, 1988, 1993); however, an average of 80 percent is commonly used for estimating water requirements.

mining use Water used for the extraction of minerals and liquids. Mining also includes water used for milling (such as crushing, screening, washing, and flotation), environmental purposes (such as dust control and wetland restoration or maintenance), material conveyance, dewatering, and domestic uses on the premises. Generally, most of the water used at a mining operation is self-supplied.

\section{N}

navigation use Water utilized as a means of commercial (and sometimes recreational) transportation. Includes water used to lift a vessel in a lock or maintain a navigable channel level. Navigational water use is considered a nonconsumptive instream use of water and is generally not measured.

net water use Water withdrawals plus or minus water transfers. In most counties, the net water use and water withdrawals are equal; however, in counties involved in water transfers (imports and exports), the net water use represents the actual amount of water used regardless of the amount of water withdrawn. In Florida, most water transfers occur in the public-supply category. Also see water transfers.

nonpotable water Water that is highly mineralized and needs some form of treatment before it meets standards set by the Florida Department of Environmental Protection and can be made available for human consumption (Florida Department of Environmental Regulation, 1990). In Florida, chloride and dissolved-solids concentrations in potable water must be less than or equal to
250 and $500 \mathrm{mg} / \mathrm{L}$, respectively. Nonpotable water exceeds these concentrations consistently or periodically and is either diluted with fresher water or treated through a desalination or filtration process to meet potable-water standards for public supply (see desalination). This water has been categorized as saline by the U.S. Geological Survey since 2010 but has remained within the freshwater category for the five Florida water management districts.

nontransient noncommunity water system A public-water system that is not a community water system and that regularly serves at least 25 of the same individuals during a 6-month period (Florida Department of Environmental Regulation, 1990).

\section{0}

onsite runoff Runoff collected from unused irrigation water or rainwater that is retained in a canal, ditch, pond, or impoundment on the user's fields or land. This water is typically used again for irrigation purposes or used to maintain water levels in lakes or ponds for aesthetic purposes. It may also be left to evaporate, percolate into the ground, receive treatment, and (or) be discharged to other surface-water bodies.

once-through cooling Fresh or saline water that is withdrawn from a river, stream or other water body (manmade or natural), or a well, passed through a steam condenser once, and then returned to the surface-water source some distance from the intake (Hughes, 1975). Once-through cooling water is used to exchange heat from the steam condensers to the cooler water. This method of cooling is commonly used in power production throughout Florida and usually results in no consumption.

other use Water used in Florida for such purposes as heating, cooling, irrigation (public-supplied only), lake augmentation, and other nonspecific uses. The water can be obtained from a public supply or be self-supplied.

\section{$\mathbf{P}$}

per capita use The average amount of water used per person during a standard time period, generally per day. For this report, two per capita estimates are calculated. Public-supply gross per capita is the total public-supply water withdrawn, divided by the total 
population served by public supply. Per capita water use computed in this manner includes water delivered for all uses of public-supply water (domestic, commercial, industrial, public uses, and other uses). Public-supply domestic per capita is calculated by dividing the deliveries to domestic use from public suppliers by the population served. Per capita use computed in this manner represents the amount of water used at the household level (both indoor and outdoor), because it excludes all other uses of public-supply water (commercial, industrial, public uses, or other uses).

population The number of people that live in a State (or county) who consider that State (or county) their permanent residence. This number is usually estimated by the U.S. Bureau of Census or some other Federal or State agency delegated to compile such data on a designated timeframe. College students, military personnel, and inmates of penal institutions are counted as permanent residents. According to this definition, tourist, seasonal, or part-time residents are considered part of the nonresident population. All population values presented in this report represent the resident population, unless otherwise noted.

potable water Water that meets the quality standards set by the Florida Department of Environmental Protection (Florida Department of Environmental Regulation, 1990). Potable water is considered safe for human consumption and is often referred to as drinking water. In Florida, chloride and dissolved-solids concentrations in potable water must be less than or equal to 250 and $500 \mathrm{mg} / \mathrm{L}$, respectively. Freshwater that exceeds these chloride and dissolved-solids concentrations is often referred to as nonpotable or brackish water and is either diluted with fresher water or treated through a desalination or filtration process to meet potable-water standards for public supply.

power generation use Water used in the process of electric power generation by a thermoelectric or hydroelectric facility.

public supply Water withdrawn by public or private water suppliers and delivered to users who do not supply their own water. Water suppliers provide water for a variety of uses, such as domestic, commercial, industrial, thermoelectric power (domestic and cooling purposes), and public-water use. Any water system that serves more than 25 people or has 15 year-round service connections is considered a community public supplier (Florida Department of Environmental Regulation, 1990). For this report, public supply includes those systems that serve more than 400 people or withdraw more than 10,000 gallons per day.

public use Water provided from a public-water supply and used for such purposes as firefighting, street washing, and municipal parks and swimming pools. Public-water use also includes system losses during distribution, processing (including water discharge from desalination or lime-softening facilities), or transmission between wholesalers. Public-water use is sometimes referred to as utility use.

\section{$\mathbf{R}$}

recirculated water Water that is used more than once before it returns to the natural hydrologic system or is discharged into a wastewater system. Also referred to as recycled water.

reclaimed wastewater Water that has received primary, secondary, or advanced treatment and is released from a wastewater facility after treatment for use again through a reuse system.

recreational-landscape irrigation use The application of water on lands to assist in growing turfgrass (primarily grasses associated with golf courses) and landscape vegetation for commercial lawns, recreation areas, common areas, and other grasses, as well as vegetation in nonagricultural areas, such as cemeteries, playgrounds, and school grounds. This category also includes water withdrawn and used for aesthetic purposes (filling of nonagricultural lakes, ponds, and fountains).

residential use See domestic use.

reuse system The deliberate application of reclaimed wastewater for a beneficial or other useful purpose. Reuse may encompass landscape irrigation (such as golf courses, cemeteries, highway medians, parks, playgrounds, schoolyards, nurseries, and residential properties), agricultural irrigation (such as food and fruit crops, wholesale nurseries, sod farms, and pasture grass), aesthetic uses, groundwater recharge, environmental enhancement of surface water and wetland restoration, fire protection, cooling water, and other useful purposes. 
reverse osmosis The process of removing salts from water by use of a membrane. With reverse osmosis, the product water passes through a fine membrane that the salts are unable to pass through, and the salt waste (brine) is removed and disposed. This differs from electrodialysis in which the salts are extracted from the feed water by using a membrane with an electrical current to separate the ions. During electrodialysis, the positive ions flow through one membrane while the negative ions flow through a different membrane, leaving freshwater as the end product. In this report, reverse osmosis includes any water treated through both reverse osmosis and electrodialysis, and any water diluted or blended with fresher water that was used to obtain potable water. Also see desalination.

\section{S}

saline water Water that contains more than $1,000 \mathrm{mg} / \mathrm{L}$ of dissolved solids.

self-supplied water Water withdrawn by an individual user (such as private domestic household or a farmer) or by a facility (such as a factory or powerplant) for a use. A self-supplied user generally, but not always, does not receive any water from a public-supply water system.

sprinkler irrigation A pressurized irrigation system in which water is distributed through pipes to the field and applied through a variety of sprinkler heads or nozzles. Pressure is used to spread water droplets above the crop canopy to simulate rainfall (Izuno and Haman, 1987). These systems include portable and traveling guns, solid or permanent fixtures (overhead or pop ups), center pivots, linear-move, and periodic-moving systems. The efficiencies of these sprinkler irrigation systems range from 15 to 85 percent (Smajstrla and others, 1988); however, an average of 70 percent is commonly used for estimating water requirements. Also referred to as overhead irrigation.

\section{$\mathbf{T}$}

thermoelectric-power water use Water used in the process of generating electricity with steam-driven turbine generators using fossil fuel (coal, oil, natural gas, or biomass), geothermal, or nuclear energy sources (Maupin and others, 2014). transient noncommunity water system A public-water system that provides piped water for human consumption to at least 15 service connections or that serves at least 25 individuals at least 60 days out of the year but is not a community water system. The difference between a community water system and a noncommunity water system is that the former serves inhabitants, whereas the latter serves transients or nonresidents who otherwise do not inhabit the building served by the system (Florida Department of Environmental Regulation, 1990).

\section{W}

wastewater A combination of liquid and water-borne pollutants from residential or commercial buildings, industrial plants, and institutions. Wastewater receives treatment (primary, secondary, or advanced) before it is released back to the environment as treated effluent (Florida Department of Environmental Regulation, 1991). Treated effluent can be directly discharged into surface-water bodies (including marshes or wetlands), disposed of in the ground either by injection or seepage (including absorption beds, injection wells, drainfields, percolation ponds, rapid infiltration basins, spray fields, and land application systems), or reused in some form or way (including irrigation, cooling water, industrial processes, and others) (Marella, 1994).

water transfer Artificial conveyance of water from one area to another across a political or hydrological boundary. Also referred to as an import or export of water from one basin or county to another.

water use In a restrictive sense, the term refers to water that is actually used for a specific purpose, such as domestic use, irrigation, or industrial processing. More broadly, water use pertains to human interaction with, and influence on, the hydrologic cycle and includes elements such as water withdrawals, deliveries, consumptive use, wastewater releases, reclaimed wastewater, return flow, and instream use.

withdrawal Water removed from the ground or diverted from a surface-water source. The amount of water withdrawn may not equal the amount of water used because of water transfers or the recirculation or recycling of the same water. For example, a powerplant may use the same water multiple times but withdraw a substantially different amount. 


\section{Glossary References Cited}

Buros, O.K., 1989, Desalting practices in the United States: American Water Works Association Journal, v. 81, no. 11, p. 38-42. [Also available at https://doi.org/10.1002/j.1551-8833.1989.tb03304.x.]

Campbell, K.M., 1986, The industrial minerals of Florida: Tallahassee, Fla., Florida Bureau of Geology Information Circular 102, 94 p.

Diehl, T.H., and Harris, M.A., 2014, Withdrawal and consumption of water by thermoelectric power plants in the United States, 2010: U.S. Geological Survey Scientific Investigations Report 2014-5184, 28 p. [Also available at https://dx.doi.org/10.3133/sir20145184.]

Diehl, T.H., Harris, M.A., Murphy, J.C., Hutson, S.S., and Ladd, D.E., 2013, Methods for estimating water consumption for thermoelectric power plants in the United States: U.S. Geological Survey, Scientific Investigations Report 2013-5188, 78 p. [Also available at https://doi.org/10.3133/sir20135188.]

Dykes, G.M., and Conlon, W.J., 1989, Use of membrane technology in Florida: American Water Works Association Journal, v. 81, no. 11, p. 43-46. [Also available at https://doi.org/10.1002/j.1551-8833.1989.tb03305.x.]

Florida Department of Environmental Regulation, 1990, Drinking water standards, monitoring, and reporting: Tallahassee, Fla., chap. 17-550, 48 p.

Florida Department of Environmental Regulation, 1991, Domestic wastewater facilities: Tallahassee, Fla., chap. 17-600, 70 p.

Hughes, G.H., 1975, Perspective on use of freshwater for cooling systems of thermoelectric power plants in Florida: U.S. Geological Survey Water-Resources Investigation 43-75, 30 p. [Also available at https://doi. org/10.3133/wri7543.]

Izuno, F.T., and Haman, D.Z., 1987, Basic irrigation terminology: Gainesville, Fla., University of Florida, Institute of Food and Agricultural Sciences, Agricultural Engineering Fact Sheet AE-66, 4 p.

Knochenmus, L.A., and Swenson, E.S., 1996, Assessment of the fresh- and brackish-water resources underlying Dunedin and adjacent areas of northern Pinellas County, Florida, 1996: U.S. Geological Survey Water-Resources Investigations Report 96-4164, 47 p. [Also available at https://doi.org/10.3133/wri964164.]
Marella, R.L., 1994, Estimated discharge of treated wastewater in Florida, 1990: U.S. Geological Survey Open-File Report 93-364, 53 p. [Also available at https://doi.org/10.3133/ofr93364.]

Maupin, M.A., Kenny, J.F., Hutson, S.S., Lovelace, J.K., Barber, N.L., and Linsey, K.S., 2014, Estimated use of water in the United States in 2010: U.S. Geological Survey Circular 1405, 56 p. [Also available at https://doi.org/10.3133/cir1405.]

Smajstrla, A.G., 1990, Agricultural field scale irrigation requirements simulation model (AFSIRS): Gainesville, Fla., University of Florida Agricultural Engineering Department, technical manual, version 5.5, $52 \mathrm{p}$.

Smajstrla, A.G., and others, 1988, Efficiencies of Florida agricultural irrigation systems: Gainesville, Fla., University of Florida Institute of Food and Agricultural Sciences, Bulletin 247, 15 p.

Smajstrla, A.G., and others, 1993, Micro irrigation in Florida-Systems, acreage and cost: Gainesville, Fla., University of Florida Institute of Food and Agricultural Sciences, Bulletin 276, 12 p.

Smajstrla, A.G., and Zazueta, F.S., 1995, Estimating crop irrigation requirements for irrigation system design and consumptive use permitting: Gainesville, Fla., University of Florida, Agricultural and Biological Engineering Department, Document AE257, 4 p.

South Florida Water Management District, 1990, Desalination-An additional water source for South Florida: West Palm Beach, Fla., South Florida Water Management District Office of Communications, PIO 276290 5M, 4 p.

Southwest Florida Water Management District, 1992, AGMOD, Agricultural water use model, Version 2.0: Brooksville, Fla., Southwest Florida Water Management District, $51 \mathrm{p}$.

U.S. Energy Information Administration, n.d., Glossary: U.S. Energy Information Administration website accessed July 24, 2019, at https:/www.eia.gov/tools/ glossary/?id=electricity.

U.S. Soil Conservation Service, 1970, Irrigation water requirement (Blaney-Criddle revised): Washington D.C., U.S. Department of Agriculture, Soil Conservation Service, Technical Release 21, 88 p.

U.S. Soil Conservation Service, 1982, Florida irrigation guide: Gainesville, Fla., U.S. Department of Agriculture, Soil Conservation Service, 300 p. 
For more information about this publication, contact

Director, Caribbean-Florida Water Science Center

U.S. Geological Survey

4446 Pet Lane, Suite 108

Lutz, FL 33559

(813) 498-5000

For additional information visit

https://www2.usgs.gov/water/caribbeanflorida/index.html

Publishing support provided by

Lafayette Publishing Service Center 


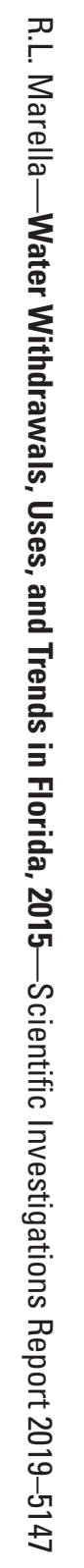

